\title{
Three-Dimensional Analysis of Future Groundwater Flow Conditions and Contaminant Plume Transport in the Hanford Site Unconfined Aquifer System: FY 1996 and 1997 Status Report
}

C. R. Cole

S. K. Wurstner

M. P. Bergeron

M. D. Williams

P. D. Thorne

December 1997

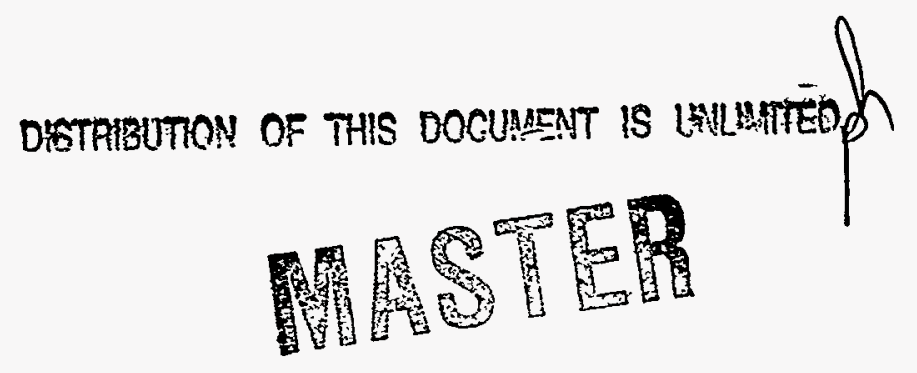

Prepared for

the U.S. Department of Energy

under Contract DE-AC06-76RLO 1830

Pacific Northwest National Laboratory

Richland, Washington 99352 


\section{DISCLAIMER}

This report was prepared as an account of work sponsored by an agency of the United States Government. Neither the United States Government nor any agency thereof, nor any of their employees, make any warranty, express or implied, or assumes any legal liabiity or responsibility for the accuracy, completeness, or usefulness of any information, apparatus, product, or process disclosed, or represents that its use would not infringe privately owned rights. Reference herein to any specific commercial product, process, or service by trade name, trademark, manufacturer, or otherwise does not necessarily constitute or imply its endorsement, recommendation, or favoring by the United States Government or any agency thereof. The views and opinions of authors expressed herein do not necessarily state or reflect those of the United States Government or any agency thereof. 


\section{DISCLAIMER}

Portions of this document may be illegible electronic image products. Images are produced from the best available original document. 


\section{Executive Summary}

A three-dimensional numerical model of groundwater flow and transport, based on the Coupled Fluid Energy, and Solute Transport (CFEST) code, was developed for the Hanford Site to support the Hanford Groundwater Project (HGWP), managed by Pacific Northwest National Laboratory. ${ }^{\text {(a) }}$ The model was developed to increase the understanding and better forecast the migration of several contaminant plumes being monitored by the HGWP, and to support the Hanford Site Composite Analysis for low-level waste disposal in the 200-Area Plateau.

Recent modeling efforts have focused on continued refinement of an initial version of the three-dimensional model developed in 1995 and its application to simulate future transport of selected contaminant plumes in the aquifer system. This version of the model was updated using a more current version of the CFEST code called CFEST96.

Prior to conducting simulations of contaminant transport with the three-dimensional model, a previous steady-state, two-dimensional model of the unconfined aquifer system was recalibrated to 1979 water-table conditions with a statistical inverse method implemented in the CFEST-INV computer code. The results of the recalibration were used to refine the three-dimensional conceptual model and to calibrate it with a conceptualization that preserves the two-dimensional hydraulic properties and knowledge of the aquifer's three-dimensional properties for the same 1979 water-table conditions. The transient behavior of the threedimensional flow model was also calibrated by adjusting model storage properties (specific yield) until transient water-table predictions approximated observed water-table elevations between 1979 and 1996.

Following the steady-state and transient-state calibrations, the three-dimensional model was applied to predict the future response of the water table to postulated changes in Hanford operations. Over about a 300-year period following elimination of wastewater discharges to the ground at the Site, the water table predicted by the model declines significantly and returns to near pre-Hanford water-table conditions that were estimated to exist in 1944. Model results show that over this period, the water table will drop as much as about $11 \mathrm{~m}$ in the 200-West Area and $10 \mathrm{~m}$ in the 200-East Area near B Pond. Model results of steady-

(a) Pacific Northwest National Laboratory is operated by Battelle for the U.S. Department of Energy under contract DE-AC06-76RLO 1830. 
state simulations compared favorably with overall water-table conditions estimated prior to Hanford Operations in 1944, except in two areas: 1) the area west of the 200-Area plateau, where higher predicted hydraulic heads reflect boundary conditions that consider the effect of increased irrigation from areas upgradient of the modeled region; and 2) the area north of Richland, where the model considered the hydraulic effect of the North Richland well field.

Flow modeling results also suggest that as water levels drop in the vicinity of central areas in the model where the basalt crops out above the water table, the saturated thickness of the unconfined aquifer greatly decreases and the aquifer may actually dry out. This thinning/drying of the aquifer is predicted to occur in the area between Gable Butte and the outcrop south of Gable Mountain, resulting in the northern area of the unconfined aquifer becoming hydrologically separated from the area south of Gable Mountain and Gable Butte. Therefore, flow from the 200-West Area and the northern half of the 200-East Area, which currently migrates through the gap between Gable Butte and Gable Mountain, will be effectively cut off in the next 200 to 300 years. In time, the overall water table (including groundwater mounds near the 200-East and -West Areas) will decline, and groundwater movement from the 200-Area plateau will shift to a dominantly west-to-easterly pattern of flow toward points of discharge along the Columbia River between the Old Hanford townsite and the Washington Public Power Supply System facility.

The FY 1997 effort includes three-dimensional model simulations of the existing tritium, iodine-129, technetium-99, uranium, and strontium-90 plumes originating from the 200-Area plateau. Each of the transport simulations was based on the predicted future transient-flow conditions and a high-resolution, finite-element grid was designed to resolve transport calculations in the areas of current and future contamination. The following conclusions were reached based on the simulations:

Tritium - Simulations of the tritium plume originating from the 200 Area predicted that the 200-East Area plume will continue to discharge along the Columbia River between the Old Hanford townsite and an area north of the 300 Area over a period of about 90 to 100 years until it completely discharges into the river and/or decays below detection limits. The tritium plume from the 200-West Area is predicted to migrate beneath the 200-East Area as it is reduced by dispersion and decay.

Iodine-129 - Predictions of the iodine-129 plume beneath the 200-East Area indicated that the plume will migrate toward and discharge into the Columbia River over a period of about 600 years. Over the period of migration, iodine-129 concentrations that are predicted to discharge into the river will decline slightly by 
the processes of dispersion and sorption. However, initial concentrations will not fall significantly below current levels because of the radionuclide's long half-life. The iodine-129 plume from the 200-West Area is predicted to migrate toward the 200-East Area as it is reduced by dispersion and sorption.

Technetium-99 - Transport modeling of the technetium-99 plume indicated that the current technetium-99 plumes in the 200-East and the 200-West Areas will continue to slowly migrate laterally from source locations in the 200 Areas to the Columbia River. The plumes in the 200-West Area decline to levels below regulatory concern as they migrate eastward toward the 200-East Area. The technetium-99 plume from the northern part of the 200-East Area is predicted to continue migrating northward through the gap between Gable Butte and Gable Mountain toward the Columbia River. However, concentration levels of the simulated plumes decline to below drinking water standards ( $900 \mathrm{pCi} / \mathrm{L})$ over a period of 100 years by the processes of dilution by infiltration and plume dispersion.

Uranium - Simulations of the uranium plume in the 200 Areas predicted that the current uranium plumes will not migrate significantly from current source locations in the 200 Area because uranium is adsorbed with a distribution coefficient $\left(\mathrm{K}_{d}\right)$ of $3.0 \mathrm{ml} / \mathrm{g}$. Concentration levels of the simulated plumes in the 200 Area will decline below regulatory concern over the next 50 years by the processes of dilution by infiltrating rainwater and plume dispersion. During the simulation period, the uranium plume largely remained within the exclusion and buffer areas of the 200-Area plateau.

Strontium-90 - Transport modeling of the strontium-90 plume in the 200-East Area predicted that the strontium-90 plume will likely migrate very little from its current location within the 200 Area because strontium-90 sorbs strongly to Hanford sediments $\left(K_{d}=20 \mathrm{ml} / \mathrm{g}\right)$. Concentration levels of the simulated plume in the buffer area surrounding the 200 Area will decline over the next 100 years to below regulatory concern by processes of radioactive decay and plume dispersion as the plume migrates from the current location. The strontium-90 plume is predicted to remain largely within the 200 -Area plateau.

In general, the results of transport analyses of tritium, iodine-129, technetium-99, and uranium with the three-dimensional model were in agreement with past site-wide modeling results obtained by Chiaramonte et al. (1996) in support of the Environmental Restoration Program. However, the current three-dimensional model has resulted in higher estimates of peak concentrations at shallow depths and less vertical migration than was predicted in previous site-wide model applications. These discrepancies are attributable to differences in basic assumptions made about the hydrogeologic framework and the horizontal and vertical 
discretization used in each model. The differences in assumptions resulting from each modeling approach affect lateral and vertical distributions of predicted hydraulic heads and contaminants in the unconfined aquifer.

The near-term impacts of existing plumes to on-site drinking water supplies were examined by evaluating predicted concentration levels in the vicinity of identified on-site water supplies over the next 30 years. Projected future levels of tritium suggest that water supply wells in the 400 Area at the Fast Flux Test Facility (FFTF) and emergency water supply wells in the 200-East Area will continue to be impacted by the tritium plume originating from the 200-East Area for the next 10 to 20 years. Tritium levels at well locations in the 400 Area and the 200-East Area are expected to remain above the $20,000-\mathrm{pCi} / \mathrm{L}$ level until sometime between 2010 and 2020. After that time, tritium will continue to decline to below $500 \mathrm{pCi} / \mathrm{L}$ at some time between the years 2070 and 2080. Model results suggest that tritium concentrations now found in the 300 Area in excess of $2,000 \mathrm{pCi} / \mathrm{L}$ will not reach the North Richland well field.

Transport analyses suggest that only water supplies in the 200-East Area could potentially be impacted by elevated levels of iodine-129. Model-predicted levels of iodine-129 suggest that within 20 to 30 years iodine levels in excess of $1 \mathrm{pCi} / \mathrm{L}$ that are currently in the 200-East Area will remain about halfway to the Columbia River. The iodine-129 plumes in the 200-West Area will be expected to migrate slowly toward the 200-East Area but model results (Figure 6.4) suggest that levels in excess of $1 \mathrm{pCi} / \mathrm{L}$ will not reach the 200-East Area within 30 years.

Projected future levels of technetium-99, uranium, and strontium-90 show that none of the identified water supplies on the Hanford Site, including those in the 200-East Area near B Plant and AY/AZ Tank Farm, will be impacted by future transport of these contaminants. 


\section{Acknowledgments}

Several Pacific Northwest National Laboratory staff members contributed to this report. The authors wish to acknowledge Bill Webber for generating the initial contaminant concentrations; JoAnne Rieger for the hydrographs used in transient model comparisons; Dev Felton and Kathy Blanchard for report editing; and Mark Freshley for technical support and guidance, as well as peer review. 



\section{Contents}

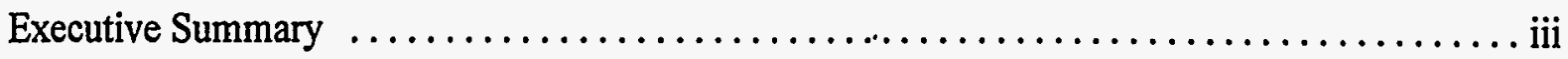

Acknowledgments $\ldots \ldots \ldots \ldots \ldots \ldots \ldots \ldots \ldots \ldots \ldots \ldots \ldots \ldots \ldots \ldots \ldots \ldots \ldots \ldots \ldots$ vii

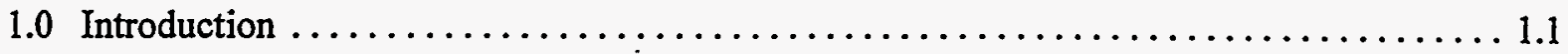

1.1 Purpose and Scope $\ldots \ldots \ldots \ldots \ldots \ldots \ldots \ldots \ldots \ldots \ldots \ldots \ldots \ldots \ldots \ldots \ldots \ldots \ldots \ldots \ldots \ldots \ldots \ldots \ldots .2$

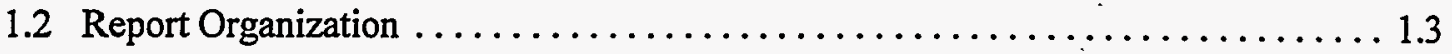

2.0 Other Transport Modeling Efforts at the Hanford Site $\ldots \ldots \ldots \ldots \ldots \ldots \ldots \ldots \ldots \ldots$

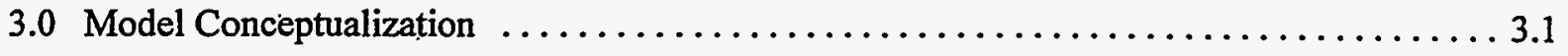

3.1 Hydrogeologic Framework $\ldots \ldots \ldots \ldots \ldots \ldots \ldots \ldots \ldots \ldots \ldots \ldots \ldots \ldots \ldots \ldots \ldots \ldots \ldots \ldots \ldots \ldots$

3.1.1 Recharge and Flow System Boundaries ............... 3.2

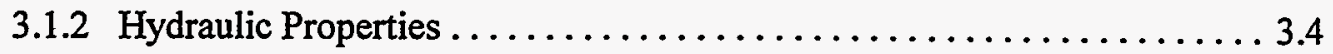

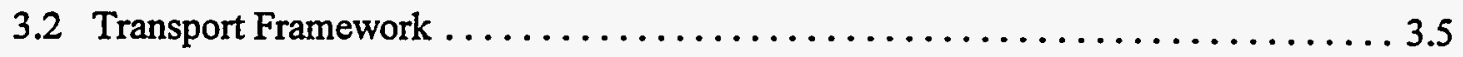

4.0 Three-Dimensional Flow Model $\ldots \ldots \ldots \ldots \ldots \ldots \ldots \ldots \ldots \ldots \ldots \ldots \ldots \ldots \ldots .1$

4.1 Two-Dimensional Flow Model Recalibration $\ldots \ldots \ldots \ldots \ldots \ldots \ldots \ldots \ldots .1$

4.2 Steady-State Three-Dimensional Flow Model Development and Calibration .... 4.3

4.2.1 Hydraulic Properties . . . . . . . . . . . . . . . . . . . . 4.4

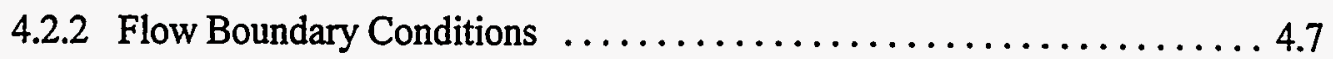

4.3 Three-Dimensional Transient-Flow Model Calibration and Application . . . . . . 4.8

4.3.1 Transient Calibration of 1979 to 1996 Conditions . . . . . . . . . . . 4.9

4.3.2 Simulation of Future Transient Conditions $\ldots \ldots \ldots \ldots \ldots \ldots \ldots . . \ldots$

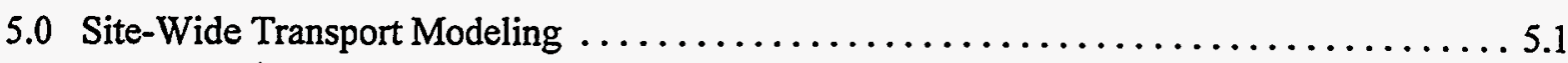

5.1 Transport Finite-Element Grid $\ldots \ldots \ldots \ldots \ldots \ldots \ldots \ldots \ldots \ldots \ldots \ldots \ldots \ldots \ldots \ldots \ldots \ldots \ldots \ldots \ldots \ldots \ldots .1$

5.2 Transport Analysis of the Tritium Plume $\ldots \ldots \ldots \ldots \ldots \ldots \ldots \ldots \ldots \ldots \ldots \ldots \ldots \ldots \ldots \ldots \ldots$

5.2.1 Initial Conditions and Transport Parameters $\ldots \ldots \ldots \ldots \ldots \ldots \ldots . . \ldots$

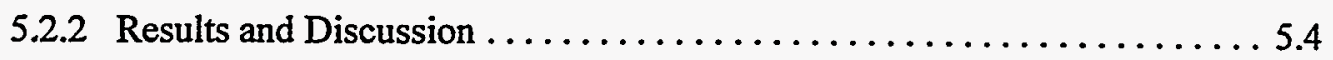


5.3 Transport Analysis of Iodine-129 Plume . . . . . . . . . . . . . 5.7

5.3 .1 Assumptions and Initial Conditions $\ldots \ldots \ldots \ldots \ldots \ldots \ldots \ldots .7$

5.3 .2 Results and Discussion $\ldots \ldots \ldots \ldots \ldots \ldots \ldots \ldots . \ldots \ldots$

5.4 Transport Analysis of Technetium-99 Plume $\ldots \ldots \ldots \ldots \ldots \ldots \ldots \ldots . . \ldots$

5.4 .1 Assumptions and Initial Conditions $\ldots \ldots \ldots \ldots \ldots \ldots \ldots \ldots \ldots \ldots \ldots \ldots \ldots \ldots$

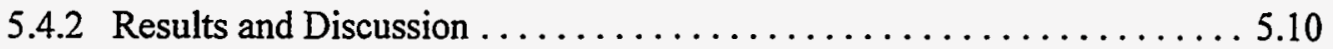

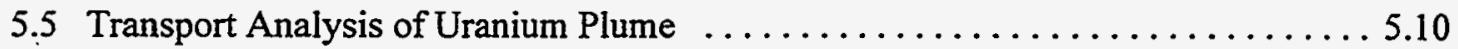

5.5 .1 Assumptions and Initial Conditions $\ldots \ldots \ldots \ldots \ldots \ldots \ldots \ldots .11$

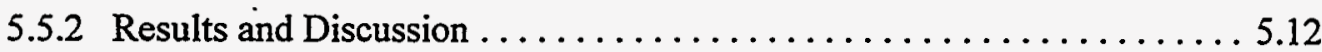

5.6 Transport Analysis of Strontium-90 Plume $\ldots \ldots \ldots \ldots \ldots \ldots \ldots \ldots \ldots \ldots \ldots \ldots \ldots \ldots$

5.6 .1 Assumptions and Initial Conditions . . . . . . . . . . 5.13

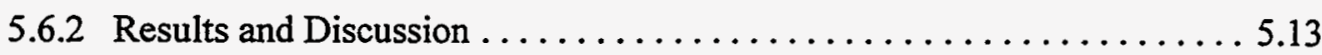

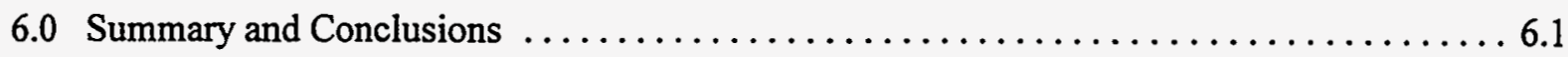

6.1 Current Modeling Results $\ldots \ldots \ldots \ldots \ldots \ldots \ldots \ldots \ldots \ldots \ldots \ldots \ldots \ldots \ldots \ldots \ldots \ldots \ldots \ldots \ldots .1$

6.2 . Comparison of Past Site-Wide Modeling $\ldots \ldots \ldots \ldots \ldots \ldots \ldots \ldots \ldots . . \ldots \ldots \ldots \ldots \ldots$

6.3 Potential Impacts to Site Water Supplies $\ldots \ldots \ldots \ldots \ldots \ldots \ldots \ldots \ldots \ldots \ldots \ldots \ldots \ldots \ldots \ldots$

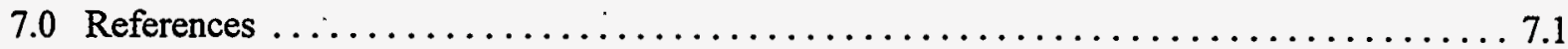

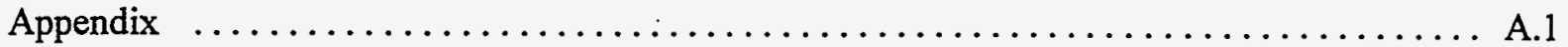




\section{Figures}

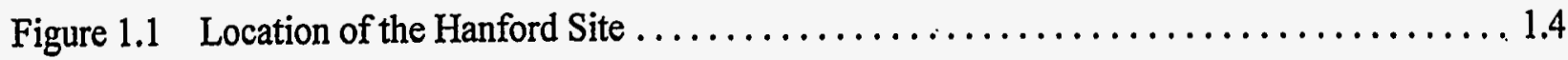

Figure 3.1 Estimated Recharge Rates at Hanford in $1979 \ldots \ldots \ldots \ldots \ldots \ldots \ldots \ldots \ldots \ldots \ldots$

Figure 3.2 Numerical Model Grid and Boundary Conditions $\ldots \ldots \ldots \ldots \ldots \ldots \ldots \ldots .8$

Figure 3.3 Wells and Aquifer Test Results (Transmissivity in $\mathrm{m}^{2} / \mathrm{d}$ ) Used in the Inverse Calibration 3.9

Figure 4.1 Transmissivity Distribution Obtained from Inverse Calibration for 1979 Conditions . . 4.13

Figure 4.2 Comparison of Observed and Predicted Water-Table Conditions for 1979 from the Two-Dimensional Model Using Transmissivities from the Inverse Calibration . . . . . 4.14

Figure 4.3 Hydrogeologic Units Intersecting Water Table for 1979 Conditions . . . . . . . . 4.15

Figure 4.4 Hydraulic Conductivity Distribution in the Uppermost Hydrogeologic Units of the

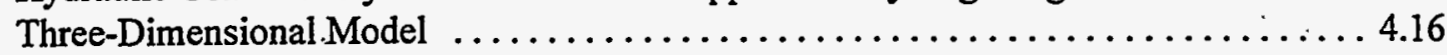

Figure 4.5 Comparison of Observed and Predicted Water-Table Conditions for 1979 Using the Three-Dimensional Model $\ldots \ldots \ldots \ldots \ldots \ldots \ldots \ldots \ldots \ldots \ldots \ldots \ldots \ldots \ldots \ldots \ldots$

Figure 4.6 Difference Between the Observed Water Table and the Water Table Predicted for 1979 with the Three-Dimensional Model $\ldots \ldots \ldots \ldots \ldots \ldots \ldots \ldots \ldots \ldots \ldots \ldots \ldots .18$

Figure 4.7 Comparison of Water-Table Elevations Measured in Wells and Water-Table Elevations Predicted for 1979 with the Three-Dimensional Model .................. 4.19

Figure 4.8 Estimated Annual Effluent Discharges in the 200 Areas Used in the Three-Dimensional Model for Conditions from 1979 to $2026 \ldots \ldots \ldots \ldots \ldots \ldots \ldots \ldots \ldots \ldots \ldots \ldots \ldots \ldots \ldots \ldots \ldots .20$

Figure 4.9 Comparison of 1996 Observed and Predicted Water Table Conditions Using Specific Yield of 0.1 for the Ringold Formation and 0.25 for the Hanford Formation . . . . . . 4.21

Figure 4.10 Hydrographs for Selected Wells and Model Nodes in Areas 1, 2, 3, and 4 from 1979 to 1996

Figure 4.11 Hydrographs for Selected Wells and Model Nodes in Areas 5, 6, 7, and 8 from 1979 to 1996

Figure 4.12 Hydrographs for Selected Wells and Model Nodes in Areas 9, 10, 11, and 12 from 1979 to 1996

Figure 4.13 Hydrographs for Selected Wells and Model Nodes in Areas 13, 14, 15, 16 from 1979 to 1996 
Figure 4.14 Hydrographs for Selected Wells and Model Nodes in Areas 17, 18, 19, and 20 from

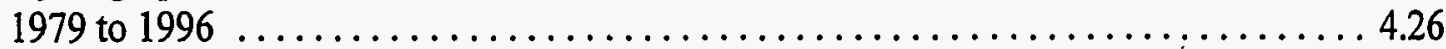

Figure 4.15 Locations of Wells Shown in Hydrographs $\ldots \ldots \ldots \ldots \ldots \ldots \ldots \ldots \ldots .27$

Figure 4.16 Water-Table Conditions for 2000 Predicted with the Three-Dimensional Model .... 4.28

Figure 4.17 Water-Table Conditions for 2100 Predicted with the Three-Dimensional Model . . . . 4.29

Figure 4.18 Water-Table Conditions for 2200 Predicted with the Three-Dimensional Model . . . 4.30

Figure 4.19 Water-Table Conditions for 2350 Predicted with the Three-Dimensional Model . . . . 4.31

Figure 4.20 Hydrographs for Selected Wells and Model Nodes in Areas 1,2,3, and 4 from

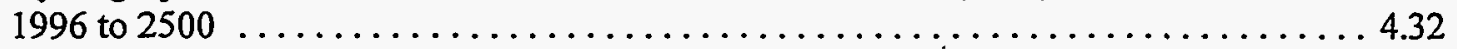

Figure 4.21 Hydrographs for Selected Wells and Model Nodes in Areas 5, 6, 7, and 8 from 1996 to 2500 ......................................... 4.33

Figure 4.22 Hydrographs for Selected Wells and Model Nodes in Areas 9, 10, 11, and 12 from

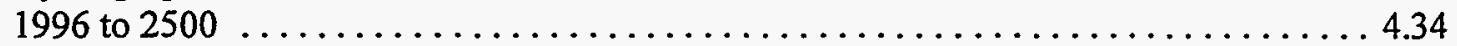

Figure 4.23 Hydrographs for Selected Wells and Model Nodes in Areas 13, 14, 15, and 16 from

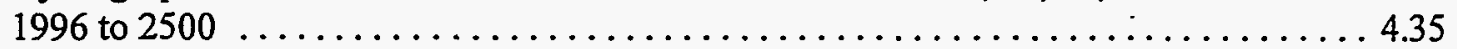

Figure 4.24 Hydrographs for Selected Wells and Model Nodes in Areas 17, 18, 19, and 20 from

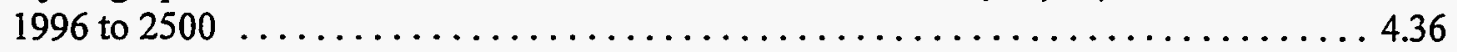

Figure 4.25 Difference Between Hanford Water-Table Conditions Predicted for 2350 and $1996 \ldots 4.37$

Figure 4.26 Comparison of Hanford Water-Table Conditions Predicted for 2350 and Estimated

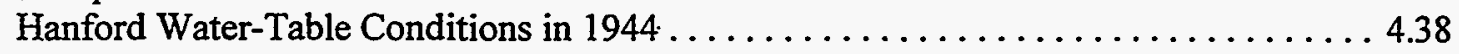

Figure 5.1 Refined Finite-Element Grid Used for Three-Dimensional Transport Simulations . . . . 5.15

Figure 5.2 Areal Distribution of Tritium Used as Initial Conditions for Transport Modeling . . . 5.16

Figure 5.3 Areal Distribution of Tritium in 1985 as Predicted with the Three-Dimensional

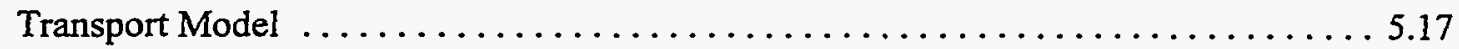

Figure 5.4 Areal Distribution of Tritium in 1996 as Predicted with the Three-Dimensional Transport Model $\ldots \ldots \ldots \ldots \ldots \ldots \ldots \ldots \ldots \ldots \ldots \ldots \ldots \ldots \ldots \ldots \ldots \ldots \ldots .18$

Figure 5.5 Observed Tritium for 1996 Conditions $\ldots \ldots \ldots \ldots \ldots \ldots \ldots \ldots \ldots \ldots \ldots \ldots \ldots \ldots \ldots \ldots \ldots \ldots$

Figure 5.6 Areal Distribution of Tritium in 2000 as Predicted with the Three-Dimensional Transport Model 
Figure 5.7 Areal Distribution of Tritium in 2020 as Predicted with the Three-Dimensional

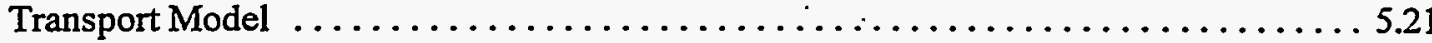

Figure 5.8 Areal Distribution of Tritium in 2050 as Predicted with the Three-Dimensional

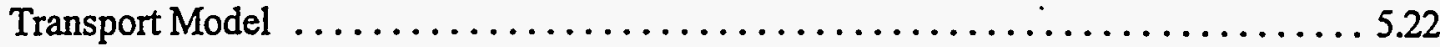

Figure 5.9 Areal Distribution of Tritium in 2100 as Predicted with the Three-Dimensional

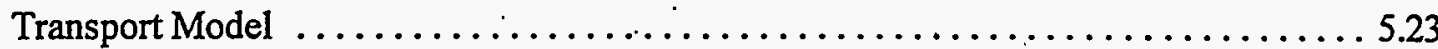

Figure 5.10 Areal Distribution of Iodine-129 Used as Initial Conditions for Transport Modeling . . 5.24

Figure 5.11 Areal Distribution of Iodine-129 in 2031 as Predicted with the Three-Dimensional

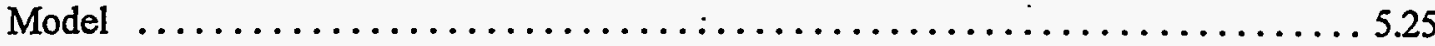

Figure 5.12 Areal Distribution of Iodine-129 in 2049 as Predicted with the Three-Dimensional

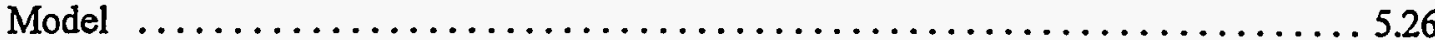

Figure 5.13 Areal Distribution of Iodine-129 in 2099 as Predicted with the Three-Dimensional

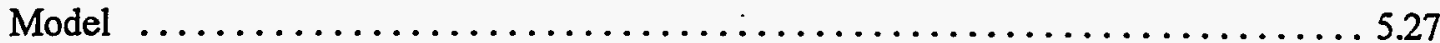

Figure 5.14 Areal Distribution of Iodine-129 in 2299 as Predicted with the Three-Dimensional

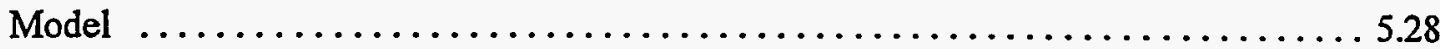

Figure 5.15 Areal Distribution of Technetium-99 Used as Initial Conditions for Transport Modeling

Figure 5.16 Areal Distribution of Technetium-99 in 2000 as Predicted with the Three-Dimensional

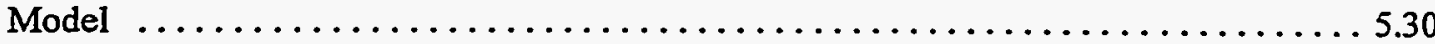

Figure 5.17 Areal Distribution of Technetium-99 in 2031 as Predicted with the Three-Dimensional

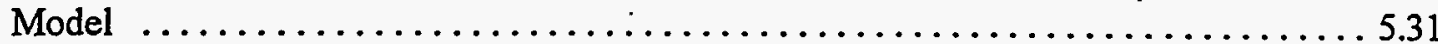

Figure 5.18 Areal Distribution of Technetium-99 in 2049 as Predicted with the Three-Dimensional

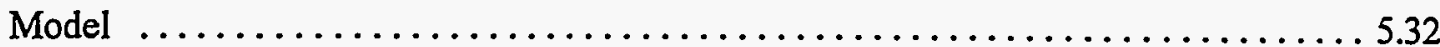

Figure 5.19 Areal Distribution of Technetium-99 in 2099 as Predicted with the Three-Dimensional

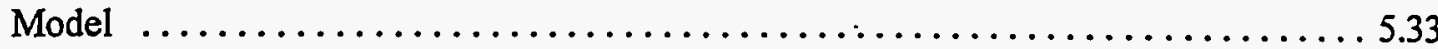

Figure 5.20 Areal Distribution of Uranium Used as Initial Conditions for Transport Modeling . . . 5.34

Figure 5.21 Areal Distribution of Uranium in 2031 as Predicted with the Three-Dimensional

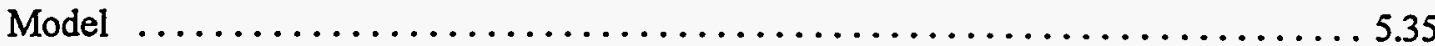

Figure 5.22 Areal Distribution of Uranium in 2049 as Predicted with the Three-Dimensional

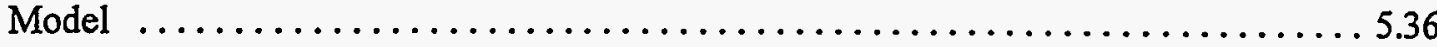

Figure 5.23 Areal Distribution of Uranium in 2099 as Predicted with the Three-Dimensional

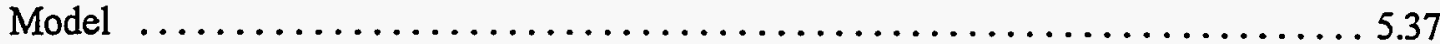


Figure 5.24 Areal Distribution of Uranium in 2299 as Predicted with the Three-Dimensional

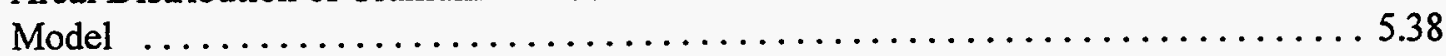

Figure 5.25 Areal Distribution of Strontium-90 Used as Initial Conditions for Transport Modeling

Figure 5.26 Areal Distribution of Strontium-90 in 2031 as Predicted with the Three-Dimensional

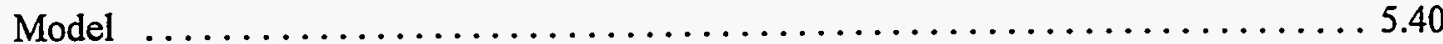

Figure 5.27 Areal Distribution of Strontium-90 in 2049 as Predicted with the Three-Dimensional

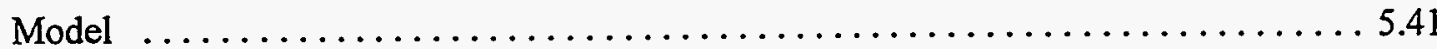

Figure 5.28 Areal Distribution of Strontium-90 in 2099 as Predicted with the Three-Dimensional

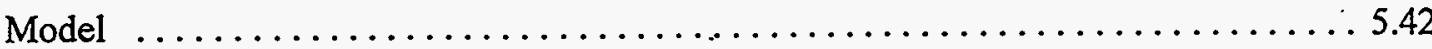

Figure 5.29 Areal Distribution of Strontium-90 in 2299 as Predicted with the Three-Dimensional

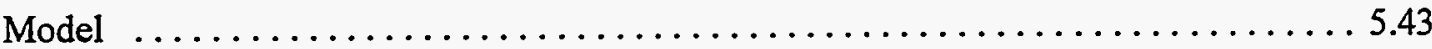

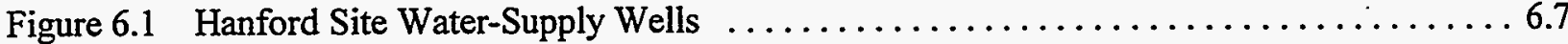

Figure 6.2 Northwest-to-Southeast Cross Section Through the 400 Area Showing Major Hydrogeologic Units, the Location of Drinking-Water Supply Wells, and Predicted Levels of Tritium for Conditions 1996 and 2000

Figure 6.3 Northwest-to-Southeast Cross Section Through the 400 Area Showing Major Hydrogeologic Units, the Location of Drinking-Water Supply Wells, and Predicted

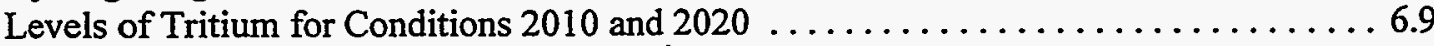

Figure 6.4 Simulated Position of $20,000 \mathrm{pCi} / \mathrm{L}$ Tritium Contour for 1996,2020 , and $2030 \ldots \ldots 6.10$

Figure 6.5 Simulated Position of $1 \mathrm{pCi} / \mathrm{L}$ Iodine-129 Contour for 1996 and $2031 \ldots \ldots \ldots \ldots .11$ 


\section{Tables}

3.1 Major Hydrogeologic Units Used in the Site-Wide Three-Dimensional Model . . . . . . . . . 3.2

3.2 Best Estimate Distribution Coefficents Used in Simulations of Iodine-129, Technetium-99,

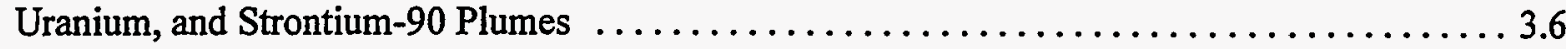

3.3 Transport Properties Used in Simulations of Existing Plumes $\ldots \ldots \ldots \ldots \ldots \ldots \ldots \ldots .7$

4.1 Assumed Hydraulic Conductivities for Major Hydrogeologic Units Used in the Redistribution of Inverse Calibrated Transmissivities to the Three- Dimensional Model $\ldots \ldots \ldots \ldots \ldots \ldots .5$

4.2 Statistical Comparison of Differences Between Observed and Predicted 1979 Water-Table Elevations Evaluated Model Nodes . . . . . . . . . . . . . . . . . . . . . . 4.8 


\subsection{Introduction}

Monitoring of groundwater across the Hanford Site (Figure 1.1) has characterized a number of radioactive contaminant plumes that emanate from various operational areas (Hartman and Dresel 1997). The most widespread plumes are from groundwater contaminated by tritium and iodine-129. Smaller plumes of strontium-90, technetium-99, and plutonium contain concentrations exceeding U.S. Environmental Protection Agency (EPA) and State of Washington interim drinking-water standards (DWS). Uranium concentrations are also found at levels greater than those in the proposed DWS. In recent years, concentrations of cesium- 137 and cobalt- 60 have also been found at a few locations at levels that equal or exceed the DWS.

The Hanford Groundwater Project (HGWP), managed by Pacific Northwest National Laboratory, is responsible for monitoring and assessing the movement of contaminants in groundwater at the Hanford Site. As part of this responsibility, the HGWP has supported the development of groundwater models to assist in identifying and quantifying existing, emerging, or potential groundwater quality problems and in assessing the potential for contaminants to migrate from the Hanford Site to the accessible environment through the groundwater pathway. A three-dimensional numerical model of groundwater flow and contaminant transport has been developed for the unconfined aquifer system. Numerical models of the groundwater flow system were previously developed and served as important tools for estimating future conditions and predicting the movement of contaminants in the unconfined aquifer. The HGWP supported the development and maintenance of a two-dimensional model (Wurstner and Devary 1993) and, more recently, a three-dimensional model (Wurstner et al. 1995).

This report describes improvements to the three-dimensional model during fiscal year (FY) 1996 and 1997 and the model's application in modeling flow and transport of selected contaminant plumes in the unconfined aquifer. The applications presented in this report consist of predicted changes in transient-flow conditions in the unconfined aquifer to the year 4000 . These predicted transient-flow conditions provided the hydrologic basis for simulating migration of selected contaminants. Forecasted contaminant migration includes the transport of the tritium plume resulting from future operations of the State-Approved Land Disposal Site (SALDS) and the transport of the existing tritium, iodine-129, technetium-99, uranium, and strontium-90 plumes originating from the 200 Areas for the Hanford Site Composite Analysis. 


\subsection{Purpose and Scope}

Two-dimensional models have been used extensively at the Hanford Site and are generally adequate for predicting aquifer head changes and groundwater flow paths and travel times. The three-dimensional model described in this report was developed 1) to assist the HGWP in interpreting monitoring data; 2) to investigate contaminant mass transport issues and evaluate the future movement of contaminant plumes; and 3) to identify and quantify potential groundwater quality problems for on-site and off-site use.

The scope of activities associated with developing and applying the three-dimensional model in FY 1996 and 1997 was to

- recalibrate a two-dimensional model with an inverse calibration method

- refine the three-dimensional conceptual model of the Site

- develop and calibrate a numerical model based on the three-dimensional conceptualization that preserves the two-dimensional calibration results

- apply the three-dimensional model to simulate future transport of existing plumes, and

- determine impacts to on-site drinking water supplies.

The inverse calibration procedure described in Wurstner et al. (1995) resulted in hydraulic conductivities near Gable Mountain Pond that were too high because the inverse calibration was not properly constrained with respect to observed transmissivities. Part of the effort during FY 1996 and 1997 was to recalibrate the site-wide flow model while constraining the inverse model with observed transmissivity data.

The two- and three-dimensional models were developed using the Coupled Fluid, Energy, and Solute Transport (CFEST) code (Gupta et al. 1987). Wurstner et al. (1995) describes the capabilities and approach used in the CFEST code and the code's selection for the project. The supercomputer version (CFEST-SC), developed to run on all major Unix work stations (Cole et al. 1988), was used for all flow and transport modeling prior to FY 1997. In FY1997, the refinement of this three-dimensional flow model 
and its application to contaminant transport in selected contaminant plumes continued with an updated version of the CFEST code called CFEST96 (Gupta1997).

Output from CFEST was graphically displayed using the $\mathrm{Arc} / \mathrm{Info}{ }^{\otimes}{ }^{(b)}$ geographic information system (GIS). The Arc/Info ${ }^{\circledR}$ GIS package was also used to store fundamental hydrogeologic data and information used to represent the three-dimensional conceptual model. The Geological Finite-Element Synthesis Tool (GEOFEST) described in Foley et al. (1995) was used to construct the three-dimensional numerical model from the GIS layers.

\subsection{Report Organization}

This report is organized as follows. Section 2.0 briefly describes other site-wide modeling efforts that have been conducted on the Hanford Site and that are relevant to the current model development. Section 3.0 describes the hydrogeologic and transport framework used in the modeling. Section 4.0 describes the calibration and application of the three-dimensional flow model. Section 5.0 describes the application of the three-dimensional transport model in predicting future transport of the tritium, technetium, uranium, iodine-129, and strontium-90 plumes originating from the 200 Areas. Section 6.0 discusses the results obtained from this modeling effort. Appendix A provides a table of artificial recharge volumes and spring discharges used as input for the three-dimensional model. The second table in Appendix A provides input concentrations for simulating tritium plume transport.

(b) Arc/Info® is a registered trademark of Environmental Systems Research Institute, Inc., Redlands, California . 


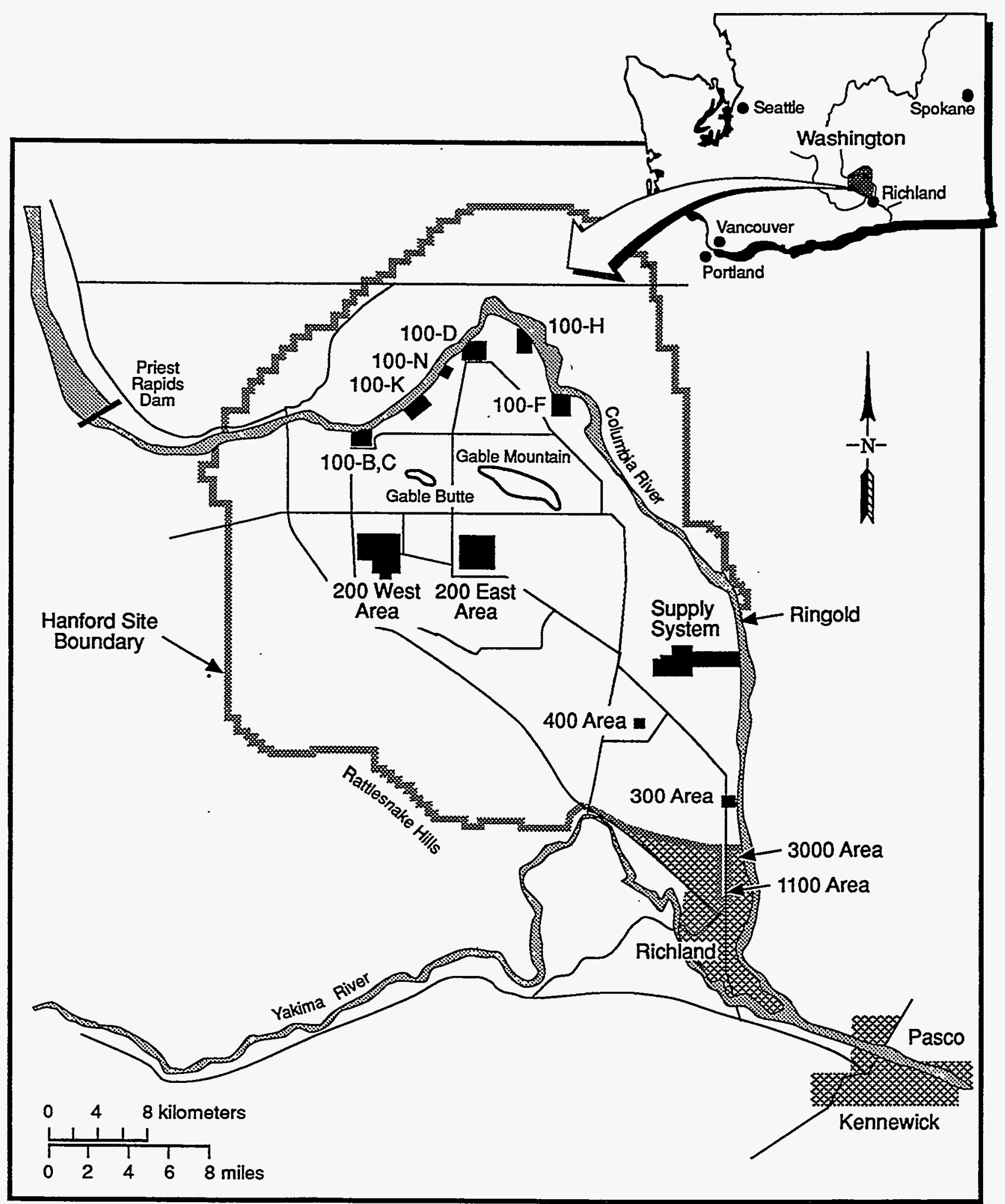

S9311035.1

Figure 1.1. Location of the Hanford Site 


\subsection{Other Transport Modeling Efforts at the Hanford Site}

Wurstner et al. (1995) summarize previous groundwater flow and contaminant transport model development and applications at the Hanford Site. Recently, a two-layer model of the unconfined aquifer, based on the VAM-3D code, was developed and applied (Law et al. 1996). This model was applied to simulate migration of tritium, nitrate, iodine-129, trichloroethylene, chloroform, uranium, and carbon tetrachloride plumes in the aquifer to provide input for developing the Hanford Site-wide Groundwater Remediation Strategy (Chiaramonte et al. 1996). These flow and transport simulations were conducted for a time period of 200 years and predicted that the groundwater flow system required 100 to 125 years to reach a steady-state condition. At steady state, the flow direction is predominantly from west to east. As the heads decrease and the water table is predicted to be within the Ringold Formation, the groundwater flow velocities were predicted to decline significantly, slowing the rate of migration of the various contaminant plumes. The Chiaramonte et al. (1996) model predicted that tritium discharged to the SALDS will not migrate beyond the Central Plateau, which is the area that encompasses the 200-West and 200-East Areas. The tritium plume to the east of the 200 Area is predicted to continue migrating toward the Columbia River and to reduce in size because of radioactive decay.

Other flow and transport models of the unconfined aquifer have been developed and applied. Connelly et al. (1992a, b) developed models of the 200-East and 200-West Areas to support Resource Conservation and Recovery Act (RCRA) and Comprehensive Environmental Response, Compensation, and Liability Act (CERCLA) investigations.

Golder Associates, Inc. constructed a site-wide model that was applied to support the Washington State Discharge WAC 173-216 permit application for the SALDS. This model was applied with the assumption that the source concentrations remained constant over the entire simulation period (205 years), rather than 20 years as assumed for the current model. This assumption resulted in prediction of a large tritium plume extending north of Gable Butte.

Future efforts in groundwater modeling will be focused on integrating the multiple databases and models into a single set of conceptual and numerical models for the Hanford Site, to ensure consistency in how data are interpreted and how models are applied at Hanford. 


\subsection{Model Conceptualization}

This section briefly describes the conceptual model of the Hanford Site unconfined aquifer system. The conceptual model was developed from information on the hydrogeologic structure of the aquifer, spatial distributions of hydraulic and transport properties, aquifer boundary conditions, and distribution and movement of contaminants. Development of the three-dimensional conceptual model is documented in Thorne and Chamness (1992), Thorne et al. (1993, 1994), and Wurstner et al. (1995).

\subsection{Hydrogeologic Framework}

The Hanford Site lies within the Pasco Basin, a structural depression that has accumulated a relatively thick sequence of fluvial, lacustrine, and glacio-fluvial sediments. The geology and hydrology of the Hanford Site have been studied extensively for more than 50 years and are summarized in documents referenced in Wurstner et al. (1995). The Pasco Basin and nearby anticlines and synclines initially developed in the underlying Columbia River Basalt Group, a sequence of continental flood basalts covering more than $160,000 \mathrm{~km}^{2}$. Overlying the basalt within the Pasco Basin are fluvial and lacustrine sediments of the Ringold Formation and the glacio-fluvial Hanford Formation. Together, these sedimentary deposits comprise the Hanford Site unconfined aquifer system. The saturated thickness of this unconfined aquifer system is greater than $61 \mathrm{~m}$ in some areas but pinches out along the flanks of the basalt ridges. Depth to the groundwater ranges from less than $0.3 \mathrm{~m}$ near the Columbia-River to more than $100 \mathrm{~m}$ in the 200-Area plateau. Groundwater in this unconfined aquifer system generally flows from recharge areas to the south and west of the Hanford Site to the Columbia River in the east.

The lateral extent and relationships between the hydrogeologic units of the Ringold and Hanford formations were defined by identifying distinct hydrogeologic units to adequately represent the unconfined aquifer, and by determining geologic contacts between these layers at as many wells as possible. These interpreted areal distributions and thicknesses were integrated into EarthVision, ${ }^{\otimes(c)} a$ three-dimensional visualization software package that was then used to construct a database for formulation in the three-dimensional Site conceptual model. The resulting conceptual model contains nine hydrogeologic units above the uppermost basalt. A brief summary of each of these units, based on descriptions provided in Wurstner et al. (1995), is provided in Table 3.1.

(c) Earth Vision ${ }^{\otimes}$ is a registered trademark of Dynamic Graphics, Inc., Alameda, California 
Table 3.1. Major Hydrogeologic Units Used in the Site-Wide Three-Dimensional Model

\begin{tabular}{|c|l|l||}
\hline $\begin{array}{c}\text { Unit } \\
\text { Number }\end{array}$ & Hydrogeologic Unit & Lithologic Description \\
\hline 1 & $\begin{array}{l}\text { Hanford Formation/ } \\
\text { Pre-Missoula Gravels }\end{array}$ & Fluvial gravels and coarse sands \\
\hline 2 & Palouse Soil & Fine-grained sediments and eolian silts \\
\hline 3 & Plio-Pleistocene Unit & Buried soil horizon containing caliche and basaltic gravels \\
\hline 4 & Upper Ringold Mud & Fine-grained fluvial/lacustrine sediments \\
\hline 5 & Middle Ringold & Semi-indurated coarse-grained fluvial sediments \\
\hline 6 & Middle Ringold & $\begin{array}{l}\text { Fine-grained sediments with some interbedded coarse- } \\
\text { grained sediments }\end{array}$ \\
\hline 7 & Middle Ringold & Coarse-grained sediments \\
\hline 8 & $\begin{array}{l}\text { Lower Mud Sequence } \\
\text { Ringold }\end{array}$ & Lower blue or green clay or mud sequence \\
\hline 9 & Basal Ringold & Fluvial sand and gravel \\
\hline 10 & Columbia River Basalt & Basalt \\
\hline
\end{tabular}

\subsubsection{Recharge and Flow System Boundaries}

Natural recharge to the unconfined aquifer system occurs from infiltration of 1) runoff from elevated regions along the western boundary of the site, 2) spring discharges originating from the confined basalt aquifer system, and 3) precipitation falling across the Hanford Site. Some recharge also occurs along the Yakima River in the southern portion of the Site. Natural recharge from runoff and irrigation in Cold Creek Valley (upgradient of the Site) provides a source of groundwater inflow to the area of interest. Areal recharge from precipitation falling on the Hanford Site is highly variable, both spatially and temporally, and depends on local climate, soil type, and vegetation. Estimates of recharge based on site-wide variation in these parameters, developed by Fayer and Walters (1995) for 1979 conditions (Figure 3.1), illustrate this range in variability.

The other source of recharge to the unconfined aquifer is artificial recharge from waste water disposal. The large volume of waste water discharged to disposal facilities at the Hanford Site over the past 50 years has significantly impacted groundwater flow and contaminant transport in the unconfined aquifer. The 
volume of artificial recharge has decreased significantly during the past 10 years and continues to decrease. The major discharge facilities considered in this analysis are summarized in Wurstner et al. (1995).

Boundary conditions shown in Figure 3.2 illustrate that the Hanford Site unconfined aquifer system is bounded by the Columbia River on the north and east and by basalt ridges on the south and west. The Columbia River represents a point of regional discharge for the unconfined aquifer. The amount of groundwater discharging to the river is a function of the local hydraulic properties of the aquifer and of the hydraulic gradient between the groundwater elevation alongside or beneath the river, and the river stage. This hydraulic gradient is variable at any given time, since the river stage is affected by seasonal variations in precipitation and temperatures in other regions of the river drainage system. The river stage is also impacted by weekly and daily changes in river flows at numerous dams on the river, as determined by electric power generation needs, fisheries resources management, and other dam operations. In previous three-dimensional modeling efforts, the entire boundary at the edge of the Columbia River was represented as a constant head over the entire thickness of the unconfined aquifer. The CHARIMA river model (Walters et al. 1994) was used to generate long-term average water surface elevations for the Columbia River based on 1979 conditions. In the current model the Columbia River boundary was extended from the left edge of the river to the middle of the river channel to more accurately reflect the hydraulic interaction of the unconfined aquifer and the river. The surface nodes at the river edge and center were simulated as constant-head boundary conditions reflective of the assumed river stage. The nodes below the surface and along the center of the river were simulated as no-flow boundaries. This design leads to a more accurate approximation of the upward movement of groundwater as the groundwater flow is controlled by the hydraulic gradient between the aquifer and the river.

An areal depiction of the surface finite-element grid and boundary conditions used in the threedimensional models of the unconfined aquifer is illustrated in Figure 3.2. The finite-element grid is a more regularly spaced grid than has been described in previous reports and used in previous applications. The grid was redesigned to increase the overall effectiveness and efficiency of the three-dimensional model to simulate both flow and transport problems. Most of the interior surface grid spaces are rectangular and are about $750 \mathrm{~m}$ on a side. The total number of surface elements used in both the two-dimensional and threedimensional model is 1606 elements. The three-dimensional model based on this surface grid is made up of a total of 7200 elements (1606 surface and 5594 subsurface elements) and 8465 nodes. 
At the Cold Creek and Dry Creek valleys (see Figure 3.2), the unconfined aquifer extends westward beyond the boundary of the Hanford Site groundwater flow model. To approximate the groundwater flux entering the modeled area from these valleys, both constant head and constant flux boundary conditions were defined across these valleys. A constant head boundary condition was specified for Cold Creek Valley for the steady-state model calibration runs. Once calibrated, the steady-state model was used to calculate the flux condition that was then used in the transient simulations. The constant flux boundary was used because it better represents the response of the boundary to a declining water table than does a constant head boundary. Previous versions of the three-dimensional model did not include boundary fluxes where Dry Creek enters the modeled area. In the current model, boundary fluxes are prescribed at the north and east valleys of Dry Creek along the southwestern edge of the model boundary. The addition of these boundary fluxes is consistent with observations of water levels in nearby wells in this area. The unconfined aquifer is also recharged from springs and runoff that infiltrate the aquifer along the northern side of Rattlesnake Hills.

Since the last description of the site-wide model provided in Wurstner et al. (1995), changes have been made to the areal extent of the model, model boundary conditions, and model grid design to reflect the most recent understanding and interpretation of the unconfined aquifer system. The most significant changes incorporated in the current version of the site-wide models were derived from reinterpretation of the 1979 water-table surface of the unconfined aquifer and the top of the basalt, which led to changes in both internal and lateral boundary conditions, including:

- inward movement of the model boundary along Rattlesnake Ridge and the Yakima River to more closely approximate the location where basalt intersects the water-table surface, and

- changes in the areal extent of the basalt subcrops above the water-table surface in areas south and east of Gable Mountain and northwest of Gable Butte, to more closely approximate the location where basalt intersects the water-table surface.

\subsubsection{Hydraulic Properties}

Hydraulic properties important to the conceptual model include both horizontal and vertical hydraulic conductivities, storativity, and specific yield. To apply a numerical model, the distribution of these parameters must be specified for each hydrogeologic unit. Hydraulic properties have been measured for 
unconfined aquifer (considered as a simple hydrogeologic unit) mainly during aquifer pumping tests and from laboratory permeability tests. The results of these tests have been documented in published and unpublished reports over the past 50 years and in more recent summaries (U.S. DOE 1988; Thorne and Newcomer 1992). As indicated in these documents, the quality of results from aquifer tests at the Site varies widely and is affected by both aquifer conditions and analysis procedures. Thorne and Newcomer (1992) and Wurstner et al. (1995) reanalyzed the aquifer tests, many of which were single-well pumping tests, and they selected the set of aquifer transmissivity calibration data (Figure 3.3) used in the twodimensional inverse model.

\subsection{Transport Framework}

Estimates of model parameters were developed to account for contaminant disperison and adsorption in all transport simulations. Specific model parameters examined included longitudinal and transverse dispersivity $\left(D_{1}\right.$ and $\left.D_{t}\right)$ and contaminant retardation factors $\left(R_{f}\right)$. Calculation of effective $R_{f}$ required estimates of contaminant-specific distribution coefficients as well as estimates of effective bulk density and porosity of the aquifer materials. This section briefly summarizes estimated transport properties.

For this analysis, a longitudinal dispersivity of $90 \mathrm{~m}$ was selected to be within the range of recommended grid Peclet numbers $\left(\mathrm{P}_{e}<4\right)$ for acceptable solutions. The $90 \mathrm{~m}$ estimate is about onequarter of the grid spacing in the finest part of the model grid in the 200-Area plateau where the smallest grid spacing is on the order of about $375 \mathrm{~m}$ by $375 \mathrm{~m}$. The effective transverse dispersivity was assumed to be one-tenth of the longitudinal dispersivity. Therefore, $9 \mathrm{~m}$ was used in all simulations.

For purposes of this analysis, no adsorption was accounted for in simulating the tritium plumes. However, for the iodine-129, technetium-99, uranium, and strontium-90 plumes simulated in this analysis, best-estimate distribution coefficients $\left(\mathrm{K}_{\mathrm{d}}\right)$ were developed from work summarized in several sources including Rhodes (1956); Nelson (1959); Routson et al. (1978); Serne et al. (1993); Kaplan and Serne (1995), and Kaplan et al. (1996). Table 3.2 provides a summary of these best estimate values, the range of estimates, and the associated reference.

In addition to the estimated distribution coefficient, calculation of contaminant-specific retardation factors used in the model requires estimates of the effective bulk density and porosity. For purposes of these calculations, a bulk density of $1.9 \mathrm{~g} / \mathrm{cm}^{3}$ was used for all simulations. The effective porosity was 
estimated from specific yields obtained from multiple-well aquifer tests. These values range from 0.01 to 0.37. Laboratory measurements of porosity, which range from 0.19 to 0.41 , were available for samples from a few Hanford Site wells and were also considered. The few tracer tests conducted indicate effective porosities ranging from 0.1 to 0.25 . Based on the ranges of values considered, a best estimate of an effective porosity value for all simulations was assumed to be 0.25 .

Table 3.2. Best Estimate Distribution Coefficents Used in Simulations of Iodine-129, Technetium-99, Uranium, and Strontium-90 Plumes

\begin{tabular}{|c|c|c|c|}
\hline \multirow[b]{2}{*}{$\begin{array}{c}\text { Plume } \\
\text { Constituent }\end{array}$} & \multicolumn{2}{|c|}{$\begin{array}{l}\text { Distribution Coefficient }\left(K_{d}\right) \\
(\mathrm{ml} / \mathrm{g})\end{array}$} & \multirow[b]{2}{*}{ Reference } \\
\hline & $\begin{array}{l}\text { Best Estimate } \\
\text { Value }\end{array}$ & $\begin{array}{l}\text { Range of } \\
\text { Estimates }\end{array}$ & \\
\hline Iodine- 129 & 0.5 & 0.2 to 15 & Kaplan and Serne (1995), Kaplan et al. (1996) \\
\hline Technetium-99 & 0 & -2.8 to 0.6 & Kaplan and Serne (1995) \\
\hline Uranium & 3 & 0.1 to 79 & Kaplan and Serne (1995) \\
\hline Strontium-90 & 20 & 5 to 173 & $\begin{array}{l}\text { Routson et al. (1978); Serne et al. (1993); } \\
\text { Rhodes (1956); and Nelson (1959) }\end{array}$ \\
\hline
\end{tabular}




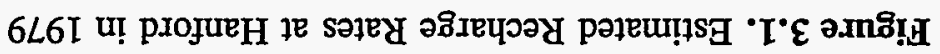

L661 '0Z دaqopo sch"910mysL6

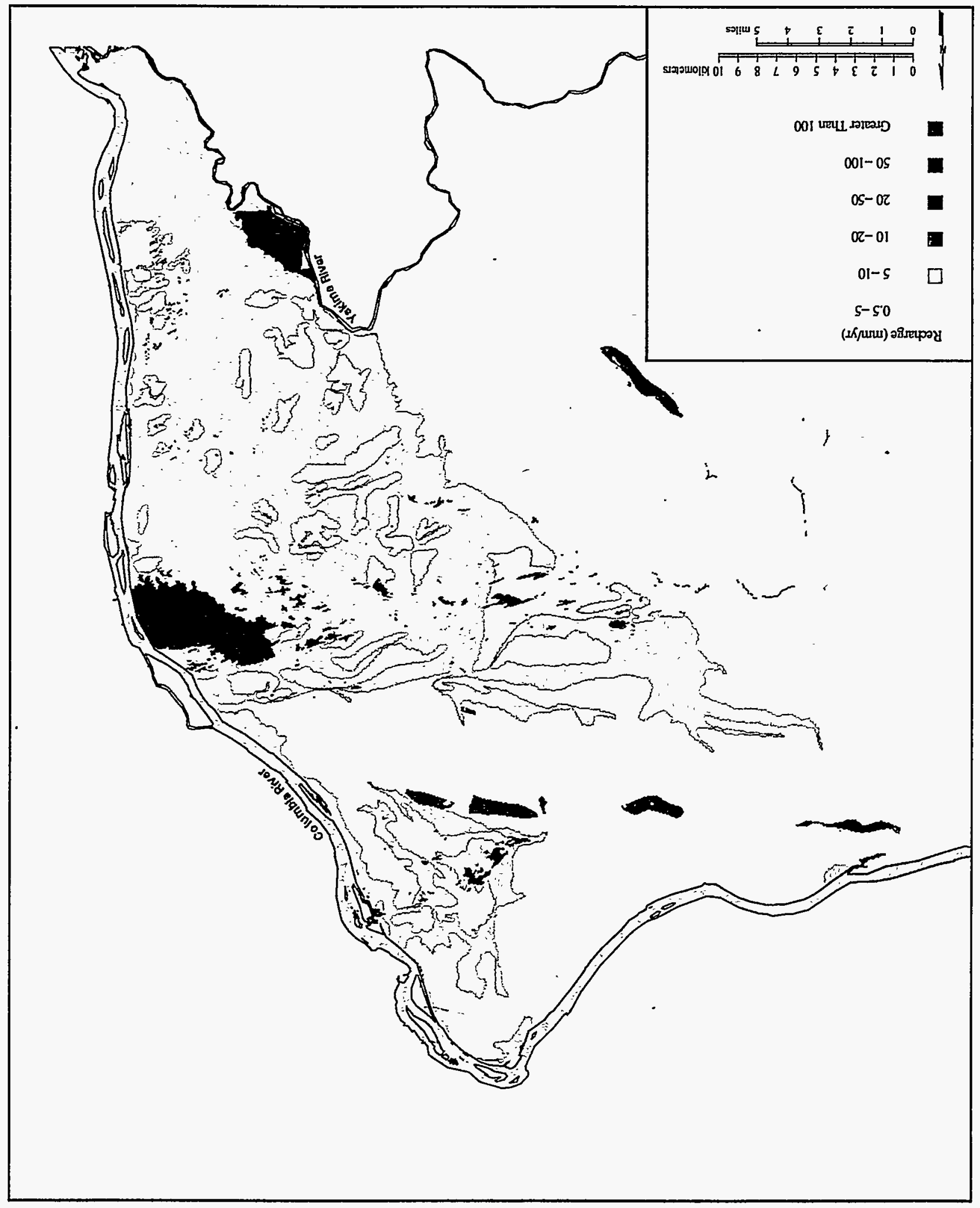




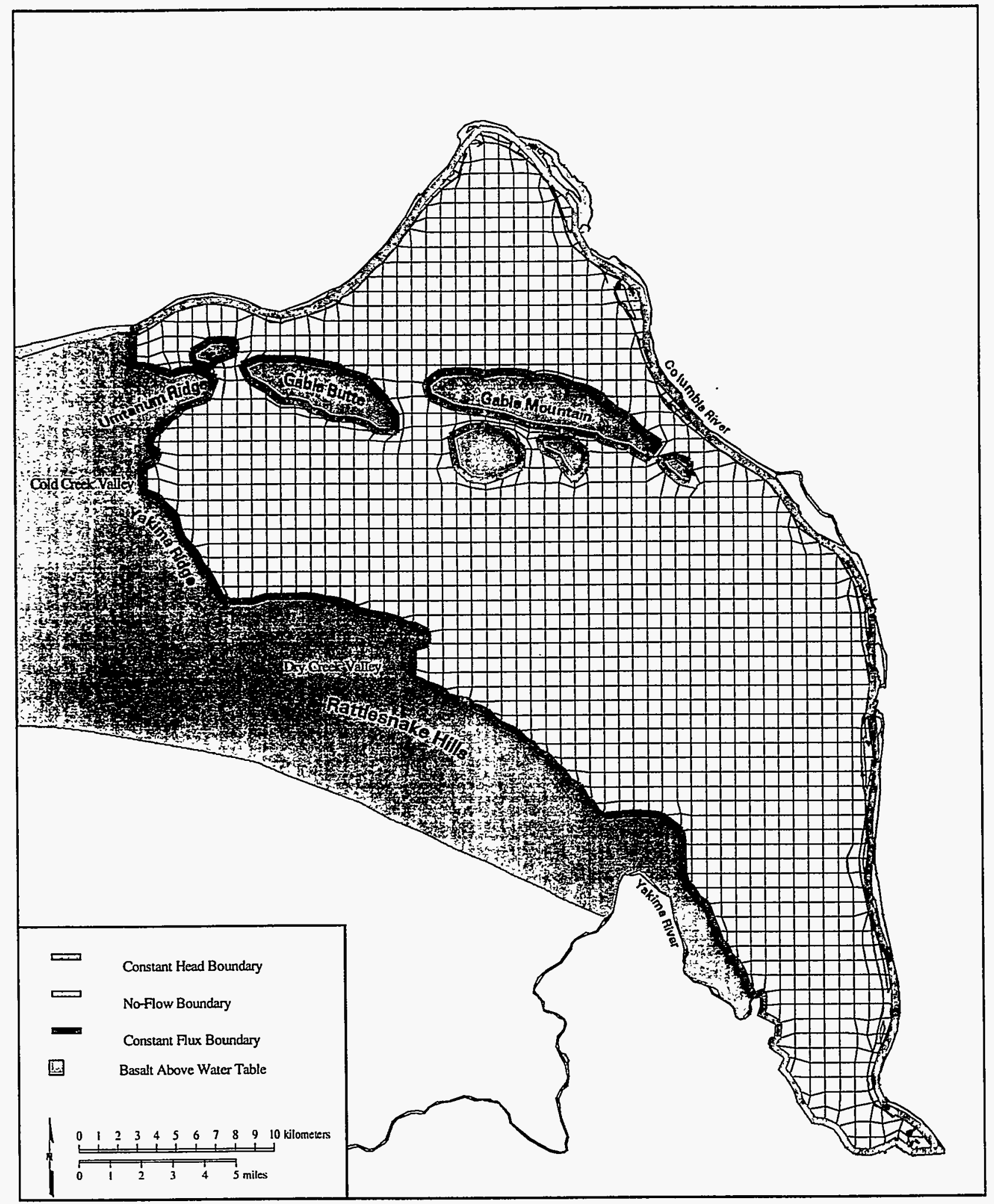

97skw017.eps November 26, 1997

Figure 3.2. Numerical Model Grid and Boundary Conditions 


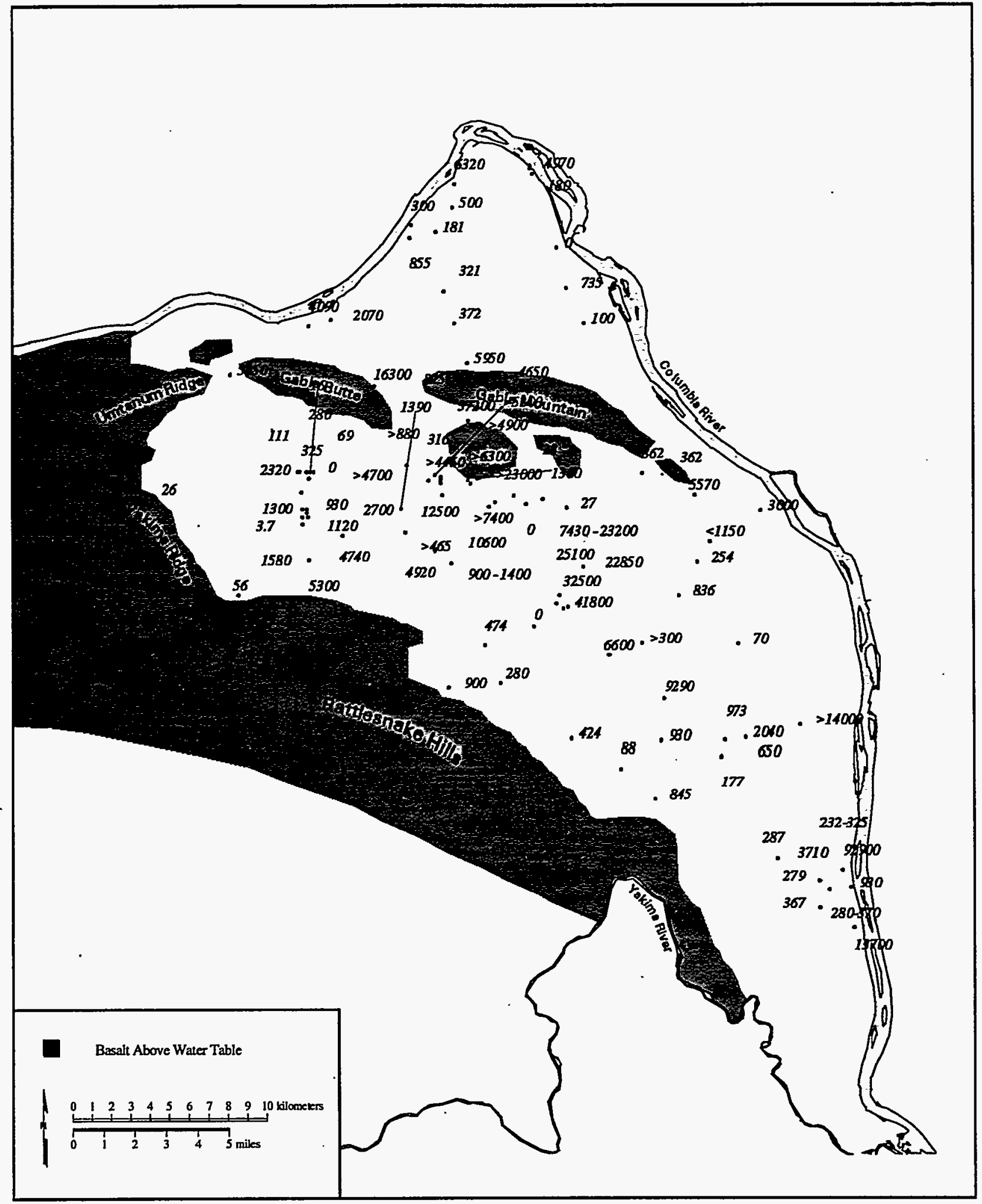

97skw018.eps November 26, 1997

Figure 3.3. Wells and Aquifer Test Results (Transmissivity in $\mathrm{m}^{2} / \mathrm{d}$ ) Used in the Inverse Calibration 


\subsection{Three-Dimensional Flow Model}

The three-dimensional flow model was developed and calibrated to be consistent with hydraulic property distributions (i.e., transmissivities) and boundary conditions used in calibrating the twodimensional inverse model. The overall transmissivity of the aquifer, determined by inverse modeling with the two-dimensional model, was used with available data on hydraulic properties of each of the sub-watertable layers of the model to redistribute the calibrated transmissivity over the model layers used in the three-dimensional model. This aspect of the development of the three-dimensional model is described in Wurstner et al. (1995).

In this section, the development of the three-dimensional flow model is described, including:

- a reevaluation of transmissivity distributions developed in the previous inverse calibration of the two-dimensional model by Wurstner et al. (1995). This reevaluation led to a refinement of the transmissivity distribution derived from the previous inverse calibration of the model in certain areas,

- the development and calibration of a three-dimensional flow model to 1979 flow conditions,

- the calibration of a transient three-dimensional flow model to flow conditions between 1979 and 1996 , and

- the application of the three-dimensional model to predict future transient-flow conditions from 1996 as a result of anticipated conditions following Hanford Site closure.

\subsection{Two-Dimensional Flow Model Recalibration}

The two-dimensional groundwater flow model, as described in Wurstner et al. (1995), was calibrated using a statistical inverse method as implemented in the CFEST Inverse (CFEST-INV) code. This code was designed to be compatible with CFEST and includes algorithms to calibrate the flow model to prior (measured) hydrogeologic parameters such as head, boundary conditions, and hydraulic conductivity or transmissivity. The code can be applied to calibrate a single-layer areal $(x-y)$ model or a multilayered 
vertical $(x-z$ or $x-y-z)$ model. Insufficient data were available to calibrate the three-dimensional model directly, so the two-dimensional model was calibrated first. The resulting distribution of transmissivity was transferred to the three-dimensional model based on knowledge of subsurface hydrogeology. The procedures for calibrating the two-dimensional model and transferring the results to the three-dimensional model are described in Wurstner et al. (1995).

In the previous application of CFEST-INV to the Hanford Site's unconfined aquifer data set, the code was applied so that only the heads were constrained. The transmissivities were not constrained, and as a result, reached unrealistic values (greater than $10,000,000 \mathrm{~m}^{2} / \mathrm{d}$ ) near Gable Mountain Pond.

Consequently, the calibration of the two-dimensional model was reevaluated in FY 1997. The same 1979 time period, hydraulic head data, finite-element grid, boundary conditions, and artificial and natural recharges reported in Wurstner et al. (1995) were used in the recalibration effort. As previously described (see Section 3.1.1), Cold Creek Valley was treated as a constant-head boundary (148 m) for model calibration. Dry Creek Valley was treated as a constant-flux boundary $\left(1,333 \mathrm{~m}^{3} / \mathrm{d}\right)$. In refining the inverse calibration, the initial transmissivities were adjusted by hand near Gable Mountain and B Ponds to be closer to the final calibrated distribution. A few of the transmissivity zones were adjusted to better reflect the trends in transmissivity developed in previous calibration efforts by Jacobson and Freshley (1990) and Cearlock et al. (1975).

The inverse calibration was performed in several steps to constrain the solution. The starting conditions were adjusted to be much closer to the final solution, and some transmissivity zones were modified to better reflect the distribution of transmissivity in the unconfined aquifer. The resulting transmissivity distribution is illustrated in Figure 4.1, and the hydraulic head solution predicted with the calibrated model is compared with the interpreted water table for 1979 in Figure 4.2. The inverse transmissivities vary from less than 250 to $125,000 \mathrm{~m}^{2} / \mathrm{d}$. The average value is $6,780 \mathrm{~m}^{2} / \mathrm{d}$. This is consistent with the range of transmissivities from the inverse calibration by Jacobson and Freshley (1990); the maximum transmissivity for their calibration that included areal recharge was $112,000 \mathrm{~m}^{2} / \mathrm{d}$.

The hydraulic head distribution predicted with the calibrated model demonstrates good agreement with observed (measured) water levels over much of the site. Areas where agreement is poor include the gap between Gable Butte and Gable Mountain and between the 200-West Area and the boundary at Cold Creek Valley. In the latter region, the interpreted gradient is steeper than in the calibrated model. 


\subsection{Steady-State Three-Dimensional Flow Model Development and Calibration}

The three-dimensional flow model was developed and calibrated based on the two-dimensional inverse transmissivities. Data on the hydrogeology of the individual layers in the model were preserved in the calibration. As in Wurstner et al. (1995), the database of geologic and hydrologic information was developed to be independent of the model grid. Thus, modifications to the finite-element grid (see Figure 3.2) can be made and the data resampled easily. This feature facilitated construction of the threedimensional flow model.

To develop the regional numerical model of the Hanford Site, the Geological Finite-Element Synthesis Tool (GEOFEST) described in Foley et al. (1995) was used to transfer the interpreted water table and the extent and thickness of major hydrogeologic layers as input to CFEST. Bottom elevations of layers, elevation of the water table, and grids representing hydraulic conductivity zones were put into GEOFEST. The hydrogeologic structure represented in the numerical model is described in Wurstner et al. (1995).

The three-dimensional numerical model described in Wurstner et al. (1995) includes the nine hydrogeologic units above the basalt. The basalt layer (unit 10) described in the conceptual model of Wurstner et al. (1995) was excluded from the numerical model over most of the model area to reduce the number of nodes and, consequently, the model run times. The exception was for an area in the vicinity of the basalt outcrops at Gable Mountain and Gable Butte. A limited amount of basalt was retained in these areas so that the model could resolve the location of the intersection of the water table with basalt subcrops as the water table drops in response to the eventual cessation of Hanford discharges to the aquifer.

To further minimize the number of nodes and elements and model nun times, two additional refinements and modifications were made:

- The elevation of the top of Unit 8 (Lower Mud Sequence) was defined as the base of the model in the southeast corner of the modeled area. This was done because the lowest water-bearing unit (Basal Ringold or Unit 9) is not present in this area (see Figure 2.12 in Wurstner et al. 1995). This modification eliminated nodes and elements previously used to describe flow in Unit 8. 
- The elevation of the top of Unit 8 (Lower Mud Sequence) was also defined as the base of the model in the area north of Gable Mountain and Gable Butte. This was done because the lowest water-bearing unit (Basal Ringold or Unit 9) is hydraulically isolated from units above by the low permeability of Unit 8, which is more extensive in this area than Unit 9 (see Figure 2.12 and 2.14 in Wurstner et al. 1995). This modification eliminated nodes and elements previously used to describe flow in Units 8 and 9.

\subsubsection{Hydraulic Properties}

Hydraulic conductivities were assigned to model layers based on data from aquifer pumping tests, slug tests, and some laboratory tests as described in Wurstner et al. (1995). Because data for each of the units are sparse, the general distribution of the inverse calibrated transmissivities was preserved during the three-dimensional model calibration.

The transmissivity distribution derived from the two-dimensional inverse calibration was preserved using the following steps:

Step 1. The hydrogeologic structure of the nine major units of the unconfined aquifer was constructed using the calibrated water-table surface predicted with the inverse calibration using the GEOFEST software processing utility.

Step 2. The transmissivity distribution derived from the inverse calibration was distributed among the major conductive hydrogeologic units (i.e., units $1,3,5,7$, and 9) at every node location using the ratios of average values of the major units given in Table 4.1. The hydraulic conductivity of the less conductive mud units (i.e., units $2,4,6$, and 8 ) were assigned the average property values shown in Table 4.1. The transmissivity of these low-permeability units was then calculated using the calculated saturated thicknesses and these average hydraulic conductivity values. The transmissivities of these units were subtracted from the inverse, calibrated transmissivity before it was redistributed among the other water-bearing units (units $1,3,5,7$, and 9). 
Table 4.1. Assumed Hydraulic Conductivities for Major Hydrogeologic Units Used in the Redistribution of Inverse Calibrated Transmissivities to the Three-Dimensional Model

\begin{tabular}{||l|c|c||}
\hline Hydrogeologic Unit & $\begin{array}{c}\text { Estimated Range } \\
\text { of Saturated Hydraulic } \\
\text { Conductivities (m/d) }\end{array}$ & \multicolumn{1}{|c|}{ Reference(s) } \\
\hline Hanford Formation (Unit 1) & 1 to 1,000,000 & $\begin{array}{c}\text { Wurstner et al. (1995): Thome } \\
\text { and Newcomer (1992) }\end{array}$ \\
\hline Palouse Soils (Unit 2) & 0.057 to 0.12*. & Khaleel and Freeman (1995) \\
\hline Plio-Pleistocene Unit (Unit 3) & 0.005 to 17.3*' & Khaleel and Freeman(1995) \\
\hline Upper Ringold Unit (Unit 4) & 0.0003 to 0.09 & $\begin{array}{c}\text { Wurstner et al. (1995); Thorne } \\
\text { and Newcomer (1992) }\end{array}$ \\
\hline Middle Ringold - Unit E (Unit 5) & 0.1 to 200 & $\begin{array}{c}\text { Wurstner et al. (1995); Thorne } \\
\text { and Newcomer (1992) }\end{array}$ \\
\hline Middle Ringold - Unit C (Unit 6) & 0.0003 to 0.09 & $\begin{array}{c}\text { Wurstner et al. (1995); Thorne } \\
\text { and Newcomer (1992) }\end{array}$ \\
\hline Middle Ringold - Unit B and D (Unit 7) & 0.1 to 200 & $\begin{array}{c}\text { Wurstner et al. (1995); Thorne } \\
\text { and Newcomer (1992) }\end{array}$ \\
\hline Lower Ringold Unit (Unit 8) & 0.0003 to 0.09 & $\begin{array}{c}\text { Wurstner et al. (1995); Thorne } \\
\text { and Newcomer (1992) }\end{array}$ \\
\hline Basal Ringold Unit (Unit 9) & 0.1 to 200 & $\begin{array}{c}\text { Wurstner et al. (1995); Thorne } \\
\text { and Newcomer (1992) }\end{array}$ \\
\hline \hline
\end{tabular}

* Data derived primarily from hydraulic analysis of split-spoon samples.

Step 3. The redistributed transmissivities were then used to develop areal distributions of hydraulic conductivities for each major unit, taking into consideration the calculated saturated thickness generated by GEOFEST from the hydrogeologic structure information.

Step 4. The resulting distributions of hydraulic conductivity were combined with the generated hydrogeologic structure of all major units and used as input to a steady-state run with CFEST using the confined aquifer option. Constant-head boundaries used in the inverse calibration were used to hold boundary nodes at and below the water-table surface in the same locations used in the inverse calibration (i.e., Cold Creek Valley, North and East Dry Creek Valleys, and along the Rattlesnake Hills). 
Step 5. The head distribution derived from the previous step was then used to repeat Steps 1 through 4 to arrive at a new calibrated head surface that would reflect the structure and distribution of hydraulic conductivity derived from the original inverse calibrated transmissivity distribution.

Step 6. The model run made in Step 5 was then replicated with CFEST, using the unconfined aquifer option and with the calculated constant fluxes derived at constant-head boundary nodes substituted at constant head nodes. Constant fluxes were the only input to the most significant water-bearing units at the specified boundary-node locations.

Step 7. As a final check, the model run made in Step 6 was then replicated with CFEST, using the unconfined aquifer option and the calculated constant fluxes derived at constant-head boundary nodes substituted at constant head nodes.

Using the steps given above, the final water table and hydraulic conductivity layering combination for the three-dimensional model was determined. Figure 4.4 shows the hydraulic conductivities used for the uppermost hydrogeologic units represented by surface elements in the model. Plots of the steady-state solution from the three-dimensional model for 1979 with the observed 1979 water table, shown in Figure 4.5, provide a comparison of model results with conditions interpreted for 1979. This figure and Figure 4.6, which provides a shaded map of the differences between these two surfaces, shows that in general, predicted water levels throughout most of the modeled region are within a meter or two of observed conditions. A statistical comparison of the difference between the predicted water table and the interpreted water-table surface, summarized in Table 4.2, provides additional information on the goodness of fit at all 1457 surface node locations.

Another measure of goodness of fit is a comparison of predicted water-table elevations with those measured in individual wells. This information is summarized in Figure 4.7, which provides a comparison of predicted versus observed water levels measured at 100 wells. Of the 100 wells plotted in this figure, predicted water levels at comparable locations were within a meter of observed water levels at 85 well locations and well within $5 \mathrm{~m}$ of observed values for all well locations. 


\subsubsection{Flow Boundary Conditions}

Once the three-dimensional model was calibrated, the constant-head boundary conditions used to simulate fluxes for Cold Creek and Dry Creek Valleys and off the Rattlesnake Hills were changed to constant fluxes. Fluxes were distributed over all vertical nodes representing the boundary. The constant flux boundary conditions calibrated from the 1979 steady-state prediction were $2881 \mathrm{~m}^{3} / \mathrm{d}$ for Cold Creek Valley, $1207 \mathrm{~m}^{3} / \mathrm{d}$ for Dry Creek Valley North, $328 \mathrm{~m}^{3} / \mathrm{d}$ for Dry Creek Valley East, and $3104 \mathrm{~m}^{3} / \mathrm{d}$ for the Rattlesnake Hills area. The previous estimate of the Cold Creek boundary condition from the twodimensional inverse calibration by Jacobson and Freshley (1990) was $8805 \mathrm{~m}^{3} / \mathrm{d}$, and the estimate made with VAM3D by Law et al. (1996) was $10368 \mathrm{~m}^{3} / \mathrm{d}$. The estimate of this same flux for the Variable Thickness Transient (VTT) flow model by Kipp et al. (1972) was $9104 \mathrm{~m}^{3} / \mathrm{d}$. The current estimate for Cold Creek $\left(2881 \mathrm{~m}^{3} / \mathrm{d}\right)$ is lower than previous estimates.

The flux at the Rattlesnake Hills boundary condition previously estimated with the two-dimensional inverse calibration by Jacobson and Freshley (1990) was $1331 \mathrm{~m}^{3} / \mathrm{d}$, and the estimate made with VTT by Kipp et al. (1972) was $3105 \mathrm{~m}^{3} / \mathrm{d}$. The flux used in the model by Jacobson and Freshley (1990) accounted for the boundary influx at the east valley of Dry Creek. In the model by Law et al. (1996), the flux along Rattlesnake Hills was assumed to be negligible. The current estimate for Rattlesnake Hills $\left(3104 \mathrm{~m}^{3} / \mathrm{d}\right)$ is lower than previous estimates.

A previous estimate for the Dry Creek Valley boundary from the model by Law et al. (1996) in which a boundary flux used was about $44,064 \mathrm{~m}^{3} / \mathrm{d}$. The current estimate for both the north and east valleys of Dry Creek $\left(1535 \mathrm{~m}^{3} / \mathrm{d}\right)$ is significantly lower than this previous estimate.

In the three-dimensional model, the prescribed head for the Columbia River boundary was held constant at nodes located at the left edge of the river shore (looking upstream) and the node located in the middle of the river channel. Nodes located vertically below the node positioned in the middle of the river were assigned as no-flow boundaries. This was done to approximate the broad boundary of lateral and vertical discharge from the unconfined aquifer through the bed of the river, which is assumed to be a point of discharge for water and contaminants flowing toward the river from both the Hanford Site and Franklin County shorelines. 
Table 4.2. Statistical Comparison of Differences Between Observed and Predicted 1979 Water-Table Elevations

\begin{tabular}{||l|c||}
\hline Statistical Categories & Values, in meters \\
\hline All Nodes (1457 nodes) & 5.13 \\
\hline Maximum Error & -6.73 \\
\hline Minimum Error & -0.63 \\
\hline Average Error & 1.08 \\
\hline Absolute Value of Error & 1.64 \\
\hline RMS of Error & \\
\hline Nodes with Positive Errors (509 nodes) & 0.65 \\
\hline Average Error & 0.93 \\
\hline RMS of Error & \\
\hline Nodes with Negative Errors (948 nodes) & -1.31 \\
\hline Average Error & 1.91 \\
\hline RMS of Error & \\
\hline
\end{tabular}

The distribution of natural recharge estimated by Fayer and Walters (1995) for 1979 (see Figure 3.1) was used as input for both the steady-state and transient-flow models. This distribution of natural recharge was assumed to remain constant during the entire simulation period. In reality, fires, land use, and natural progression of the ecosystem will change the distribution of vegetation types and, thus, future recharge conditions.

\subsection{Three-Dimensional Transient-Flow Model Calibration and Application}

This section of the report describes the overall approach and results for 1) the transient calibration of the three-dimensional model from 1979 to 1996 conditions, and 2) the application of the threedimensional model to simulating transient-flow conditions in the unconfined aquifer from 1996 to the year 4000 . The simulation of transient-flow conditions provided the hydraulic framework and conditions used to make long-term forecasts of contaminant plumes currently being transported in the unconfined aquifer system. 


\subsubsection{Transient Calibration of 1979 to 1996 Conditions}

After generating a reasonable steady-state solution for the three-dimensional model, the response of the model to transient flux input (e.g., B Pond waste discharges) was calibrated. Transient simulations with the two- and three-dimensional flow models required data on artificial recharge. Artificial recharge was applied at the nearest node to the actual discharge site. The artificial recharge values used in the transient-flow models and the Rattlesnake Mountain spring discharges are summarized in the Appendix (Table A.1). The yearly totals of all artificial recharge to the 200 Areas as a function of time are shown in Figure 4.8. Beyond 1995, the only facilities that are projected to discharge waste water to the unconfined aquifer are W-049H (the 200 Areas Treated Effluent Disposal Facility [TEDF]), SALDS, and the Richland North Area well field. The City of Richland recharges the groundwater with Columbia River water at the Richland North Area well field so that groundwater is available for withdrawal when the river pumping station is shut down for maintenance or additional water is needed to meet irrigation demands. As seen in Figure 4.8, discharges to the TEDF cease after the year 2026.

A number of calibration simulations were performed to evaluate the appropriate specific yield value to achieve the best overall match. The storage properties of the aquifer (specific yield) control how the model responds to changes in flux. Wurstner et al. (1995) estimated the range for specific yield of Unit 1 to be from approximately 0.1 to 0.3 .

Three-dimensional transient simulations were conducted for the time frame from 1980 to 1995 using specific yields ranging from 0.1 to 0.35 . The simulations used semi-annual time steps, semi-annual watertable updates, and yearly averaged fluxes. The best fit to the observed data was achieved when a specific yield of 0.1 was used where the Ringold Formation is found, and a specific yield of 0.25 was used where the Hanford Formation is found. The comparison of predicted with observed conditions for 1996 using this combination of specific yields is shown in Figure 4.9. Figures 4.10 through 4.14 show hydrographs comparing the model results with observed heads from 1979 to 1996 for 20 groups of wells. Figure 4.15 shows the locations of the wells used in the hydrographs.

\subsubsection{Simulation of Future Transient Conditions}

Past analyses of post-Hanford unconfined aquifer conditions have considered land uses that could significantly alter the long-term behavior of the unconfined aquifer beneath the Hanford Site. An example 
of such use is large-scale irrigation of the Site, postulated for certain agricultural purposes. The potential for large-scale agricultural irrigation occurring on the Hanford Site in the future was also examined. Based on consultations with staff from the Agricultural Research Service at the Agricultural Experiment Station in Prosser, Washington, large-scale irrigation on the Hanford Site is considered to be unlikely for a variety of factors, including

- uncertainty regarding the public's acceptance of food products grown on the Hanford Reservation, regardless of the actual risk associated with agricultural development at the Site

- the unavailability of sufficient water rights within the Columbia Basin for developing crops that require large-scale irrigation on the Site. If agriculture should develop on the Site, it is more likely that crops which use more efficient and focused irrigation methods (e.g. drip irrigation), such as that used in fruit orchards or vineyards, will be selected

- the use of new technologies and advanced resource management practices that will likely eliminate or significantly curtail overwatering practices.

Because of these conclusions regarding potential irrigation on the Hanford Site, projections of postHanford water-table conditions in this study focused mainly on predicting the impact of Hanford operations ceasing and the resulting changes in artificial discharges that have been used extensively as a part of site waste-management practices. Simulations of transient-flow conditions from 1996 through the year 4000 were conducted with the three-dimensional model using the distribution of hydraulic conductivities from the steady-state calibration and the distribution of specific yields developed from the transient calibration ( 0.25 for Hanford Formation and 0.1 for the Ringold Formation). The same natural recharge distribution that was used in the steady-state calibration was used in these future conditions simulations. A comparison of the initial conditions for this simulation with observed values was provided earlier in Figure 4.5. The water tables estimated with the three-dimensional model for the years 2000 , 2100,2200 , and 2350 (Figures 4.16 through 4.19 ) show an overall decline in the hydraulic head and hydraulic gradient across the entire water table within the modeled region. From the selected hydrographs shown in Figures 4.20 through 4.24 , it can be observed that the different areas approach steady state with different rates of time. The areas along the Columbia River north of the gap between Gable Butte and Gable Mountain (areas 17 and 19 in Figure 4.24) have the shortest response times, and water levels in this 
region reach steady state by the year 2100. The area between Gable Butte and Gable Mountain (areas 18 and 20 in Figure 4.24) reach steady-state conditions sometime between the years 2200 and 2300. Area 3 (Figure 4.20) has the slowest response time, and water levels in this area reach steady-state conditions only after 2400 . The remaining areas plotted in Figures 4.20 through 4.24 , including the area south of Gable Mountain and east of the 200-West Area plateau, all reach steady-state conditions between the years 2300 and 2350 .

Flow modeling results also suggest that as water levels drop in the vicinity of central areas in the model where the basalt crops out above the water table, the saturated thickness of the unconfined aquifer greatly decreases and the aquifer may actually dry out. This thinning/drying of the aquifer is predicted to occur in the area between Gable Butte and the outcrop south of Gable Mountain, resulting in the northern area of the unconfined aquifer becoming hydrologically separated from the area south of Gable Mountain and Gable Butte. Therefore, flow from the 200-West Area and the northern half of the 200-East Area, which currently migrates through the gap between Gable Butte and Gable Mountain, will be effectively cut off in the next 200 to 300 years. In time, the overall water table (including groundwater mounds near the 200-East and -West Areas) will decline, and groundwater movement from the 200-Area plateau will shift to a dominantly west-to-easterly pattern of flow toward points of discharge along the Columbia River between the Old Hanford townsite and the Washington Public Power Supply System facility.

The decline in the water table from current conditions (January, 1997) to those predicted in the year 2350 is shown in Figure 4.25. In the 200-East Area, the maximum change in head is realized in the area of a current groundwater mound where the water table drops between 4 and $6 \mathrm{~m}$. In the 200-West Area, model results indicate a maximum drop in the water table of about $11 \mathrm{~m}$ during this same period.

As a qualitative measure of the appropriateness of the predicted water table estimated with the threedimensional model, the predicted water table for post-Hanford conditions for the year 2350 was compared to estimated water-table conditions in 1944 provided in Kipp and Mudd (1974) and shown in Figure 4.26. In general, the water table predicted for post-Hanford conditions agreed favorably with that estimated for 1944 conditions for the central part of the Hanford Site and the area north of Gable Mountain and Gable Butte. However, model results indicated a much different water table than was estimated for pre-Hanford conditions. This is apparent in two areas: 1) the area west of the 200-Area plateau, where higher predicted hydraulic heads reflect boundary conditions that consider the effect of irrigation from areas outside of the modeled region, and 2) the area north of Richland, where the model simulates the hydraulic effect of the 
effect of the North Richland well field. Discrepancies in these two areas of the water-table surface may be attributable to one or more of the following factors:

- The estimated water table for pre-Hanford conditions was developed based on back-extrapolation of well hydrograph data and previous maps developed by Newcomb et al. (1972) and Biershenck (1957). Most of the sites used were irrigation wells primarily in the eastern half of the site and in the area north of Gable Mountain and Gable Butte. Only a few wells were available west of the 200-East Area. Thus, because of little well control, the interpretation of the water table, particularly in the western portion of the site, may not reflect actual conditions.

- Boundary conditions used in the model in the Cold Creek and Dry Creek Valleys consider groundwater flow from regions upgradient of the site that have received substantially more irrigation than probably existed prior to Hanford Site operations.

- The predicted water table is based on a distribution of hydraulic conductivity that exhibits a rapid increase in hydraulic conductivity in the aquifer along the contact of the Ringold and Hanford Formations between the 200-East and 200-West Areas. The steep hydraulic gradients in the westcentral part of the Hanford Site are reflective of the lateral change in hydraulic conductivity used in the model. 


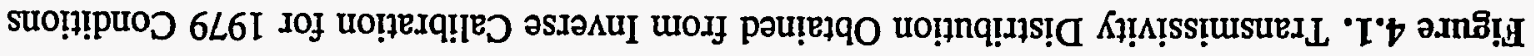

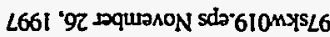

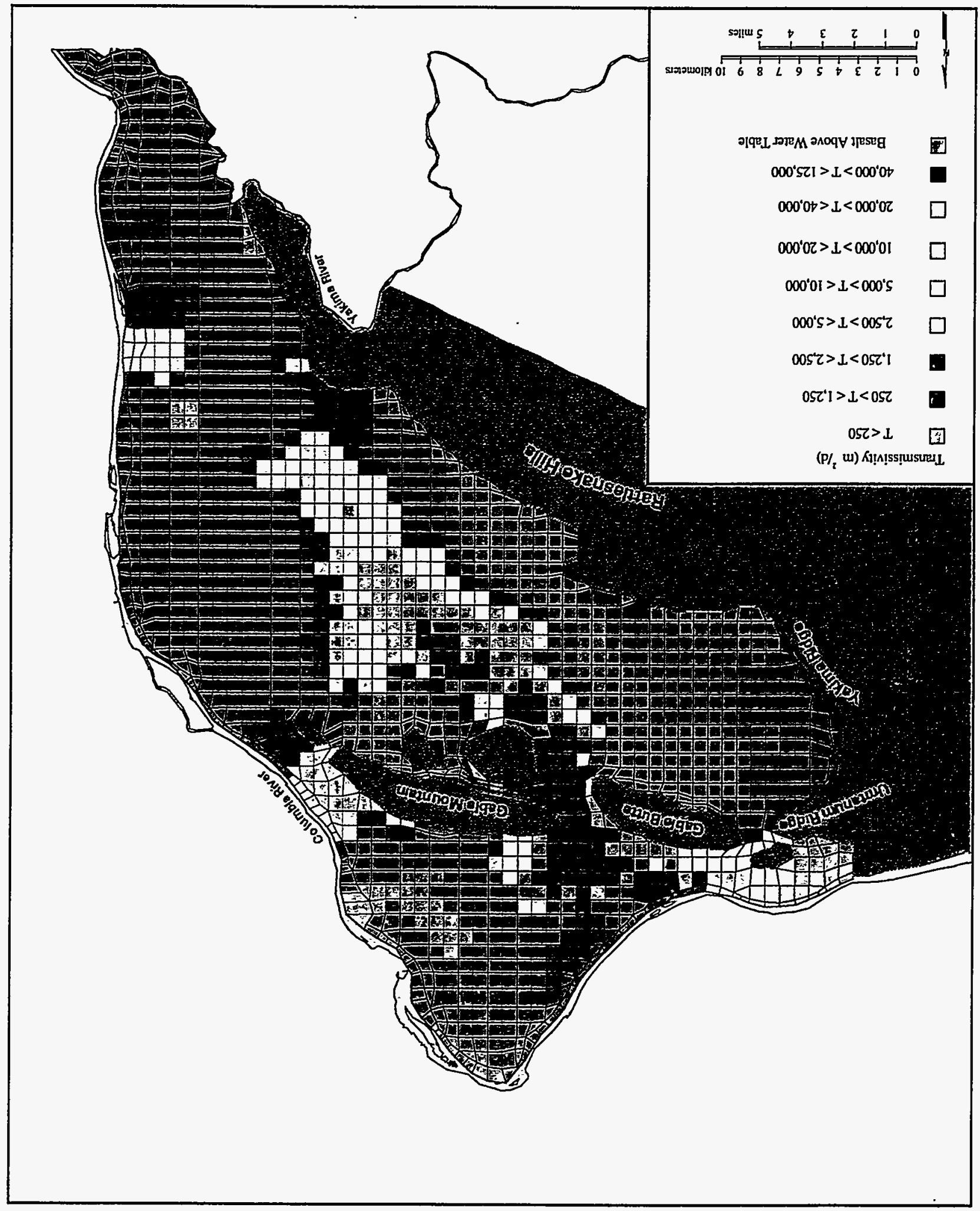




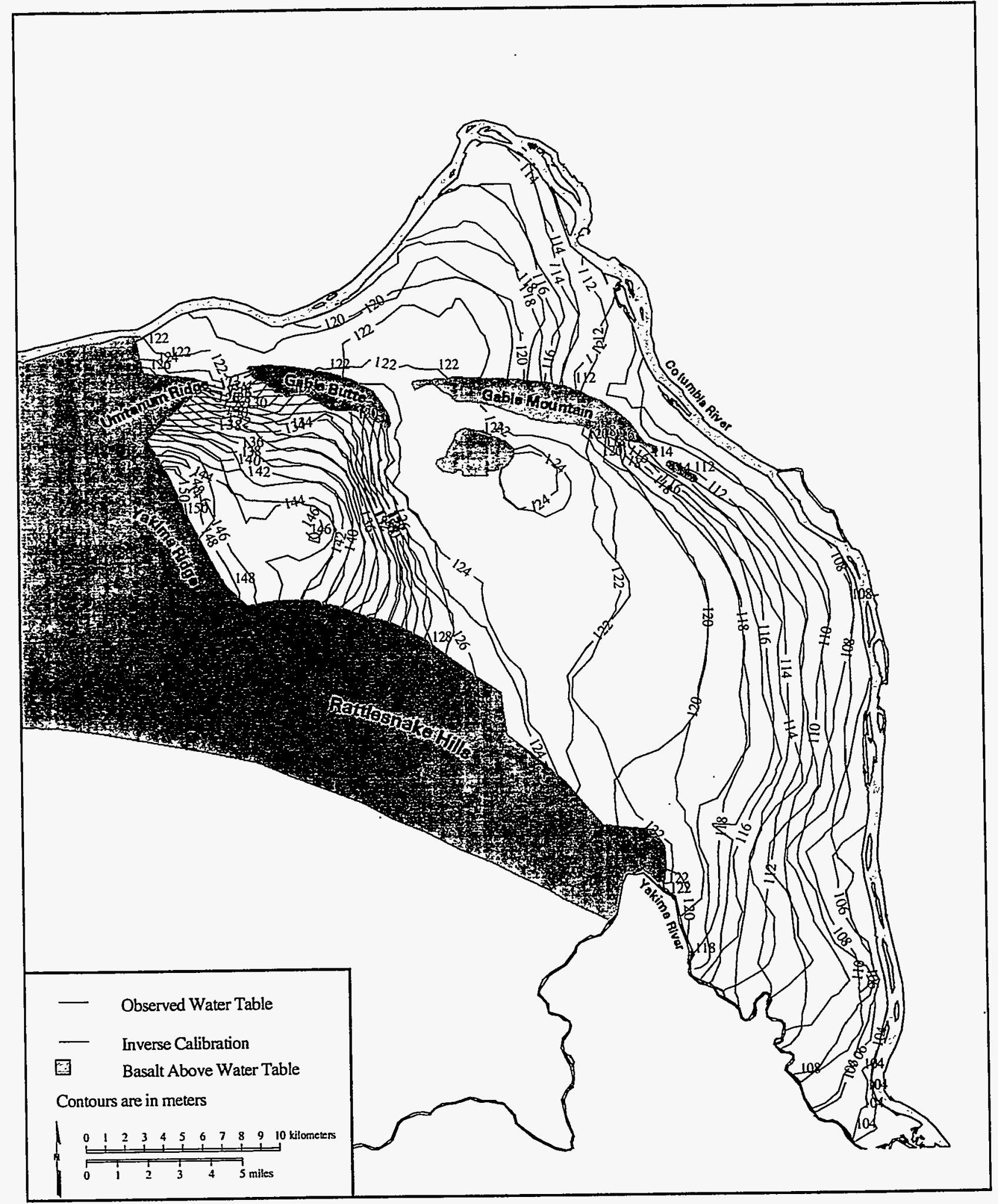

97skw020.eps November 26. 1997

Figure 4.2. Comparison of Observed and Predicted Water-Table Conditions for 1979 from the Two-Dimensional Model Using Transmissivities from the Inverse Calibration 


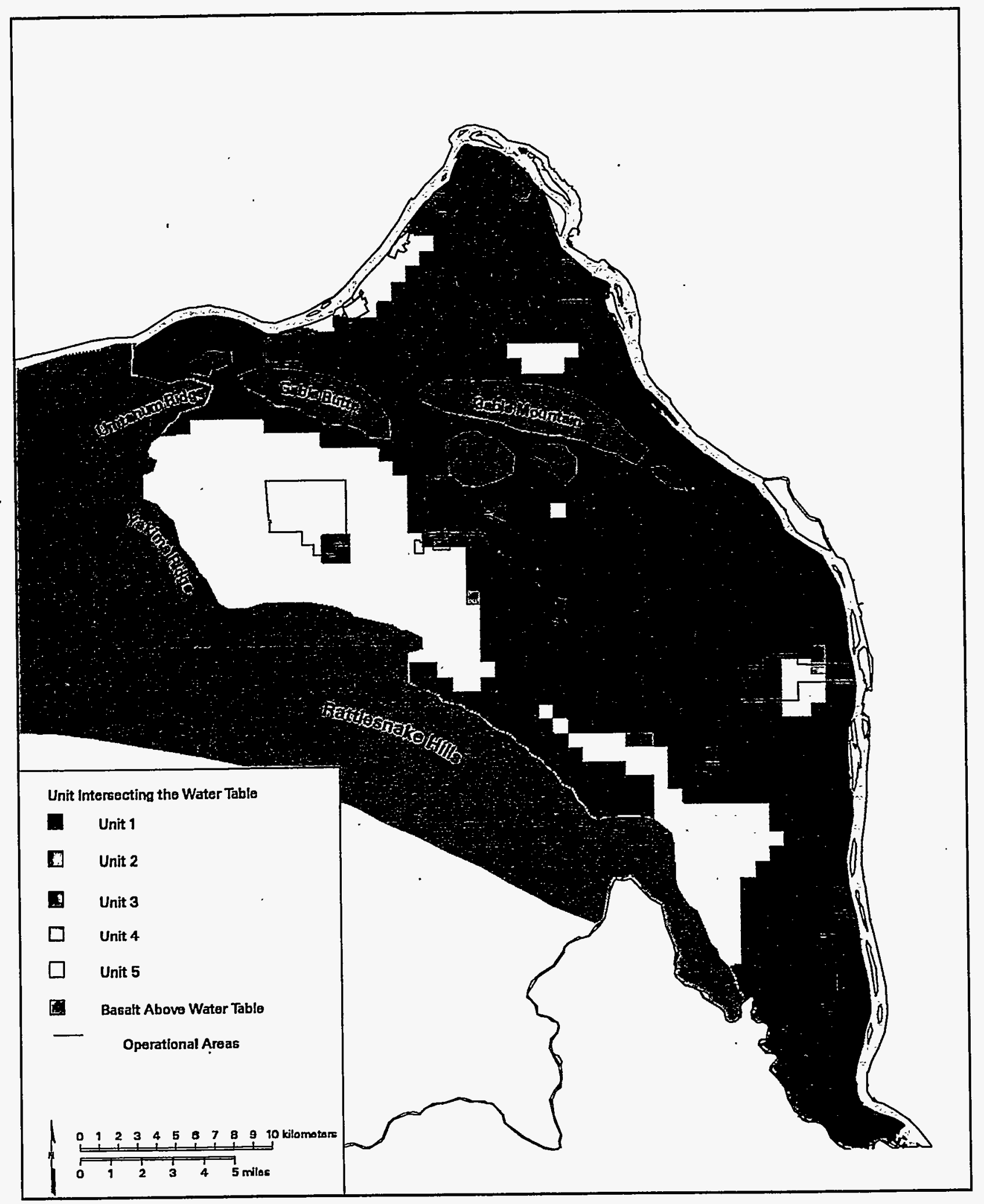

97skw021.eps October 21, 1997

Figure 4.3. Hydrogeologic Units Intersecting Water Table for 1979 Conditions 


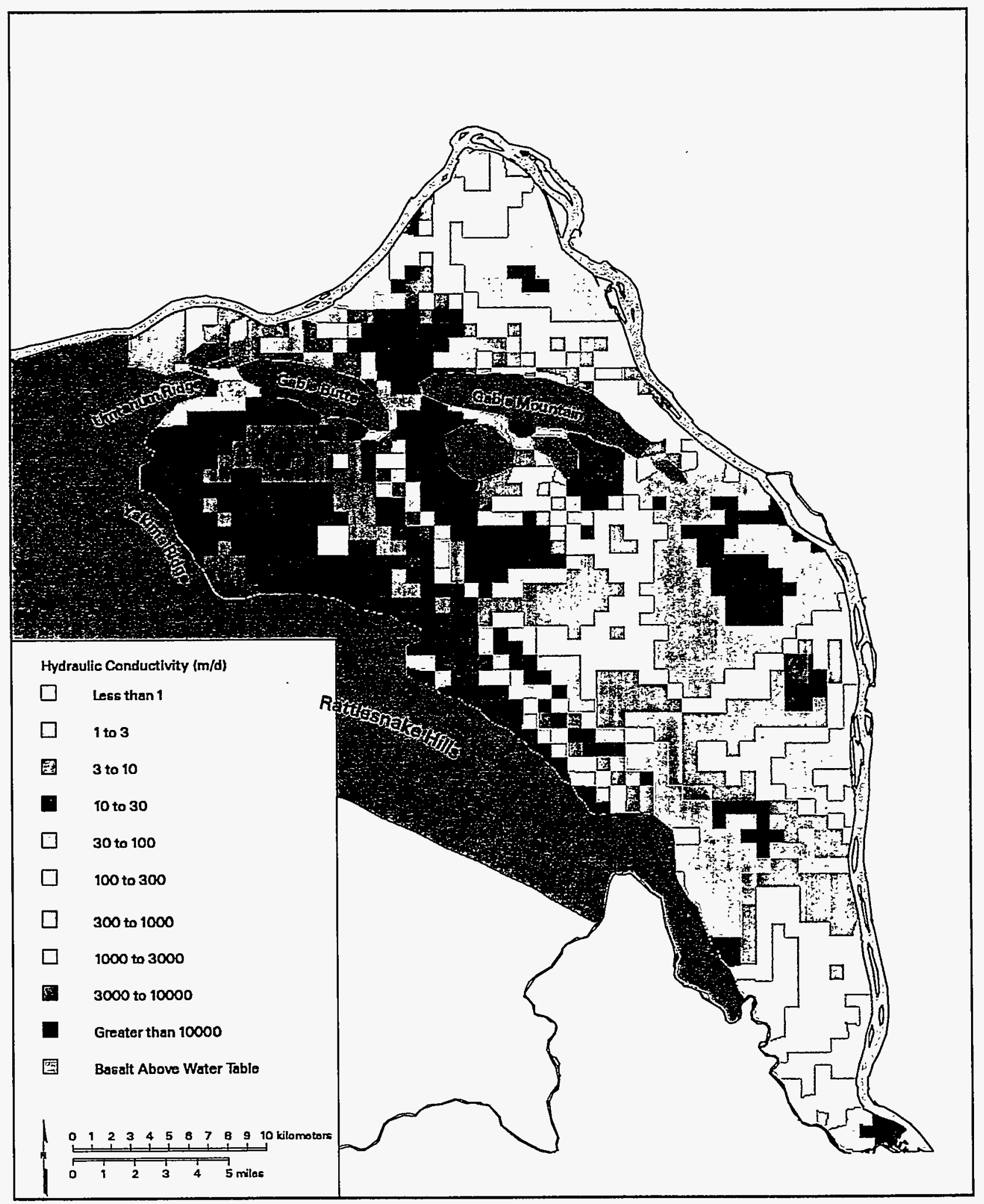

97skw022.cps October 21, 1997

Figure 4.4. Hydraulic Conductivity Distribution in the Uppermost Hydrogeologic Units of the Three-Dimensional Model 


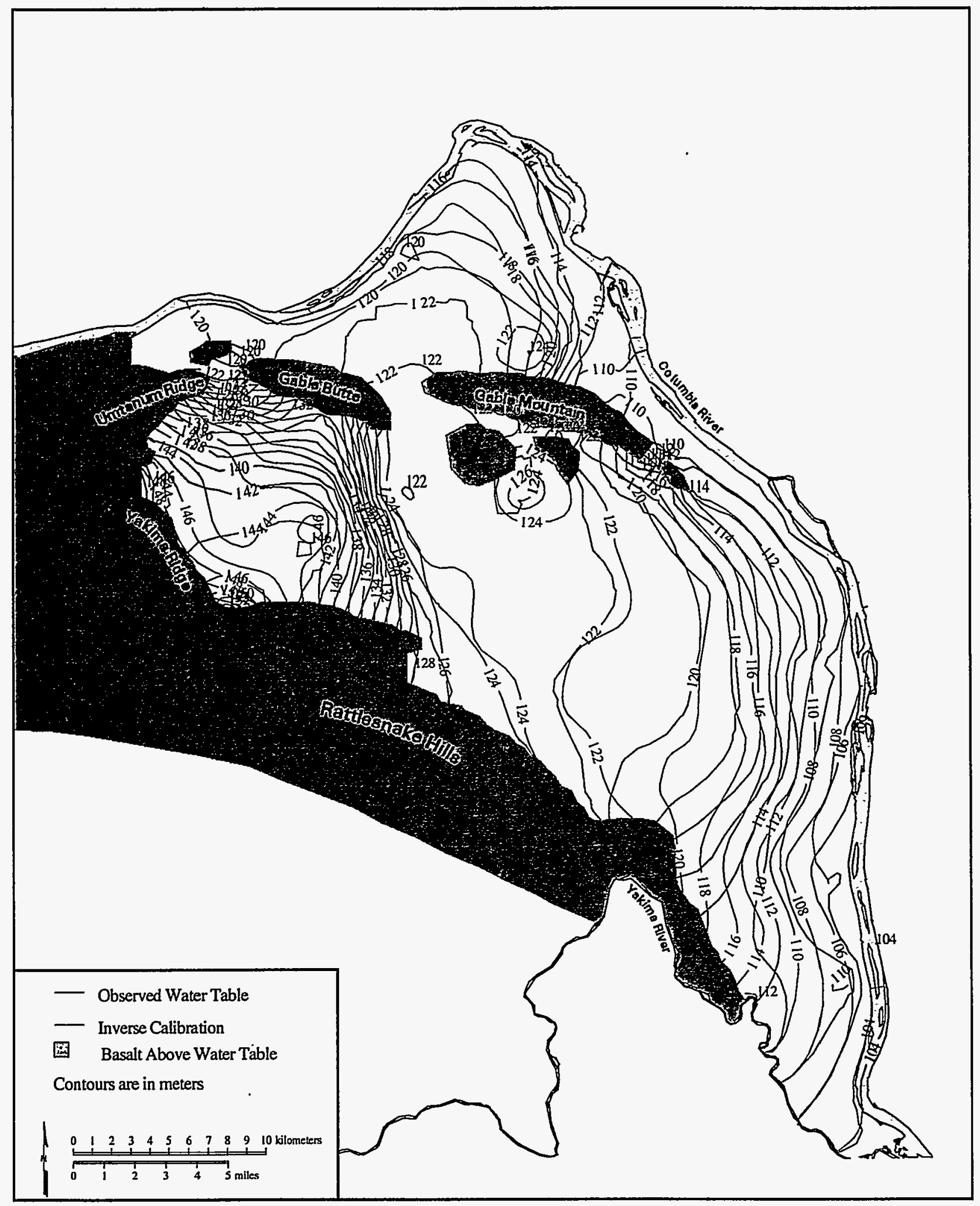

97skw023.eps November 26. 1997

Figure 4.5. Comparison of Observed and Predicted Water-Table Conditions for 1979 Using the Three-Dimensional Model 


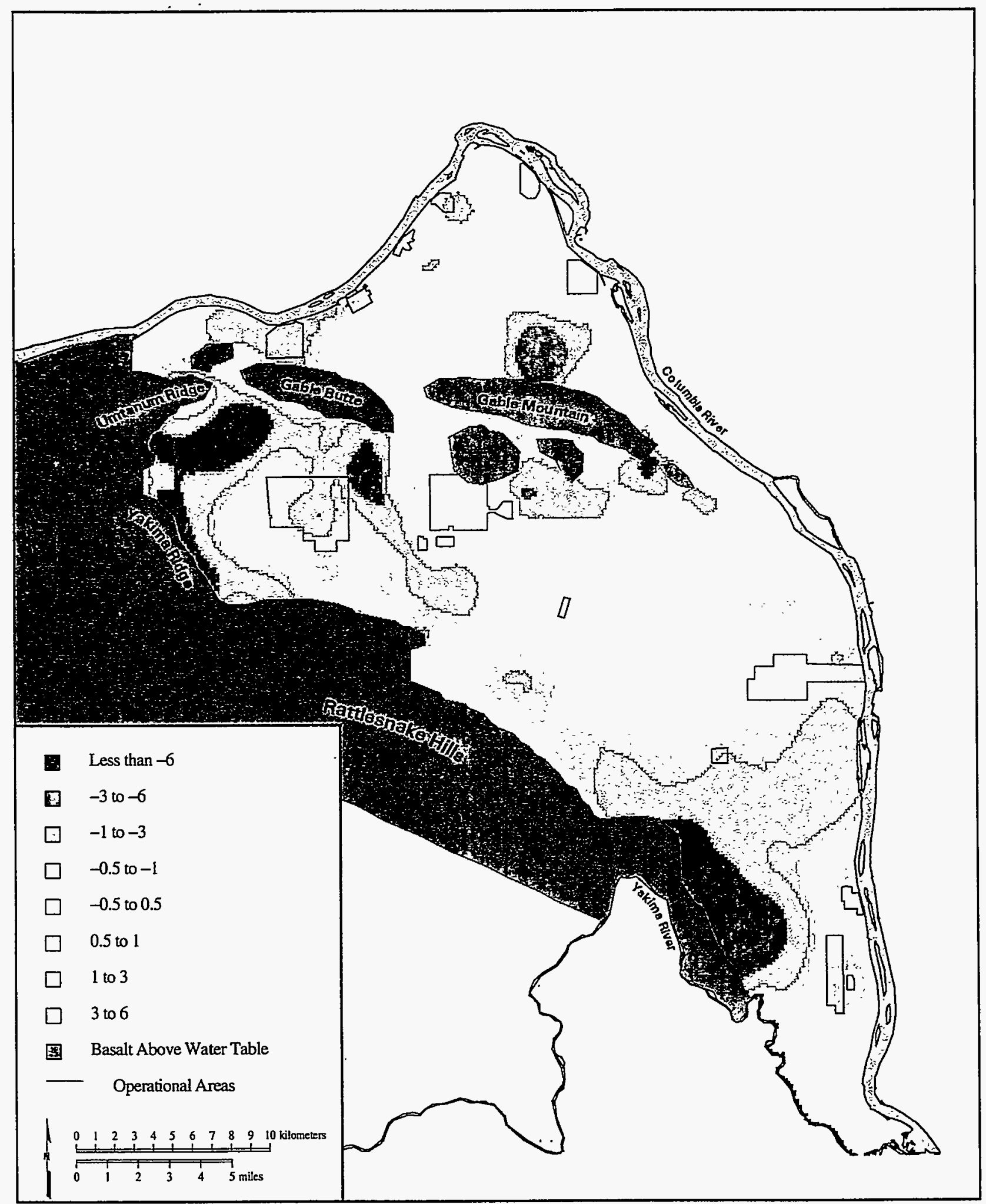

97skw024.eps December 29, 1997

Figure 4.6. Difference Between the Observed Water Table and the Water Table Predicted for 1979 with the Three-Dimensional Model 


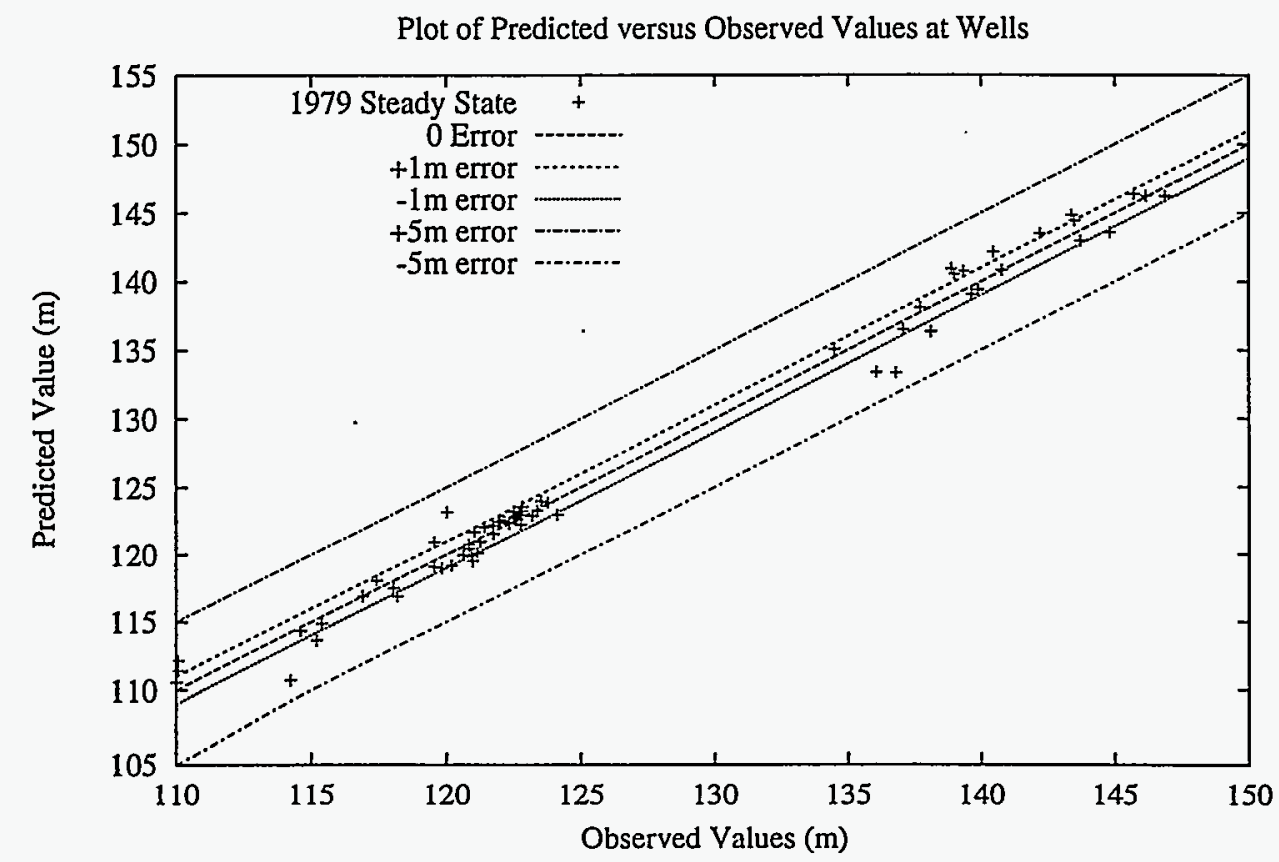

Figure 4.7. Comparison of Water-Table Elevations Measured in Wells and Water-Table Elevations Predicted for 1979 with the Three-Dimensional Model 


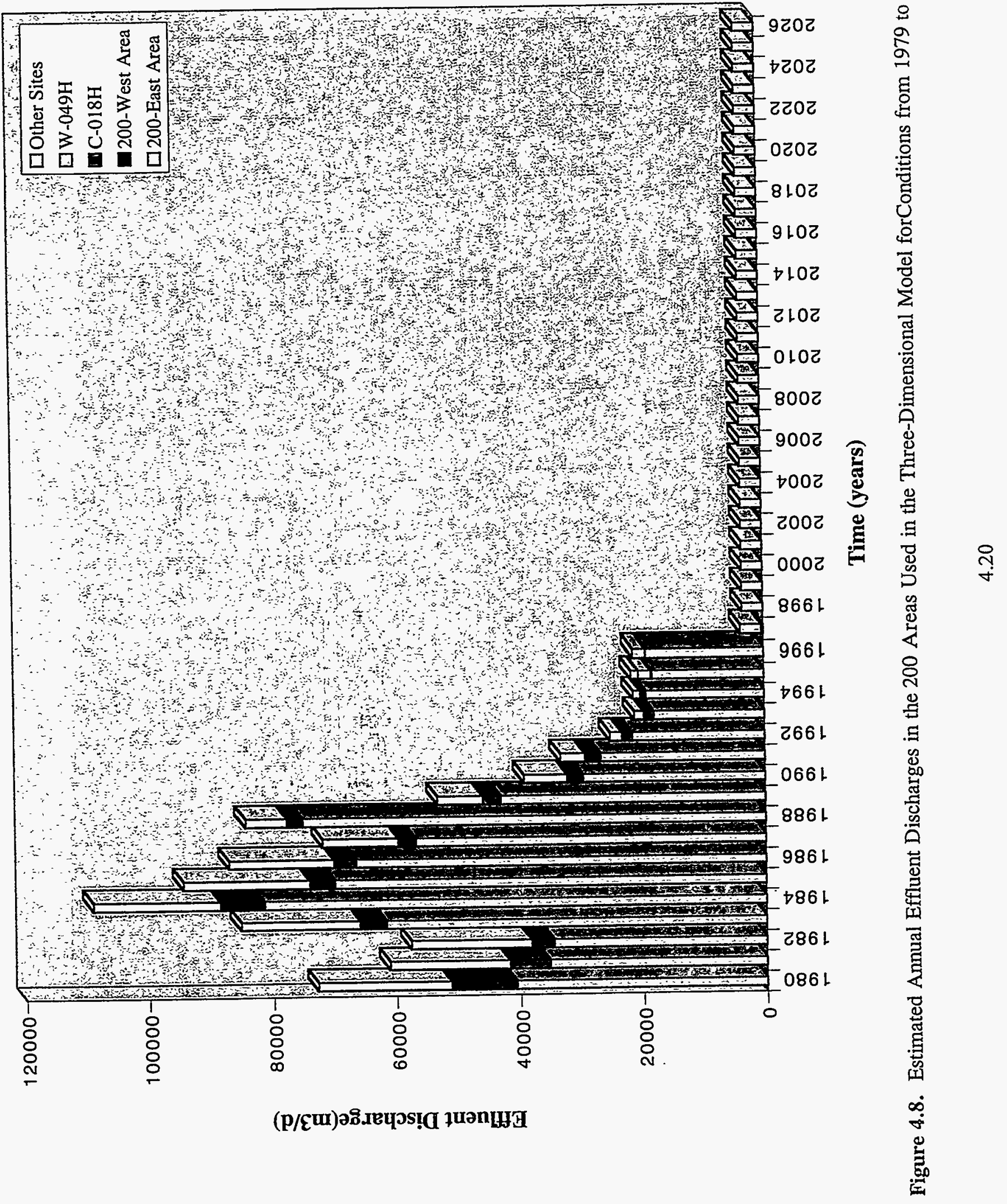




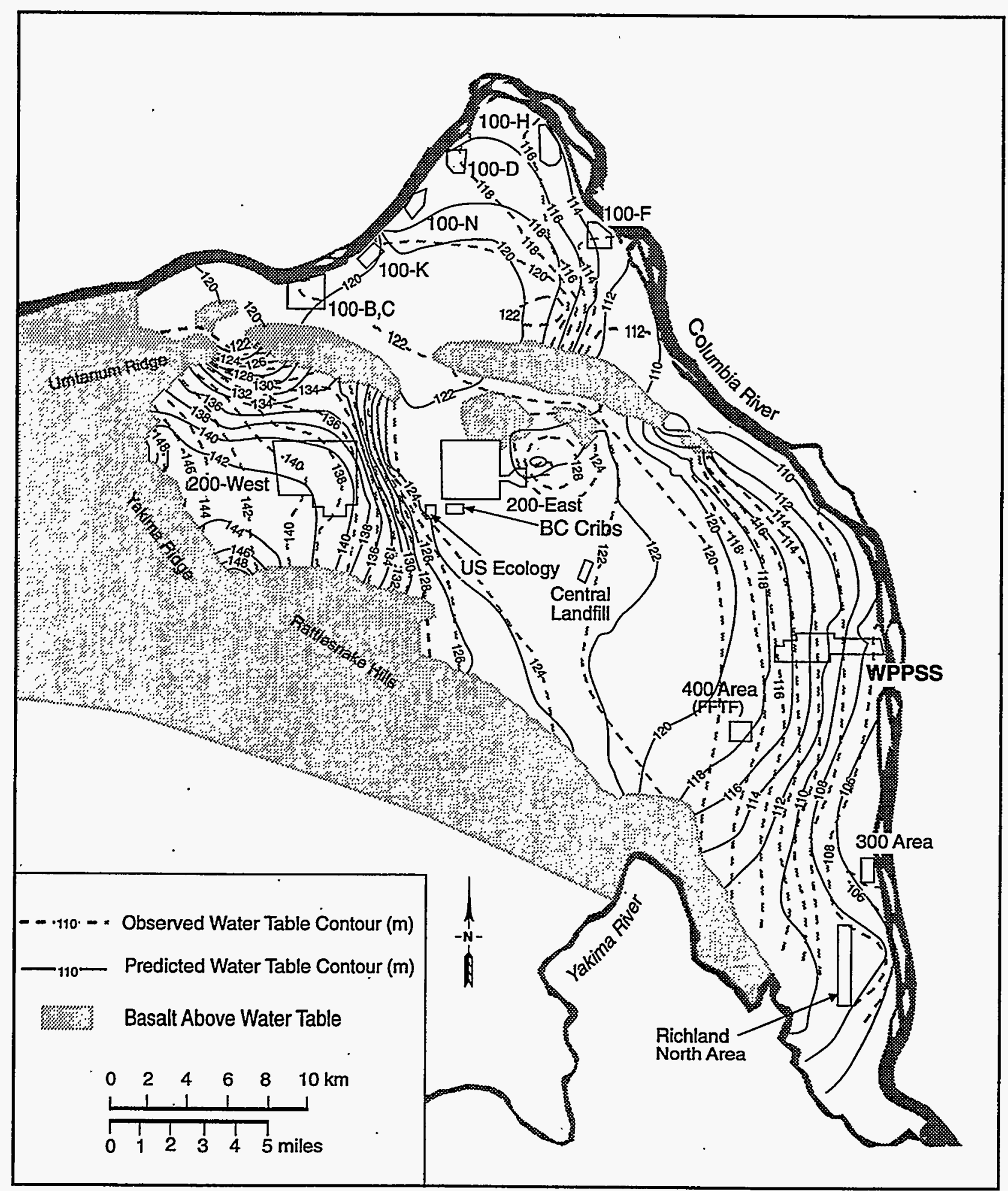

SP97120015.1

Figure 4.9. Comparison of 1996 Observed and Predicted Water Table Conditions Using Specific Yield of 0.1 for the Ringold Formation and 0.25 for the Hanford Formation. 

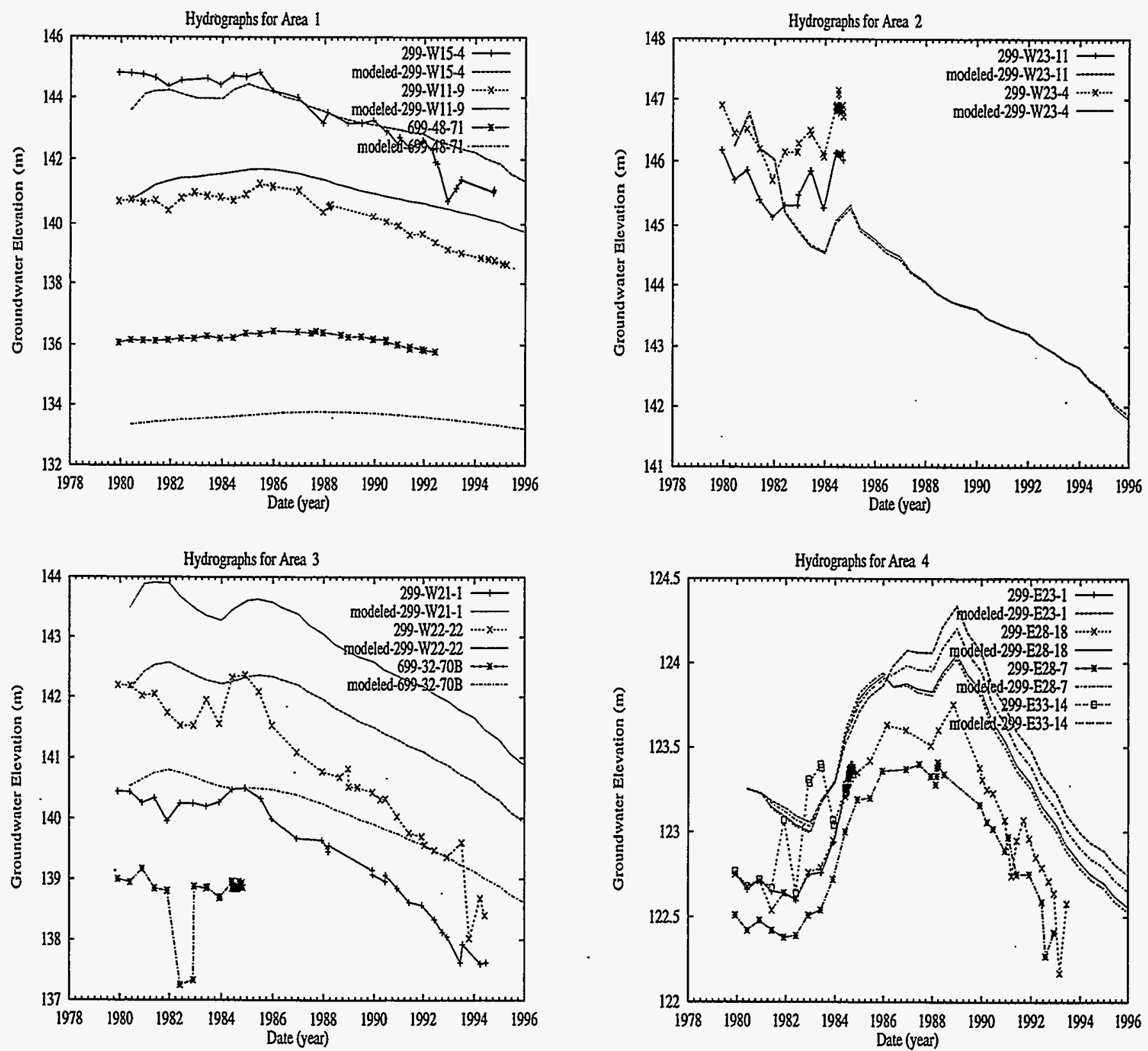

Figure 4.10. Hydrographs for Selected Wells and Model Nodes in Areas 1, 2, 3, and 4 from 1979 to 1996 

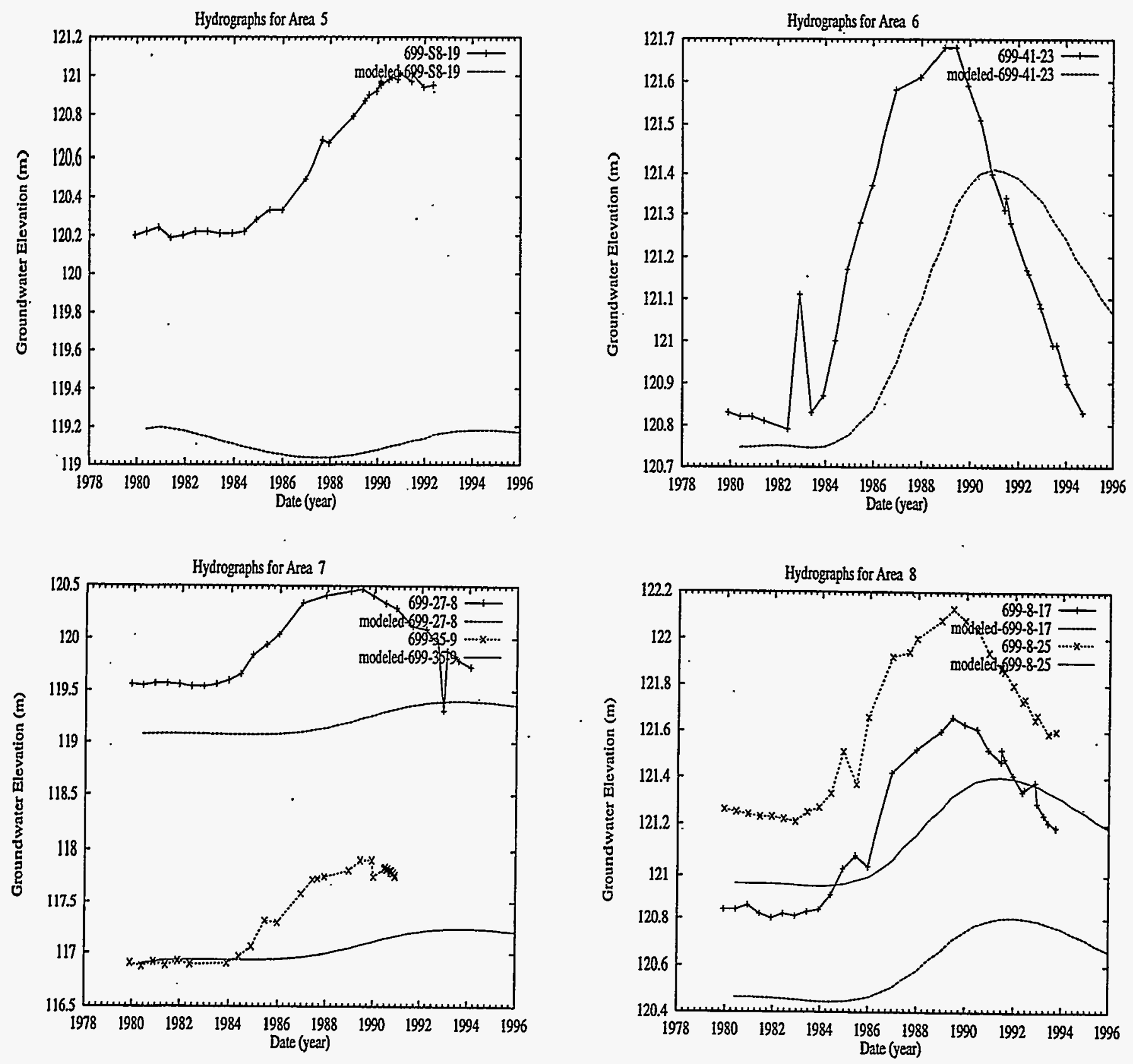

Figure 4.11. Hydrographs for Selected Wells and Model Nodes in Areas 5, 6, 7, and 8 from 1979 to 1996 

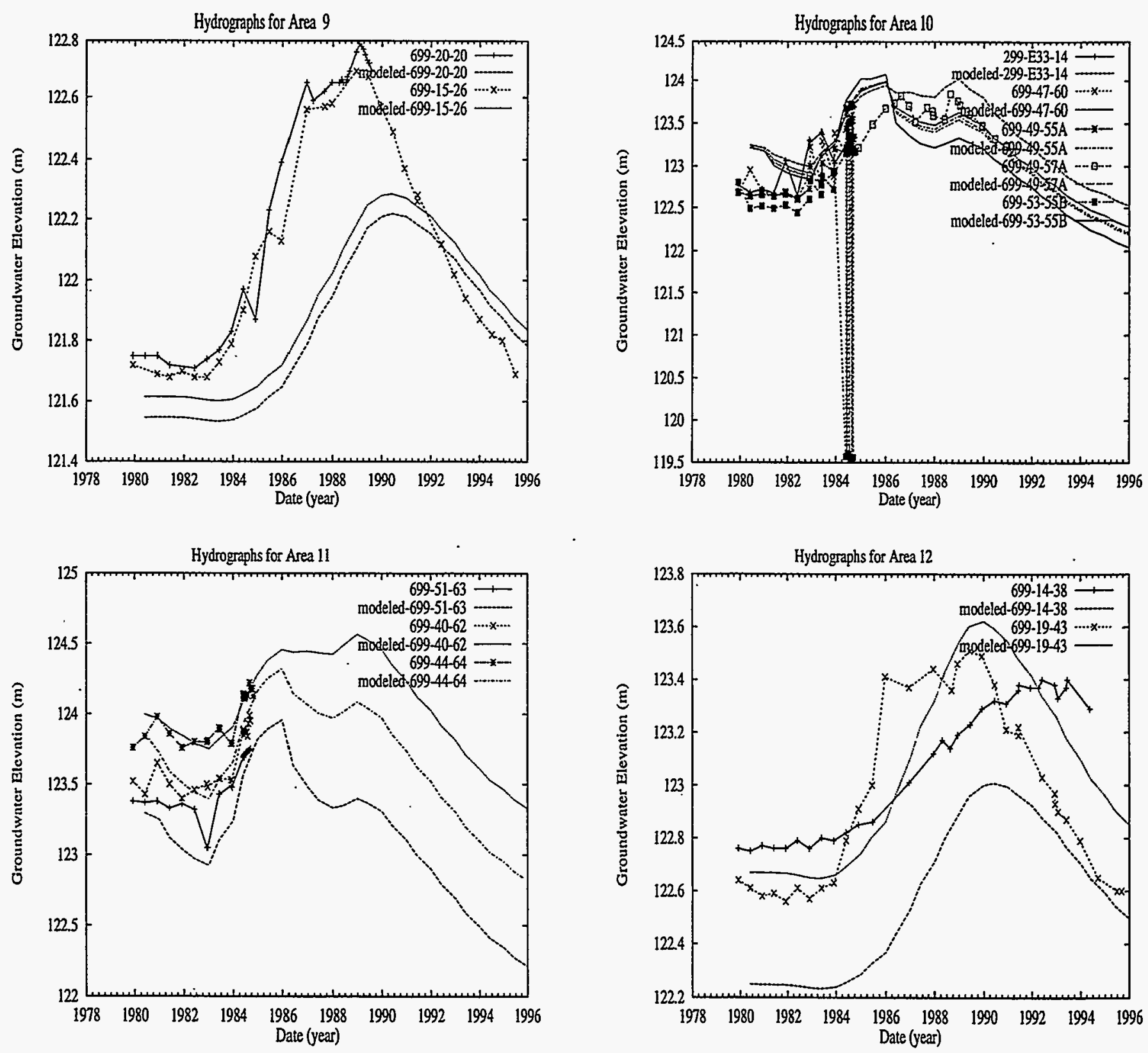

Figure 4.12. Hydrographs for Selected Wells and Model Nodes in Areas 9, 10, 11, and 12 from 1979 to 1996 

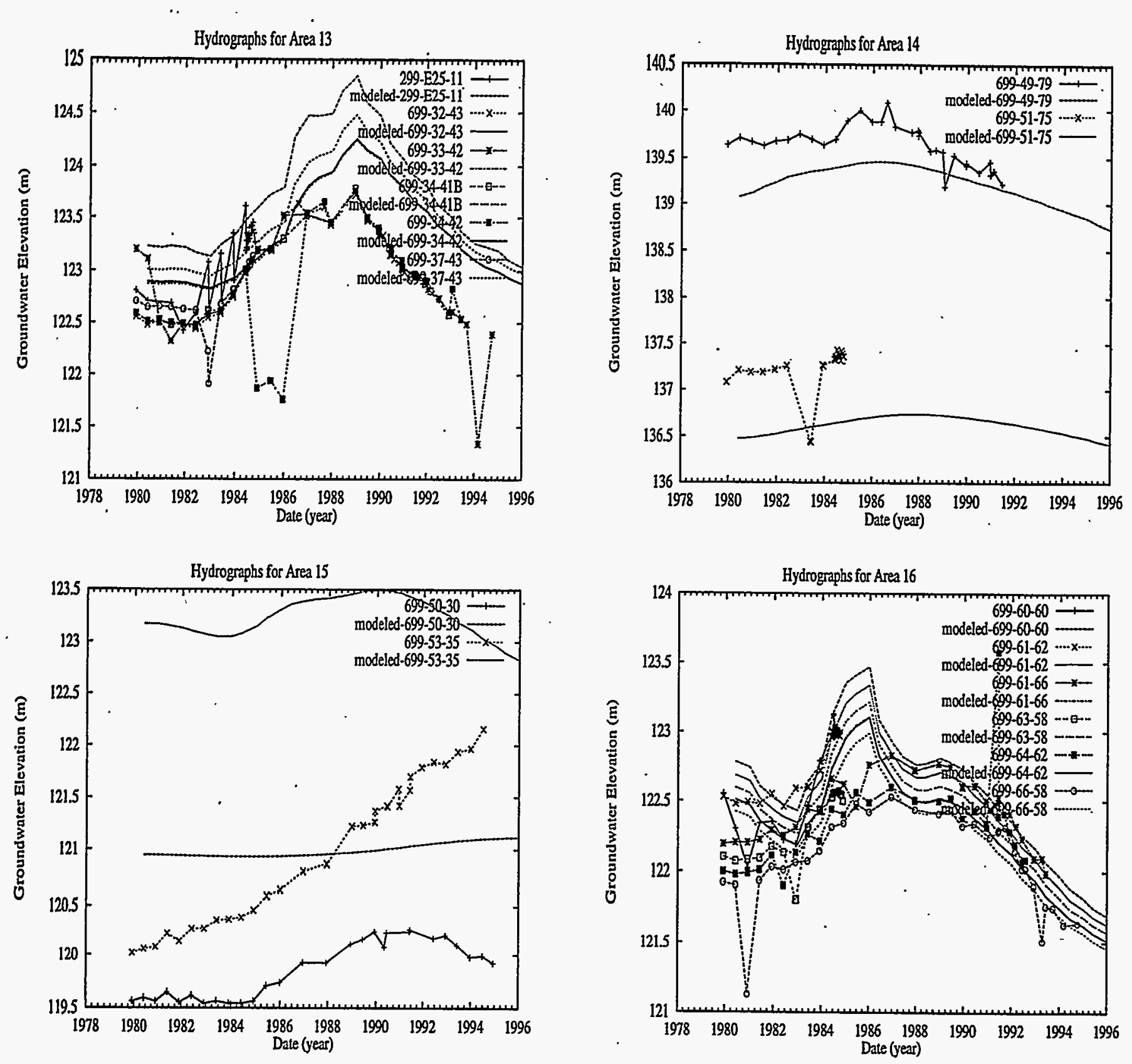

Figure 4.13. Hydrographs for Selected Wells and Model Nodes in Areas 13,14, 15, 16 from 1979 to 1996 

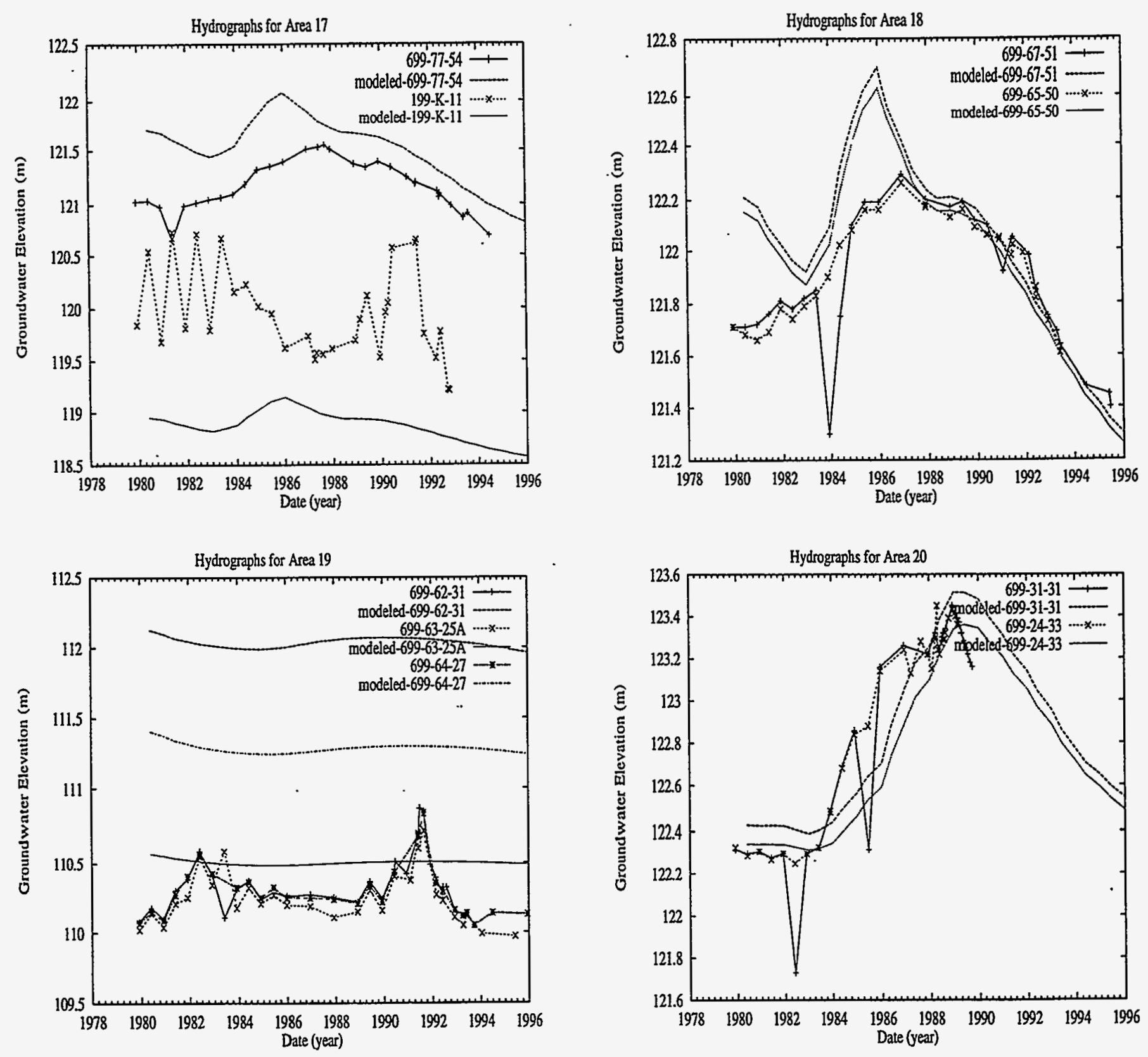

Figure 4.14. Hydrographs for Selected Wells and Model Nodes in Areas 17, 18, 19, and 20 from 1979 to 1996 


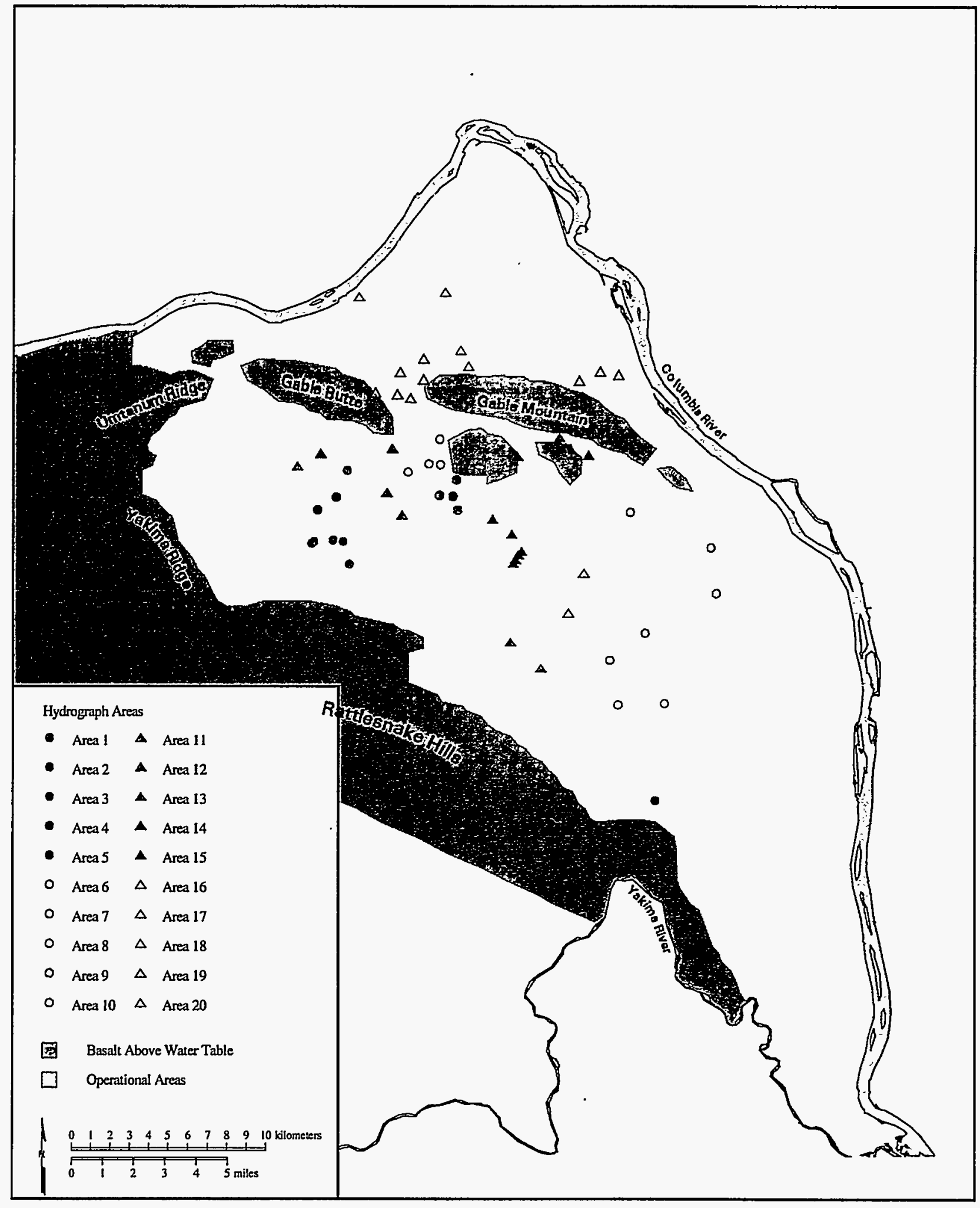

97skw025.eps December 01, 1997

Figure 4.15. Locations of Wells Shown in Hydrographs 


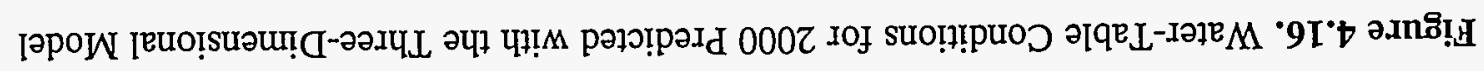

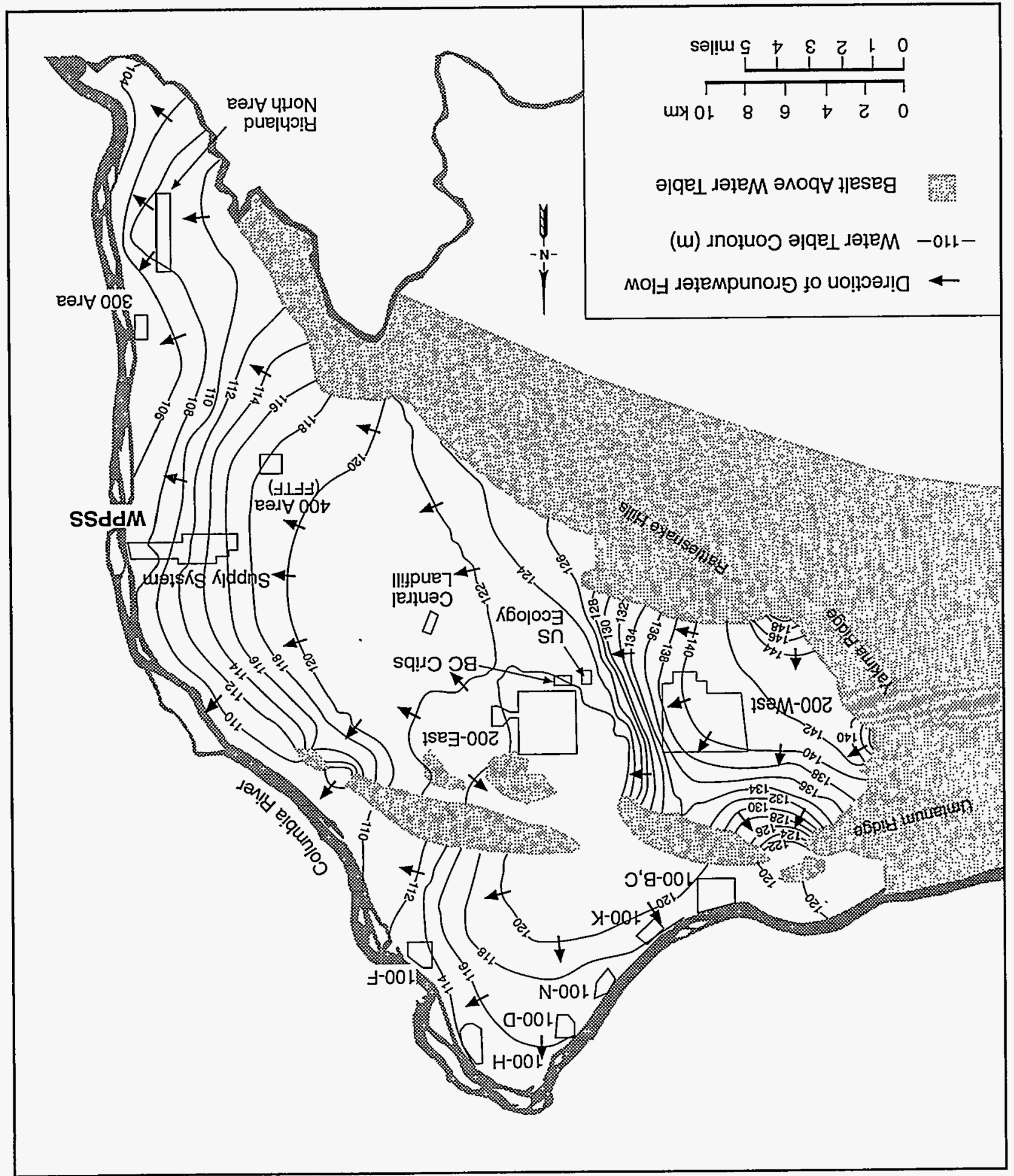




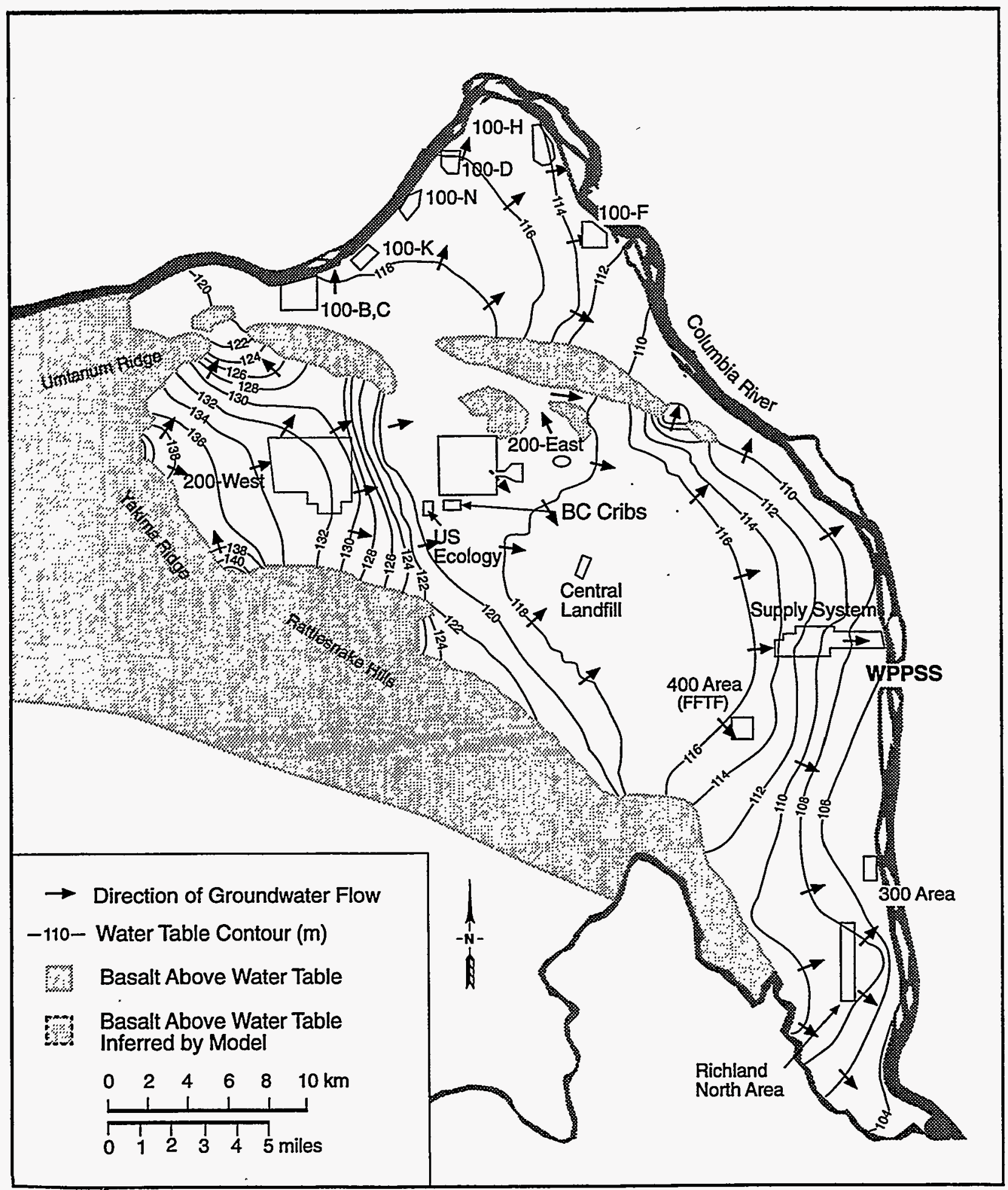

SG97090277.8

Figure 4.17. Water-Table Conditions for 2100 Predicted with the Three-Dimensional.Model 


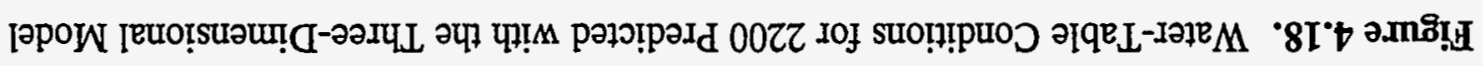

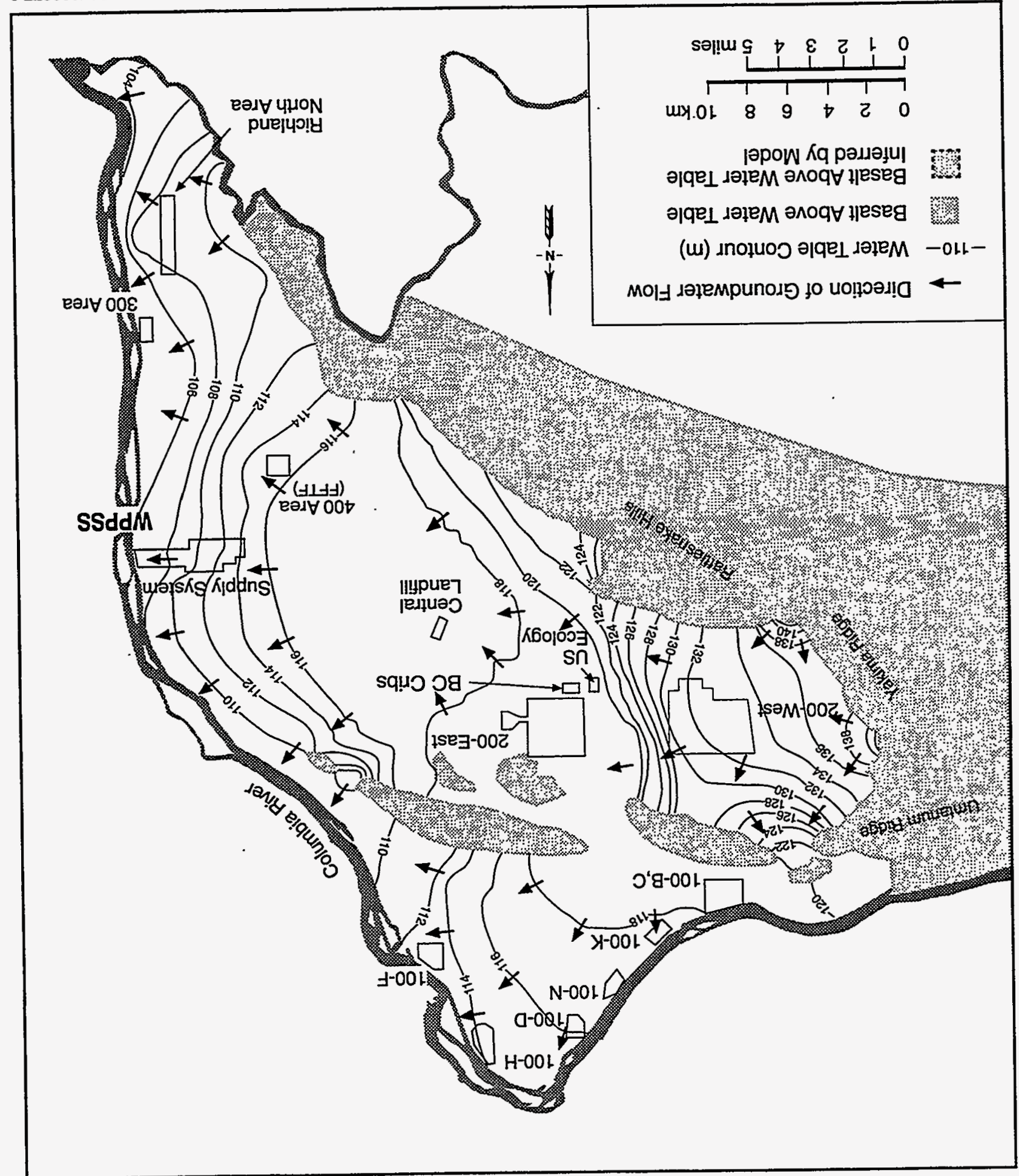




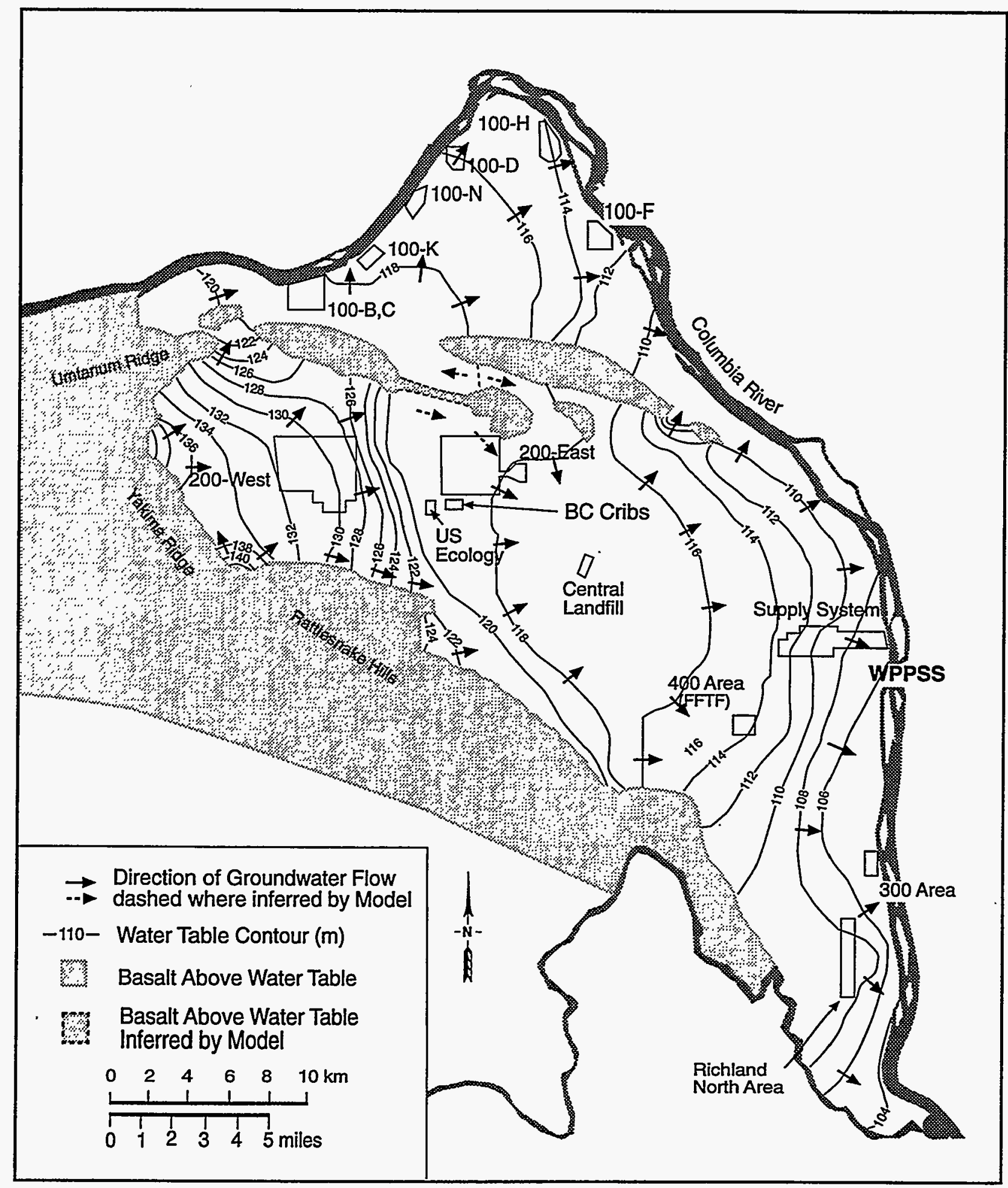

SG97090277.10

Figure 4.19. Water-Table Conditions for 2350 Predicted with the Three-Dimensional Model 

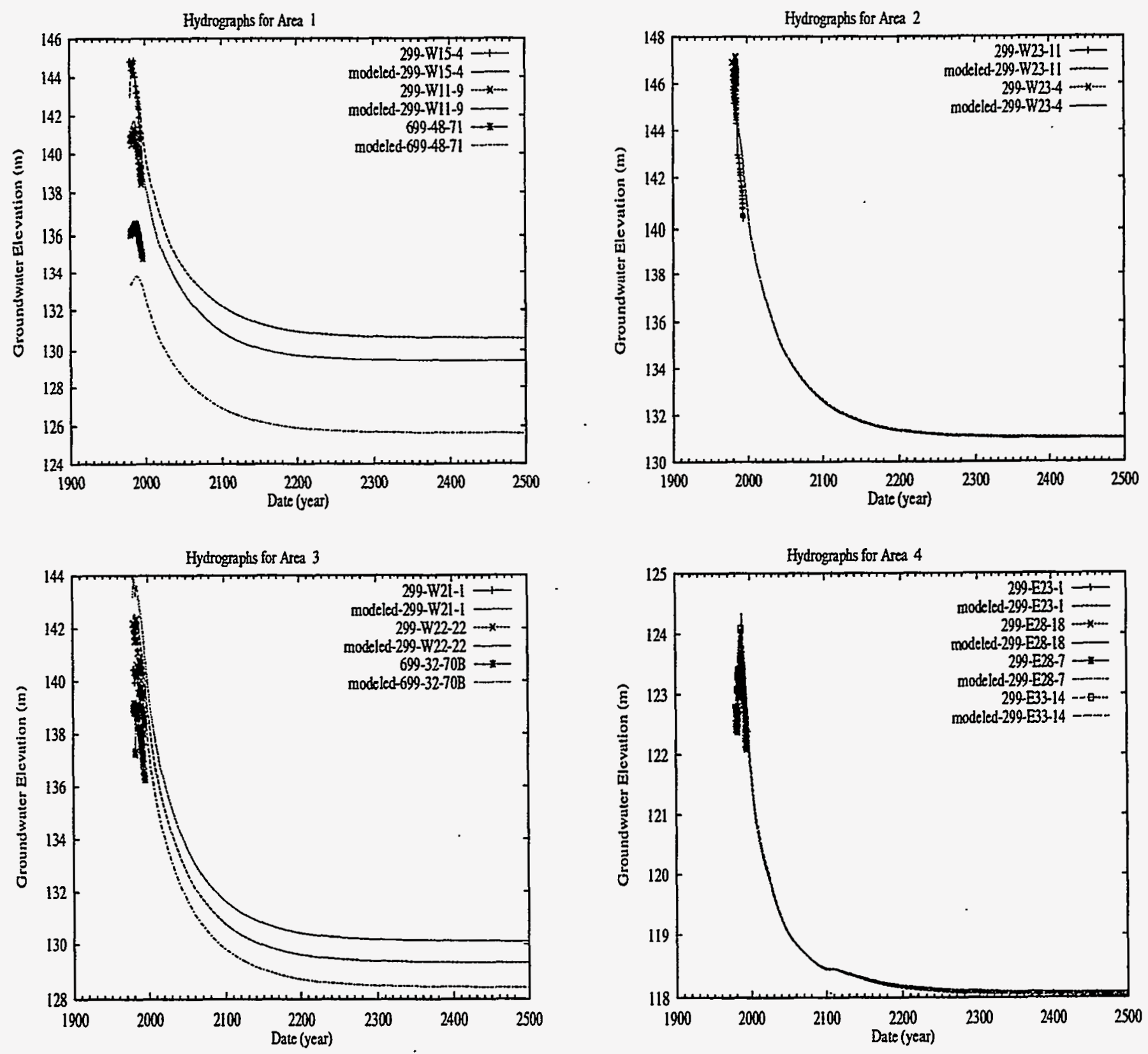

Figure 4.20. Hydrographs for Selected Wells and Model Nodes in Areas 1, 2, 3, and 4 from 1996 to 2500 

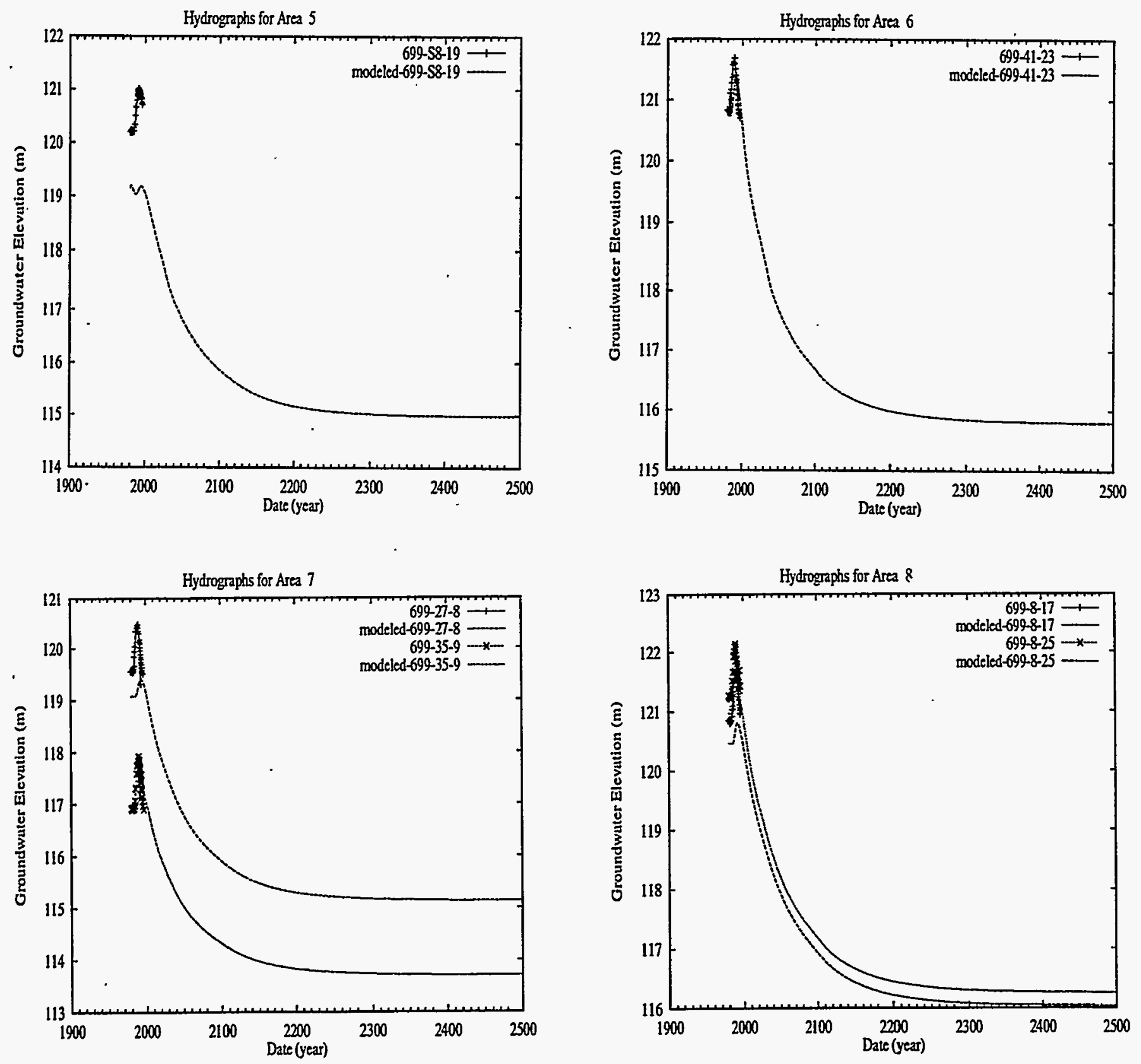

Figure 4.21. Hydrographs for Selected Wells and Model Nodes in Areas 5, 6, 7, and 8 from 1996 to 2500 

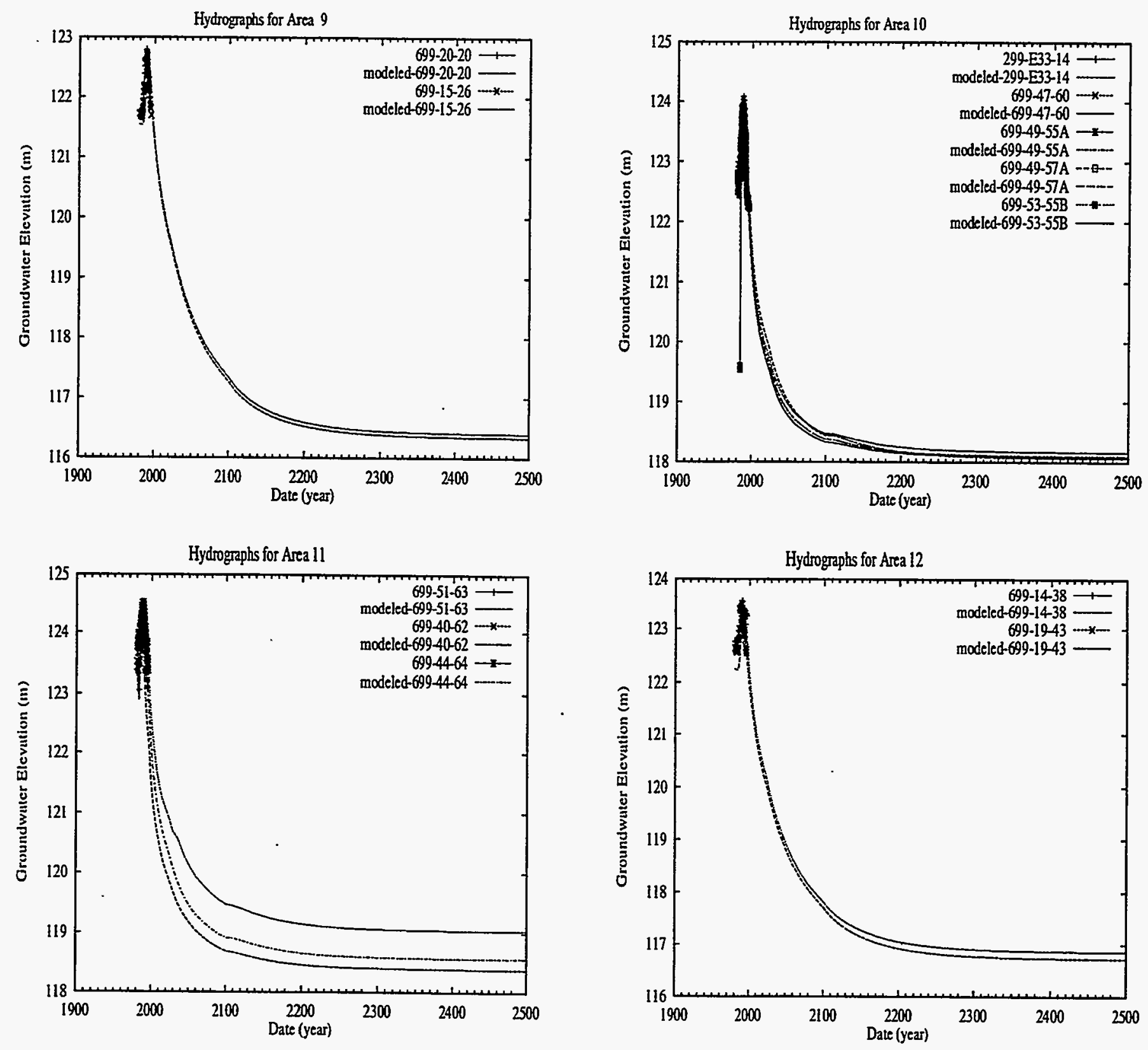

Figure 4.22. Hydrographs for Selected Wells and Model Nodes in Areas 9, 10, 11, and 12 from 1996 to 2500 

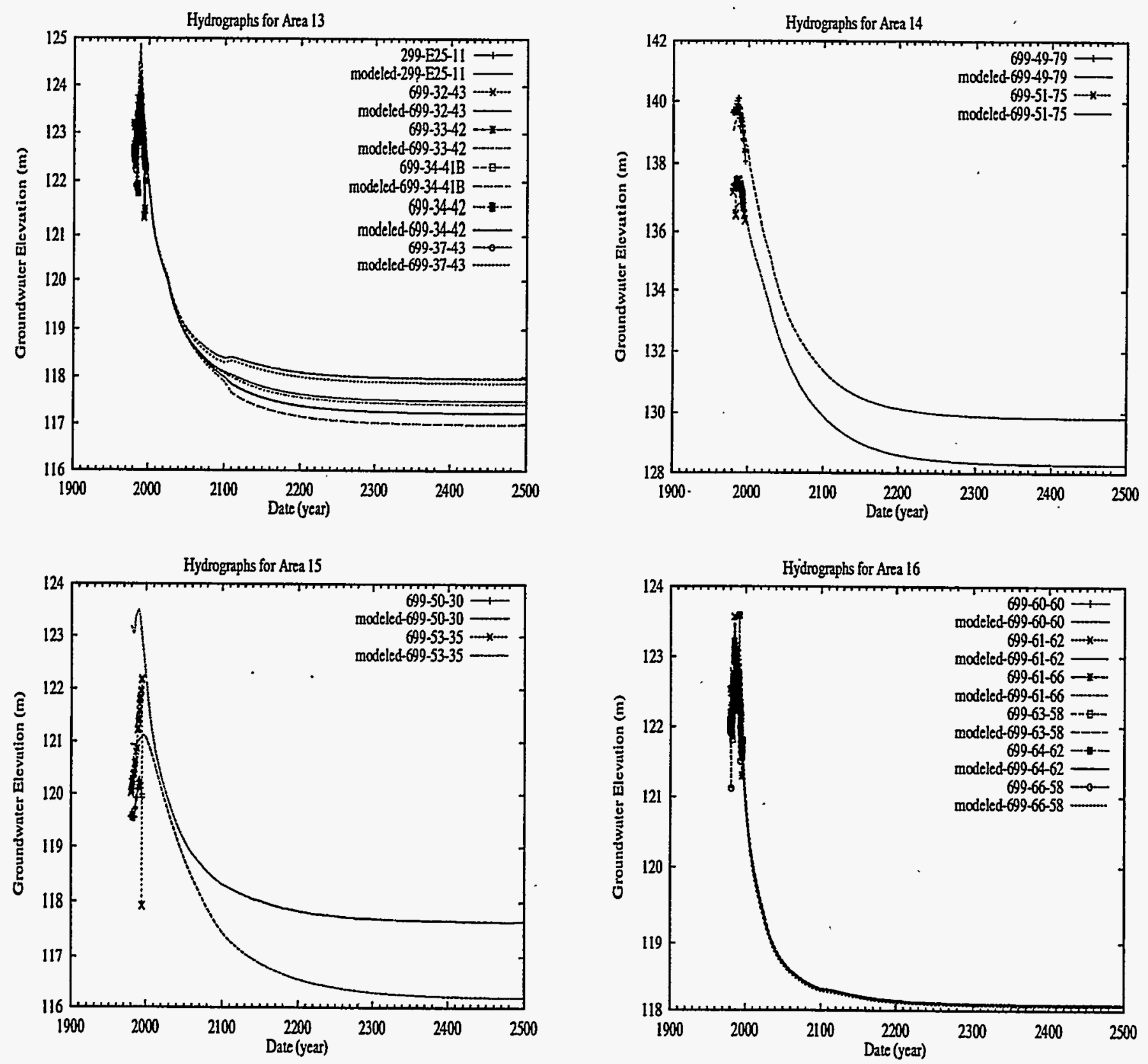

Figure 4.23. Hydrographs for Selected Wells and Model Nodes in Areas 13, 14, 15; and 16 from 1996 to 2500 

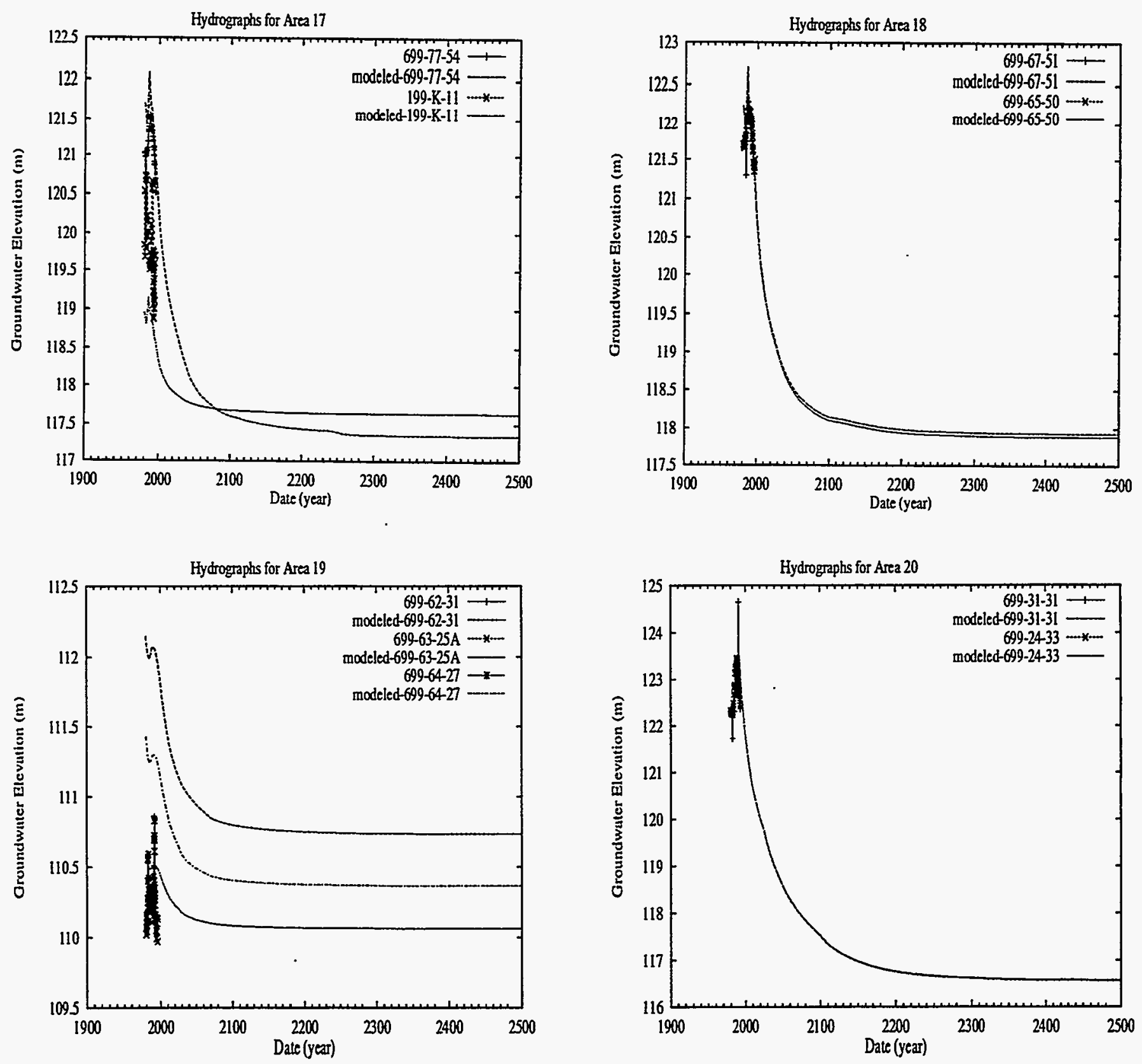

Figure 4.24. Hydrographs for Selected Wells and Model Nodes in Areas 17, 18, 19, and 20 from 1996 to 2500 


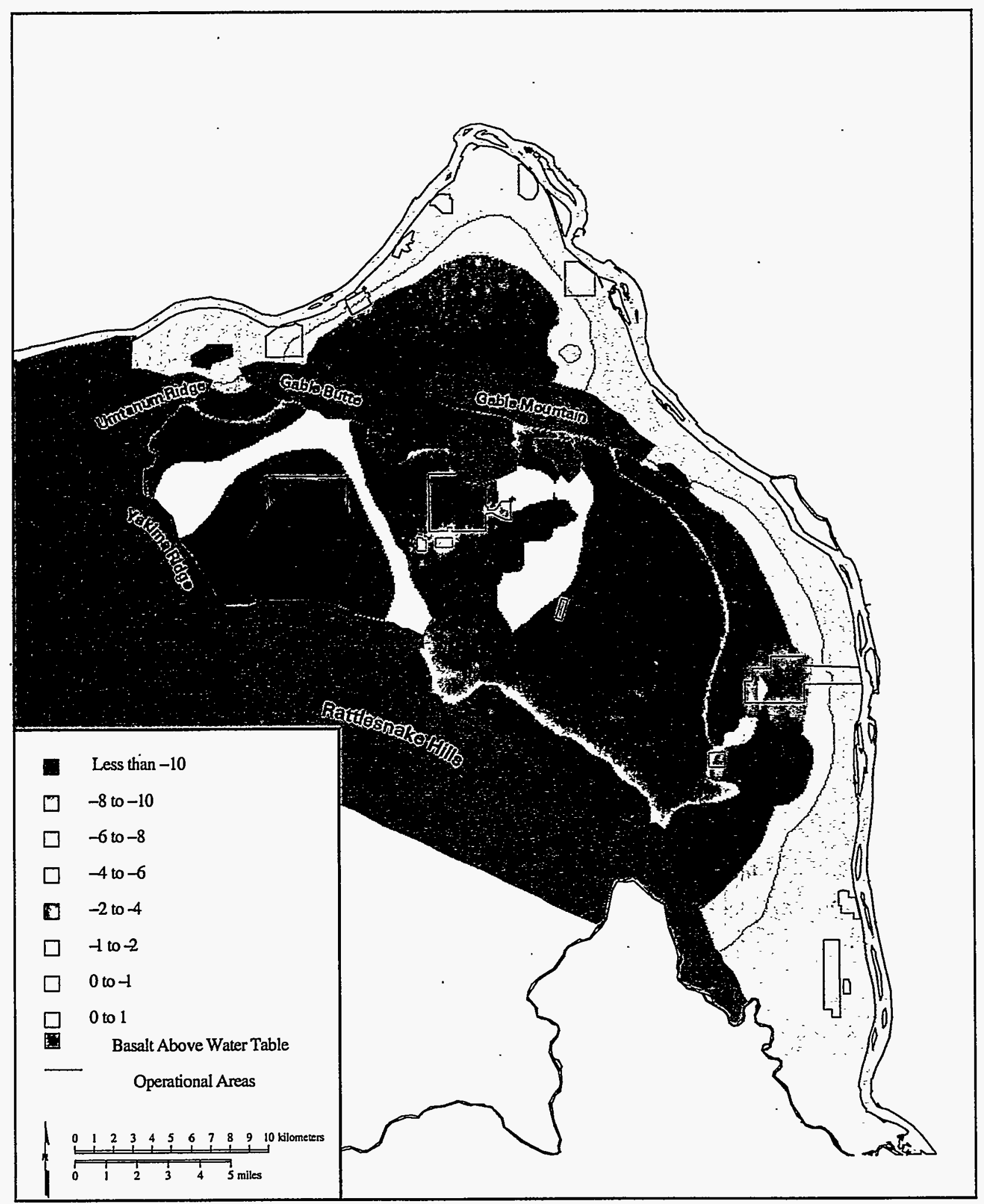

97sku028.eps December 29, 1997

Figure 4.25. Difference Between Hanford Water-Table Conditions Predicted for 2350 and 1996 


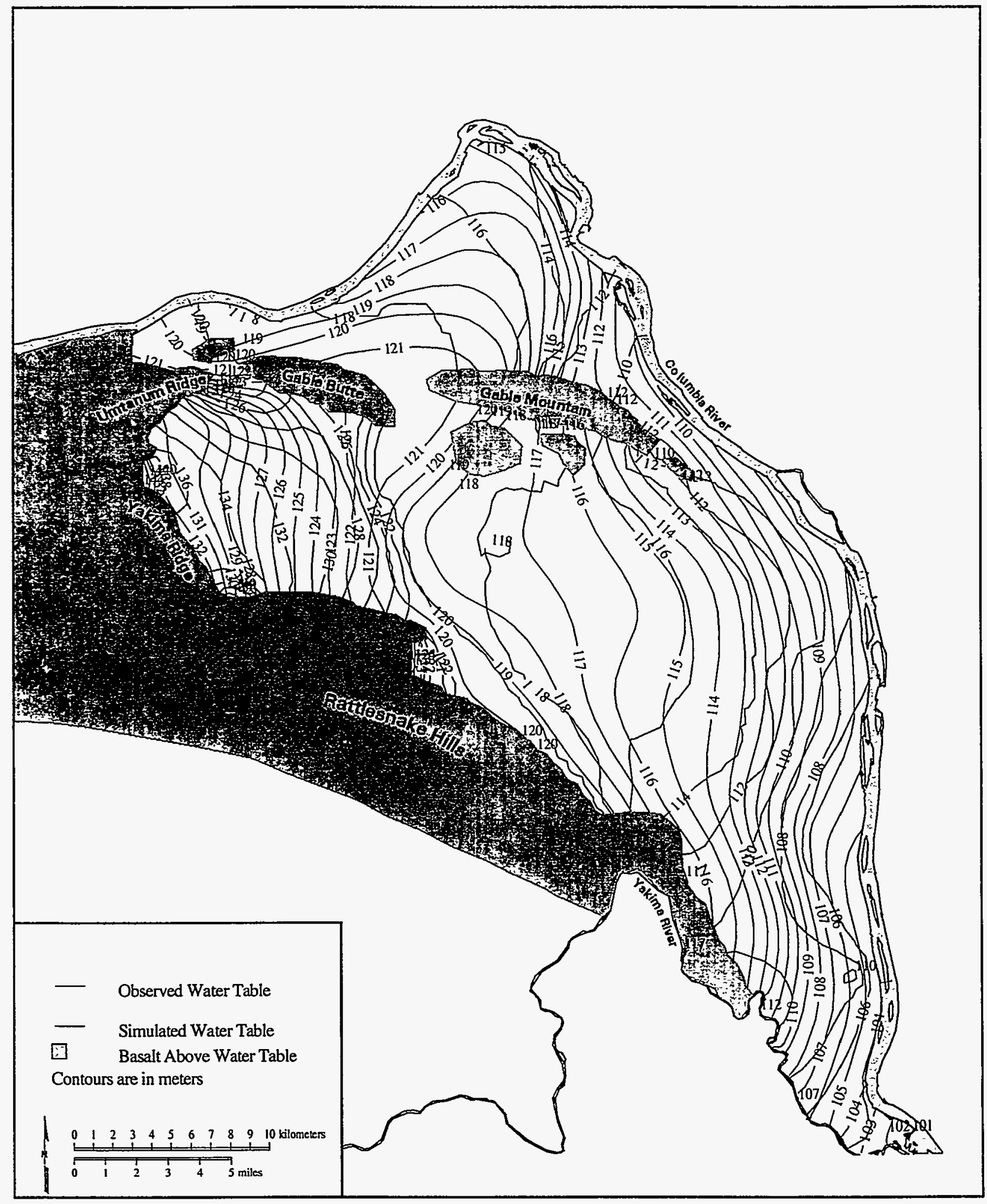

97skw029.eps Decemiber 01, 1997

Figure 4.26. Comparison of Hanford Water-Table Conditions Predicted for 2350 and Estimated Hanford Water-Table Conditions in 1944 


\subsection{Site-Wide Transport Modeling}

Transport simulations were developed to investigate contaminant mass transport issues, evaluate the future movement of contaminant plumes, and identify and quantify potential groundwater quality problems that could affect on-site and off-site use of groundwater. Monitoring of groundwater across the Hanford Site has characterized a number of radioactive contaminant plumes that emanate from various operational areas at the site, including large plumes of tritium and iodine-129 and smaller plumes of strontium- 90 , technetium-99, plutonium, uranium, cesium-137, and cobalt-60.

The focus of this analysis was to examine the transport of those radionuclides with the potential for near-term mobility and future risk. Therefore, this analysis included an evaluation of tritium, iodine-129, technetium-99, uranium, and strontium-90. Because of the strong tendency of plutonium, cesium-137, and cobalt- 60 to be sorbed on sediments within Hanford groundwater, the long-term transport of those radionuclides was not considered.

The following section describes the results derived from applying the three-dimensional transport model to existing site-wide plumes of tritium, iodine-129, technetium-99, uranium, and strontium-90.

\subsection{Transport Finite-Element Grid}

The finite-element grid used to simulate three-dimensional flow conditions in the unconfined aquifer was refined in the 200-Area plateau to add horizontal and vertical discretization of the hydrogeologic units. This was done to 1) provide adequate resolution to represent the areal variations of contaminant concentrations used as initial conditions, 2) more accurately represent flow paths, 3) minimize numerical dispersion in the transport calculations, and 4) allow for appropriate specification of initial vertical contaminant distributions (initial conditions). Because the tritium plume has the greatest areal extent of all plumes considered in the analysis, the grid refinement was primarily based on the examination of issues related to resolving the areal distribution and subsequent transport of the current tritium plume.

The finite-element grid used for transport calculations of all existing plumes (Figure 5.1) was primarily refined in the central area of the Hanford Site in the vicinity of the 200-Area plateau. In this area, each $750 \mathrm{~m}$ grid was subdivided into four grid spaces so that the final grid resolution was $375 \mathrm{~m}$ on a side. 
Within all areas of the grid, additional vertical discretization was added to minimize numerical dispersion in the vertical direction and to facilitate the assignment of initial concentrations of all the existing plumes to the uppermost computational layers of the model. The general approach was to subdivide the principal hydrologic units found at the water table (Unit 1 and Unit 5) into multiple 8-m-thick layers. A maximum of five layers was used to represent each unit. The Upper Ringold unit (Unit 4) was subdivided into two layers to provide for the isolating capabilities of this important mud unit. The original hydrogeologic layering used to represent all other units remained unchanged.

The initial concentrations of all the existing plumes were assigned to the uppermost computational layers of the model. This was done to approximate the current understanding that the bulk of contamination is found in the uppermost part of the aquifer (Eddy et al. 1978). At all locations where a contaminant plume exists, the initial conditions were applied to all nodes found within $25 \mathrm{~m}$ of the top of the aquifer (i.e., initial water-table conditions). In some areas, the aquifer is thinner than $25 \mathrm{~m}$, so the initial conditions were applied through the entire thickness of the aquifer. In finite-element solutions, nodes are involved in more than one element, resulting in the effective depth of contaminant being about $28 \mathrm{~m}$.

Results of both the combined horizontal and vertical refinement for the transport simulations yielded a final transport finite-element grid with a surface grid of 3108 nodes and 2991 elements and a total grid of 23,668 nodes and 23,128 elements.

\subsection{Transport Analysis of the Tritium Plume}

Tritium was present in many Hanford Site waste streams discharged to the soil and is the most mobile and most widely distributed radionuclide on the site. As a result, the contaminant plumes from tritium reflect the maximum extent of contamination in the groundwater at the Hanford Site.

In 1996 , tritium concentrations were greater than the interim DWS $(20,000 \mathrm{pCi} / \mathrm{L})$ in nearly all the operational areas, including parts of the 100-K, 100-N, 100-D, 100-F, 200-West, 200-East, 400, and 600 Areas (Hartman and Dresel 1997). The highest concentrations of tritium were found in wells near waste discharge cribs from the PUREX plant, exceeding Derived Concentration Guidelines $(2,000,000 \mathrm{pCi} / \mathrm{L})$ in one well. The plume from the 200-East Area has migrated eastward into the 600 and 400 Areas and to the Columbia River over a broad area extending from the Old Hanford townsite to the 300 Area. Maximum concentrations of tritium between 150,000 and $180,000 \mathrm{pCi} / \mathrm{L}$ can be found in the vicinity of the Old 
Hanford townsite. The plume has also migrated northwest through the gap between Gable Mountain and Gable Butte. In 1996, maximum concentrations of tritium in the vicinity of the gap ranged from 27,000 to $71,000 \mathrm{pCi} / \mathrm{L}$ in a few wells.

In the 200-West Area, tritium plumes originate in the vicinity of $T$ plant, the SX Tank Farm, the REDOX plant, and associated storage and disposal facilities. Near $T$ plant, maximum tritium concentrations were $120,000 \mathrm{pCi} / \mathrm{L}$ in one well. In the vicinity of the REDOX facilities, tritium concentrations reached a maximum of $1,100,000 \mathrm{pCi} / \mathrm{L}$ in one well. The larger of the two plumes originating from the REDOX plant area has been slowly migrating eastward toward the 200-East Area and has reached the area of the commercial low-level radioactive waste disposal facility operated by US Ecology.

The overall approach in predicting future transport of tritium was to model the current distribution of tritium forward in time until the entire tritium plume is discharged into the Columbia River or has decayed away. To establish some confidence in the general validity of the calculations, transport calculations were initiated in 1979 and continued through 1996, using historical records of tritium discharges to the land surface at various facilities on site. These results were then compared to conditions measured in 1996 . The average annual discharges used in these calculations are provided in Table A.1 in Appendix A. Beyond 1996 , the only tritium discharges simulated were currently projected discharges at the SALDS in the 200West Area, which are expected to continue through the year 2025. Current records of discharges and future projected discharges used in the tritium transport calculations are provided in Table A.2 of Appendix A. A separate detailed analysis of the impact of tritium discharges at the SALDS made with the current threedimensional transport model has recently been completed and documented in a report by Barnett et al. (1997).

\subsubsection{Initial Conditions and Transport Parameters}

Initial conditions for the tritium plume transport simulation were defined based on the extent of the tritium plume as interpreted in 1979. A surface representing the distribution of tritium in wells monitoring the upper portion of the unconfined aquifer at the Hanford Site during 1979 was prepared with data available in the Hanford Environmental Information System (HEIS). Tritium results for groundwater samples from wells completed in the upper portion of the Hanford Site unconfined aquifer were reviewed, and suspect (off-trend) data were removed. $\log$ (base 10) values of mean tritium concentrations for selected wells were interpolated to a regular grid, using the minimum tension interpolation (gridding) 
algorithm supplied with EarthVision. ${ }^{\otimes}$ Contours of the logged values from the gridded surface were compared to contours presented by Eddy and Wilbur (1980).

In areas where the contours generated from the interpolated surface differed from the contours presented by Eddy and Wilbur (1980), groundwater data were reviewed to determine which surface better represented tritium concentrations in the unconfined aquifer during 1979 . Where the spatial distribution of groundwater data was not sufficient to control interpolation, additional control was added using a graphic editor in EarthVision, ${ }^{\circledR}$ after which the surface was reinterpolated. When a satisfactory fit of the interpolated surface to the observed tritium concentrations was achieved that was also consistent with the conceptual understanding of the tritium distribution in the unconfined aquifer, the surface was converted from logged to actual values. This new surface, representing the distribution of tritium concentrations, was then checked against the observed concentrations of tritium in groundwater and the conceptual understanding of tritium distribution in the Hanford Site unconfined aquifer during 1979. The final distribution of tritium in the unconfined aquifer for 1979 (Figure 5.2) was used to represent the initial tritium concentrations in the three-dimensional transport model simulations.

As indicated earlier, the initial concentrations were assigned only to the uppermost layers of the model to approximate the current understanding that the bulk of contamination is found in the uppermost portion of the aquifer. At all locations where the tritium plume exists, initial conditions were applied to all nodes found within $25 \mathrm{~m}$ of the top of the aquifer (i.e., initial water-table conditions). In some areas, the aquifer is thinner than $25 \mathrm{~m}$ (e.g., near basalt outcrops), so the initial conditions were applied through the entire thickness of the aquifer.

\subsubsection{Results and Discussion}

Results of tritium transport for the period from 1979 through 1996 (Figures 5.2, 5.3, and 5.4) showed the same overall trends of contaminant migration as reported by the HGWP. Model results showed that the tritium plumes originating from the 200 -East and 200 -West areas slowly migrate laterally in a general easterly direction and discharge to the Columbia River along a broad area between the Old Hanford townsite and north of the 300 Area. Maximum concentrations of tritium in the 600 Area (downgradient of the 200-East Area) decline from over the 2 million pCi/L level in 1979 to above $200,000 \mathrm{pCi} / \mathrm{L}$ in 1996 . In 1996 , tritium levels in wells within the maximum area of concentration ranged from 150,000 to 180,000 $\mathrm{pCi} / \mathrm{L}$. 
Within the 200-East Area, maximum tritium concentrations, which were initially at several hundred thousand $\mathrm{pCi} / \mathrm{L}$ in 1979 , declined steadily until 1985 , when discharges originating from PUREX plant operations startup caused the tritium concentration to rise rapidly above the 5 million $\mathrm{pCi} / \mathrm{L}$ level. With the cessation of these discharges in 1988 , simulated tritium levels declined to the several hundred thousand pCi/L level by 1996 . These simulated levels of tritium are consistent with levels measured in wells within the same area, which ranged from about 200,000 to 1 million $\mathrm{pCi} / \mathrm{L}$.

In the 200-West Area, initial maximum tritium concentrations exceeding 5 million $\mathrm{pCi} / \mathrm{L}$ were simulated to decline steadily to several hundred thousand $\mathrm{pCi} / \mathrm{L}$ by 1996 . These simulated levels are, in general, consistent with tritium levels currently measured in wells in the same area.

A comparison of simulated (Figure 5.4) and observed (Figure 5.5) distributions of tritium for 1996 conditions show a few differences worth noting:

- Simulated levels of tritium predicted at the water table show a higher level of dispersion than inferred from the interpreted concentrations. These differences could be attributable to the assumption made about distributing the initial conditions in the model over the first $25 \mathrm{~m}$ of the aquifer thickness. This assumption may or may not be appropriate in the areas of past contamination. These differences may also reflect the fact that the model results illustrate the maximum level of tritium forecasted at the water table; most wells used to sample for tritium are screened over aquifer thicknesses ranging from 5 to $20 \mathrm{~m}$. If values of tritium predicted at depth in the model were averaged to reflect measured well concentrations, they might compare more favorably with the areal extent of measured concentrations. More analyses at individual wells would be needed before this type of comparison could be made.

- Levels of tritium forecasted at the water table in areas downgradient of the 200-East Area are, in general, much higher than inferred by measurements in wells. Maximum measured well concentrations are on the order of $180,000 \mathrm{pCi} / \mathrm{L}$ in the upper part of aquifer near the Old Hanford townsite. Predicted values at the water table in this same area reached a level of just over $500,000 \mathrm{pCi} / \mathrm{L}$. As in the previous point, if values of tritium predicted at depth in the model were averaged to reflect measured well concentrations, they might compare more favorably with the levels of measured concentrations. These differences could be attributable to the assumption made about distributing the initial conditions in the model over the first $25 \mathrm{~m}$ of the aquifer thickness. This 
assumption may or may not be appropriate in the areas of past contamination and may be accounting for a higher level of activity in the aquifer at the start of the transport simulation.

- The extent of tritium plume migration south of the 300 Area along the Columbia River was not predicted in the transport model. This discrepancy may be attributable to the assumption that an average stage in the Columbia River is a suitable assumption when examining the long-term behavior of the tritium plume from the 200-Area plateau. In reality, the actual stage in the Columbia River fluctuates 2 to $4 \mathrm{~m}$ on a daily basis. Over the long term, these daily fluctuations and the resulting groundwater surface interaction may influence the behavior of the tritium plume and cause the plume to slowly migrate downstream and subparallel to the river. Long-term transport simulations which consider or approximate the actual fluctuations in the Columbia River would be needed to thoroughly investigate the effect of these transient river phenomena.

Model results from 1996 through 2100 (Figures 5.6, 5.7, 5.8, and 5.9) show that the current tritium plumes will continue to slowly migrate laterally from source locations in the 200 Areas to the Columbia River north and east of the 200-Area plateau. Concentration levels of the simulated plumes in nearly all areas will decline by processes of radioactive decay and plume dispersion as they migrate. The only source of future tritium that was simulated was assumed to originate from projected discharges of tritium at the SALDS from 1996 through 2026.

In the 200-West Area, maximum tritium levels exceeding about 3 million $\mathrm{pCi} / \mathrm{L}$ simulated at the SALDS decline to 1 million $\mathrm{pCi} / \mathrm{L}$ in $2000,80,000 \mathrm{pCi} / \mathrm{L}$ in 2020 , several thousand $\mathrm{pCi} / \mathrm{L}$ in 2050 , and below detection by 2100 . In the 200-East Area, maximum tritium levels exceeding several hundred thousand $\mathrm{pCi} / \mathrm{L}$ simulated near the PUREX plant decline to tens of thousand $\mathrm{pCi} / \mathrm{L}$ in 2000 , several thousand $\mathrm{pCi} / \mathrm{L}$ in 2020 , below $1000 \mathrm{pCi} / \mathrm{L}$ in 2050 , and below detection by 2100 . In the 600 Area (downgradient of the 200-Area plateau), maximum tritium levels exceeding several hundred thousand $\dot{\mathrm{p} C i} / \mathrm{L}$ simulated near the Old Hanford townsite decline to just above $200,000 \mathrm{pCi} / \mathrm{L}$ in 2000 , below $200,000 \mathrm{pCi} / \mathrm{L}$ in 2020 , below $80,000 \mathrm{pCi} / \mathrm{L}$ in 2050 , below 2000 by 2100 , and below $500 \mathrm{pCi} / \mathrm{L}$ by 2150 . Maximum tritium concentrations discharge from the unconfined aquifer to the Columbia River near the Old Hanford townsite east of the 200-East Area. Groundwater containing tritium concentrations exceeding $20,000 \mathrm{pCi} / \mathrm{L}$ are predicted to discharge at this location for 50 to 60 years. Groundwater containing tritium concentrations exceeding $2,000 \mathrm{pCi} / \mathrm{L}$ are predicted to discharge at this location over a period of 80 to 90 years. 
Tritium contamination found in the area north of Gable Mountain and Gable Butte slowly migrates toward the Columbia River. The combination of radioactive decay, dispersion during transport, and discharge of groundwater containing tritium in the 100 Areas causes tritium levels in this area to decline steadily from 1996 levels to below detection $(500 \mathrm{pCi} / \mathrm{L})$ by 2070 .

\subsection{Transport Analysis of Iodine-129 Plume}

According to Hartman and Dresel (1997), the main on-site contributor of iodine-129 to groundwater is liquid discharges to cribs located near fuel-processing facilities in the 200 Areas. Extensive plumes of iodine-129 exceeding the interim DWS $(1 \mathrm{mg} / \mathrm{L})$ originate in the 200 Areas and in downgradient portions of the 600 Areas. The presence of iodine-129 is of concern because of its low interim DWS $(1 \mathrm{pCi} / \mathrm{L})$, its long-term release from fuel reprocessing facilities, and its long half-life (about 16 million years).

In the 200-East Area, wells exceed the interim DWS of $1 \mathrm{pCi} / \mathrm{L}$ along the eastern edge and the northern half of the area. Peak values exceeding $10 \mathrm{pCi} / \mathrm{L}$ are found in several wells located near the PUREX facility. The plume originating in the 200-East Area has migrated eastward as much as $10 \mathrm{~km}$ toward the Columbia River. In this area, maximum concentrations of iodine- 129 between 6 and $9 \mathrm{pCi} / \mathrm{L}$ can be found in two wells.

In the 200-West Area, plumes of iodine-129 originate from liquid discharge points near $T$ plant, $U$ Plant, and the REDOX plant. Wells in both of these areas contain iodine-129 levels that exceed the interim DWS ( $1 \mathrm{pCi} / \mathrm{L}$ ). The highest concentrations of iodine- 129 are found in wells near waste discharge cribs in the vicinity of the REDOX plant, exceeding $80 \mathrm{pCi} / \mathrm{L}$ in one well and $20 \mathrm{pCi} / \mathrm{L}$ in other wells. The plume from the 200-West Area has migrated slowly eastward toward the 200-East Area.

\subsubsection{Assumptions and Initial Conditions}

The approach to simulating future transport of the iodine- 129 plume was to start the simulation with initial conditions from 1996 and calculate future transport of iodine-129 based on the three-dimensional transient-flow field discussed in Section 4.3.2. For the purpose of this analysis, no further contributions of iodine-129 were considered. Future releases of iodine- 129 are being estimated and analyzed as part of the Hanford Site Composite Analysis. 
Initial conditions for the iodine-129 plume were defined based on the extent of the iodine-129 plume in 1996. Because no additional discharges of iodine-129 were assumed to occur, the area defined by the 1996 plume is sufficient to represent the maximum extent of that plume. The initial conditions for iodine- 129 were generated in the same manner as initial conditions for tritium (i.e., the 1996 plume was used as an initial condition). The same grid defined for the tritium plume (Figure 5.1) was used for the iodine-129 plume. The simulation was started with 1996 iodine-129 concentrations as initial conditions (Figure 5.10). The 1996 concentrations were used because the iodine-129 data for 1979 were not available.

\subsubsection{Results and Discussion}

Transport model results for iodine-129 from 1996 through 2300, shown in Figures 5.11. 5.12, 5.13, and 5.14, demonstrate that current iodine-129 plumes will continue to slowly migrate laterally from source locations in the 200 Areas to the Columbia River north and east of the 200-Area plateau. Concentration levels of the simulated plumes in nearly all areas decline by the processes of plume dispersion and dilution related to infiltration.

In the 200-West Area, maximum iodine- 129 levels exceeding $50 \mathrm{pCi} / \mathrm{L}$ near the REDOX facilities decline to less than $50 \mathrm{pCi} / \mathrm{L}$ in 2000 , less than $30 \mathrm{pCi} / \mathrm{L}$ in 2031 , about $20 \mathrm{pCi} / \mathrm{L}$ in 2050 , less than $10 \mathrm{pCi} / \mathrm{L}$ in 2100 , and less than $5 \mathrm{pCi} / \mathrm{L}$ by 2400 . In the 200 -East Area, maximum iodine- 129 levels exceeding $10 \mathrm{pCi} / \mathrm{L}$, simulated near the PUREX plant, decline to less than $5 \mathrm{pCi} / \mathrm{L}$ by 2031 and less than 1 $\mathrm{pCi} / \mathrm{L}$ by 2100 . In the 600 Area (downgradient of the 200-Area plateau), maximum iodine levels exceeding $5 \mathrm{pCi} / \mathrm{L}$ simulated between the 200-East Area and the Old Hanford townsite decline to less than $5 \mathrm{pCi} / \mathrm{L}$ in 2200 and below $1 \mathrm{pCi} / \mathrm{L}$ in 2400 . Maximum iodine- 129 concentrations discharge from the unconfined aquifer to the Columbia River near the Old Hanford townsite east of the 200-East Area. Groundwater containing iodine- 129 concentrations exceeding $1 \mathrm{pCi} / \mathrm{L}$ are predicted to discharge at this location over a period of about 570 years, from about 2030 to 2600 .

Iodine-129 contamination found in the area north of Gable Mountain and Gable Butte slowly migrates toward the Columbia River. The combination of radioactive decay and dispersion during transport causes iodine-129 levels in this area to decline steadily from 1996 levels (less than $2 \mathrm{pCi} / \mathrm{L}$ ) to less than $0.1 \mathrm{pCi} / \mathrm{L}$ by 2700 . 


\subsection{Transport Analysis of Technetium-99 Plume}

According to Hartman and Dresel (1997), technetium-99 is a highly mobile radionuclide of concern that has been present in a number of waste streams associated with fuel reprocessing at the Hanford Site. Technetium- 99 has been detected at levels exceeding the $\mathrm{DWS}$ of $900 \mathrm{pCi} / \mathrm{L}$ in a number of areas on the site. In the 200-West Area, technetium-99 exceeded the DWS in several areas. Highest concentrations are found in the plume originating from the U Plant area where technetium-99 levels exceed $9,000 \mathrm{pCi} / \mathrm{L}$ in a number of wells and $20,000 \mathrm{pCi} / \mathrm{L}$ in one well. Technetium- 99 concentration levels exceed $900 \mathrm{pCi} / \mathrm{L}$ in wells located within a plume originating from the northern 200-East Area that is migrating through the gap between Gable Mountain and Gable Butte. In the 100-H Area, technetium-99 concentrations exceed 900 $\mathrm{pCi} / \mathrm{L}$ in wells downgradient of the $183-\mathrm{H}$ solar evaporation basins, where fuel-processing wastes have leaked into the ground.

\subsubsection{Assumptions and Initial Conditions}

The approach to simulating future transport of the technetium-99 plume was the same as that used for the iodine-129 plume. The simulation was initiated using the 1996 conditions, and future transport of technetium-99 was based on the three-dimensional transient-flow field discussed in Section 4.3.2. For purposes of this analysis, no further contributions of technetium- 99 were considered. As in the case of iodine-129, future releases of technetium-99 are being estimated and analyzed as part of the Hanford Site Composite Analysis.

Initial conditions used for the technetium-99 plume were defined based on the extent of the technetium-99 plume in 1996. Because no additional discharges of technetium-99 were assumed to occur, the area defined by the 1996 plume is sufficient to represent the maximum extent of that plume. The initial conditions for technetium- 99 were generated in the same manner as initial conditions for tritium (i.e., the 1996 plume was used as an initial condition). It was found that the same three-dimensional grid defined for the tritium plume originating from the 200 areas (Figure 5.1) could be used for the technetium-99 plume. The 1996 technetium- 99 concentrations used as initial conditions are presented in Figure 5.15. 


\subsubsection{Results and Discussion}

Transport model results for technetium-99 from 1996 through 2300 shown in Figures 5.16, 5.17, 5.18, and 5.19 illustrate how the plumes in the 200-West Area decline to levels below regulatory concern as they migrate eastward toward the 200-East Area. The technetium-99 plume in the northern part of the 200-East Area, which is migrating northward through the gap between Gable Butte and Gable Mountain, will continue to migrate in this direction toward the Columbia River. However, concentration levels of the simulated plumes decline to below regulatory levels over a period of 100 years by the processes of plume dispersion and dilution related to infiltration.

In the 200-West Area, maximum technetium-99 levels exceeding $7000 \mathrm{pCi} / \mathrm{L}$ near the REDOX facilities decline to less than $5000 \mathrm{pCi} / \mathrm{L}$ in 2000 , less than $500 \mathrm{pCi} / \mathrm{L}$ in 2031 , and less than $90 \mathrm{pCi} / \mathrm{L}$ by 2100. In the 200-East Area, maximum technetium-99 levels exceeding $1500 \mathrm{pCi} / \mathrm{L}$, simulated north of the BY crib area, decline to less than $500 \mathrm{pCi} / \mathrm{L}$ by 2000 and less than $90 \mathrm{pCi} / \mathrm{L}$ by 2011 .

Technetium-99 contamination levels found in the area north of Gable Mountain and Gable Butte slowly migrate toward the Columbia River. The combination of dispersion and infiltration from recharge during transport causes technetium-99 levels in this area to decline steadily from 1996 levels (above. $1000 \mathrm{pCi} / \mathrm{L}$ ) to less than $90 \mathrm{pCi} / \mathrm{L}$ by 2020 .

Groundwater containing technetium-99 levels above $900 \mathrm{pCi} / \mathrm{L}$ in the 100 areas are expected to quickly migrate into the Columbia River within the next 10 years and were not specifically considered in this simulation.

\subsection{Transport Analysis of Uranium Plume}

According to Hartman and Dresel (1997), uranium releases at the Hanford Site have numerous potential sources, including discharges from fabrication, fuel reprocessing, and uranium recovery. Uranium mobility has been found to be slower than that of tritium and technetium- 99 because of its dependency on both Eh and $\mathrm{pH}$ conditions. At $\mathrm{Eh} / \mathrm{pH}$ conditions in the unconfined aquifer, $\mathrm{U}^{6+}$ is found to be the most mobile species of uranium. 
Uranium has been detected at concentrations above the maximum concentration limit proposed by EPA of $20 \mu \mathrm{g} / \mathrm{L}$ in the $100-\mathrm{H}, 100-\mathrm{F}, 200$, and 300 areas. Contamination in the $100-\mathrm{H}, 100-\mathrm{F}$, and 200-East areas has been very localized. In the 200-West Area, the most extensive contamination occurs in a plume that originates from two cribs located at the U Plant. This plume is currently migrating slowly toward the 200-East Area. Uranium concentrations in this plume exceed $1,000 \mu \mathrm{g} / \mathrm{L}$ in a number of wells, and the plume is currently being contained by a pump-and-treat system.

In the 300 Area, elevated concentrations of uranium are found downgradient of the 316-5 process trenches and moving in a southeasterly direction. An expedited response action was performed on the trenches in mid-1991 to reduce the uranium source in this area. Current levels of uranium exceed $20 \mu \mathrm{g} / \mathrm{L}$ in many wells downgradient of the trenches; uranium concentrations in a smaller number of wells exceed $100 \mu \mathrm{g} / \mathrm{L}$.

\subsubsection{Assumptions and Initial Conditions}

The overall approach for simulating future transport of the uranium plumes was to initiate the simulation from 1996 conditions as was done for the iodine-129 and technetium-99 plumes. For purposes of this analysis, no further contributions of uranium were considered. As in the case of iodine-129 and technetium-99, future releases of uranium are being estimated and analyzed as part of the Hanford Site Composite Analysis.

The initial conditions used for the uranium plume were defined based on the extent of the uranium plume in 1996 and future transport of uranium was calculated based on the three-dimensional transientflow field discussed in Section 4.3.2. Because no additional discharges of uranium will likely occur at the Hanford Site, the area defined by the 1996 plume is sufficient to represent the maximum extent of that plume. The initial conditions for uranium were generated in the same manner as initial conditions for tritium (i.e., the 1996 plume was used as an initial condition). It was found that the three-dimensional grid defined for the 200 Area tritium plume (Figure 5.1) could be used for the uranium plume. The 1996 uranium concentrations used as initial conditions are presented in Figure 5.20. 


\subsubsection{Results and Discussion}

Transport model results for uranium from 1996 through 2200, as shown in Figures 5.21, 5.22, 5.23, and 5.24, indicated that because of the process of adsorption, the current uranium plumes in the 200-Area plateau will not migrate significantly from current source locations in the 200 areas outside of the 200 Area exclusion and buffer zones. Concentration levels of the simulated plumes in the 200 areas will decline to below $20 \mu \mathrm{g} / \mathrm{L}$ over the next 50 years by the process of plume dispersion and dilution related to areal recharge.

In the 200-West Area, maximum uranium levels exceeding $400 \mu \mathrm{g} / \mathrm{L}$ near the REDOX facilities decline to less than $400 \mu \mathrm{g} / \mathrm{L}$ in 2000 , less than $300 \mu \mathrm{g} / \mathrm{L}$ in 2011 , less than $100 \mu \mathrm{g} / \mathrm{L}$ by 2100 , and less than $20 \mu \mathrm{g} / \mathrm{L}$ by the year 3000. Maximum uranium levels exceeding $50 \mu \mathrm{g} / \mathrm{L}$ simulated in the northern part of the 200 -East Area decline to less than $50 \mu \mathrm{g} / \mathrm{L}$ by 2000 , less than $20 \mu \mathrm{g} / \mathrm{L}$ by 2005 , and less than $2 \mu \mathrm{g} / \mathrm{L}$ by the year 2100 .

Groundwater containing uranium levels above $20 \mu \mathrm{g} / \mathrm{L}$ in the 100 , and 300 areas is expected to discharge into the Columbia River within the next 40 to 50 years. Consequently, these plumes were not specifically considered in this simulation.

\subsection{Transport Analysis of Strontium-90 Plume}

According to Hartman and Dresel (1997), strontium-90 has been present and may have been released in waste streams associated with fuel processing. Release of strontium- 90 by fuel-element failures during reactor operations is also suspected. Strontium- 90 is considered to be the least mobile of all radioactive constituents being considered in this analysis. However, the occurrence of strontium-90 in groundwater is of concern because of its moderately long half-life ( 28.8 years), its potential for concentrating in bone tissue, and the relatively high energy of the beta decay from its yttrium-90 radioactive decay product.

In 1996 , strontium-90 concentrations exceeded the interim DWS of $8 \mathrm{pCi} / \mathrm{L}$ in wells within the 100 and 200 Areas. Strontium- 90 concentrations exceeded the $1,000 \mathrm{pCi} / \mathrm{L}$ derived concentration guidelines in wells within the 100-K, 100-N, and 200-East Areas and in wells near the former Gable Mountain Pond area. The most widespread contamination and highest levels of strontium-90 contamination are found in 
the 100-N Area. At present, the overall extent of the 100-N Area strontium-90 plume is not increasing perceptibly. A pump-and-treat system is currently in operation in the 100-N Area to reduce the flux of strontium-90 to the Columbia River. Within the 200-Area plateau, the largest concentrations of strontium-90 are found in wells in the north central part of the 200-East Area, in the vicinity of the BY crib area.

\subsubsection{Assumptions and Initial Conditions}

The overall approach for modeling of future transport of the strontium-90 plumes was to initiate the simulation from 1996 conditions and calculate future transport of strontium-90 based on the threedimensional transient-flow field discussed in Section 4.3.2. For purposes of this analysis, no further contributions of strontium-90 were considered. As in the case of iodine-129, technetium-99, and uranium, future releases of strontium-90 are being estimated and analyzed as part of the Hanford Site Composite Analysis.

Initial conditions used for the strontium- 90 plume were defined based on the extent of the strontium-90 plume in 1996. Because no additional discharges of strontium- 90 were assumed to occur, the area defined by the 1995 plume is sufficient to represent the maximum extent of that plume. The initial conditions for the strontium-90 plume were generated in the same manner as initial conditions for the tritium plume (i.e., the 1995 plume was used as an initial condition). It was found that the same threedimensional grid defined for the 200-Area tritium plume (Figure 5.1) could be used for the strontium-90 plume. The 1996 strontium-90 concentrations used as initial conditions are presented in Figure 5.25.

\subsubsection{Results and Discussion}

Transport model results for strontium-90 from 1996 through 2300, as shown in Figures 5.26, 5.27, 5.28 , and 5.29, demonstrate that the current strontium-90 plume will likely migrate very little from its current location within the 200-East Area because strontium-90 is adsorbed to Hanford sediments. Concentration levels of the simulated plume near the BY crib area decline over the next 100 years to well below $8 \mathrm{pCi} / \mathrm{L}$ by the process of plume dispersion. The concentrations are further reduced by radioactive decay. 
In the 200-East Area, maximum strontium-90 levels exceed $3000 \mathrm{pCi} / \mathrm{L}$ and decline to less than $3000 \mathrm{pCi} / \mathrm{L}$ in 2000 , to less than $500 \mathrm{pCi} / \mathrm{L}$ by 2031 , to less than $50 \mathrm{pCi} / \mathrm{L}$ by the year 2100 , and to below the interim DWS of $8 \mathrm{pCi} / \mathrm{L}$ by the year 2200. Maximum strontium-90 levels exceeding $8 \mathrm{pCi} / \mathrm{L}$, simulated in the Gable Mountain Pond area north of the 200-East Area, decline to less than $8 \mathrm{pCi} / \mathrm{L}$ by 2011 and less than $0.8 \mathrm{pCi} / \mathrm{L}$ by 2100 .

Groundwater containing elevated strontium-90 levels in the $100-\mathrm{K}$ and $100-\mathrm{N}$ areas is expected to migrate into the Columbia River within the next 100 years before decaying to levels below regulatory concern. Strontium-90 transport at these specific locations was not specifically considered in this analysis. 


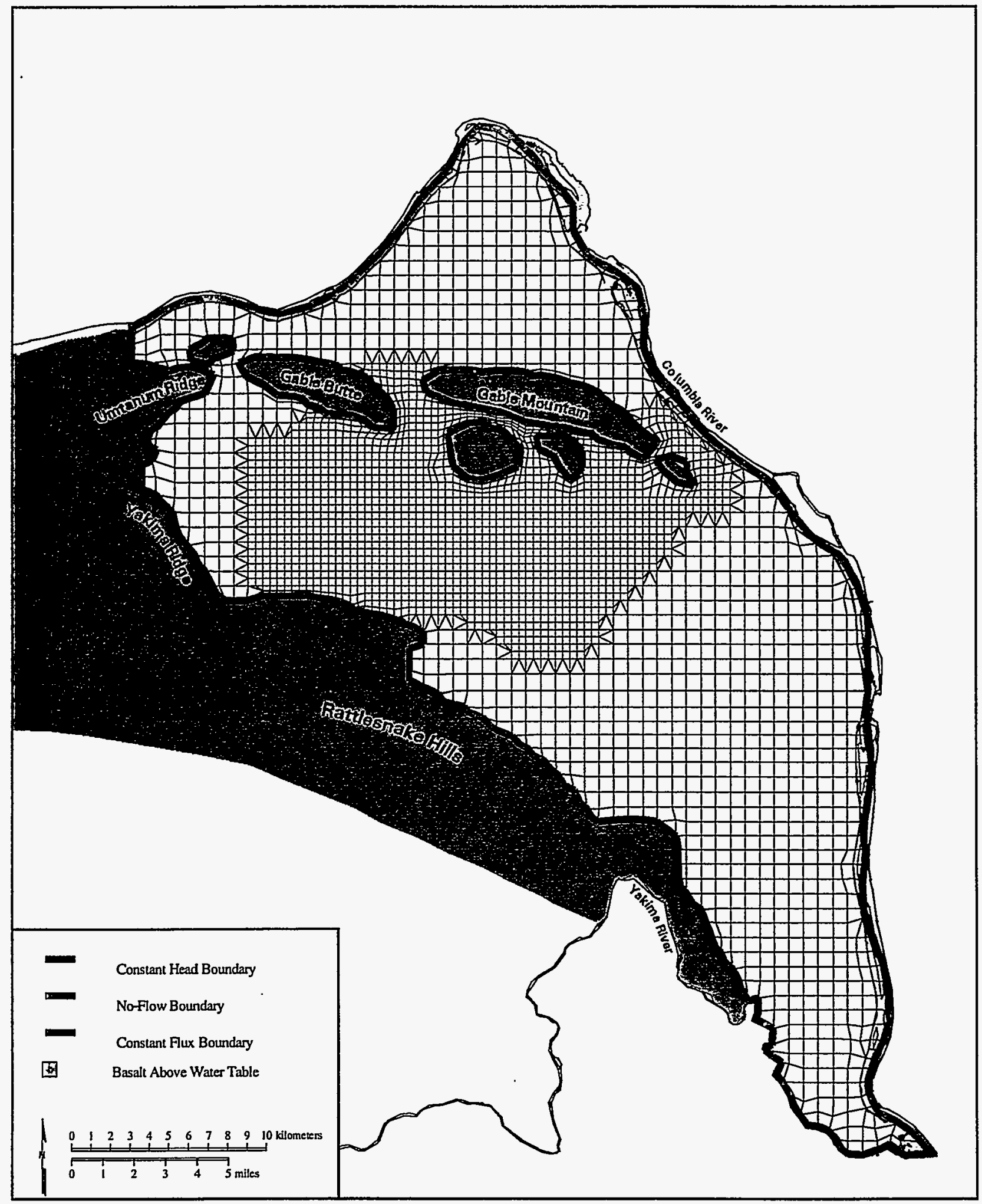

97skw026.eps December 01, 1997

Figure 5.1. Refined Finite-Element Grid Used for Three-Dimensional Transport Simulations 


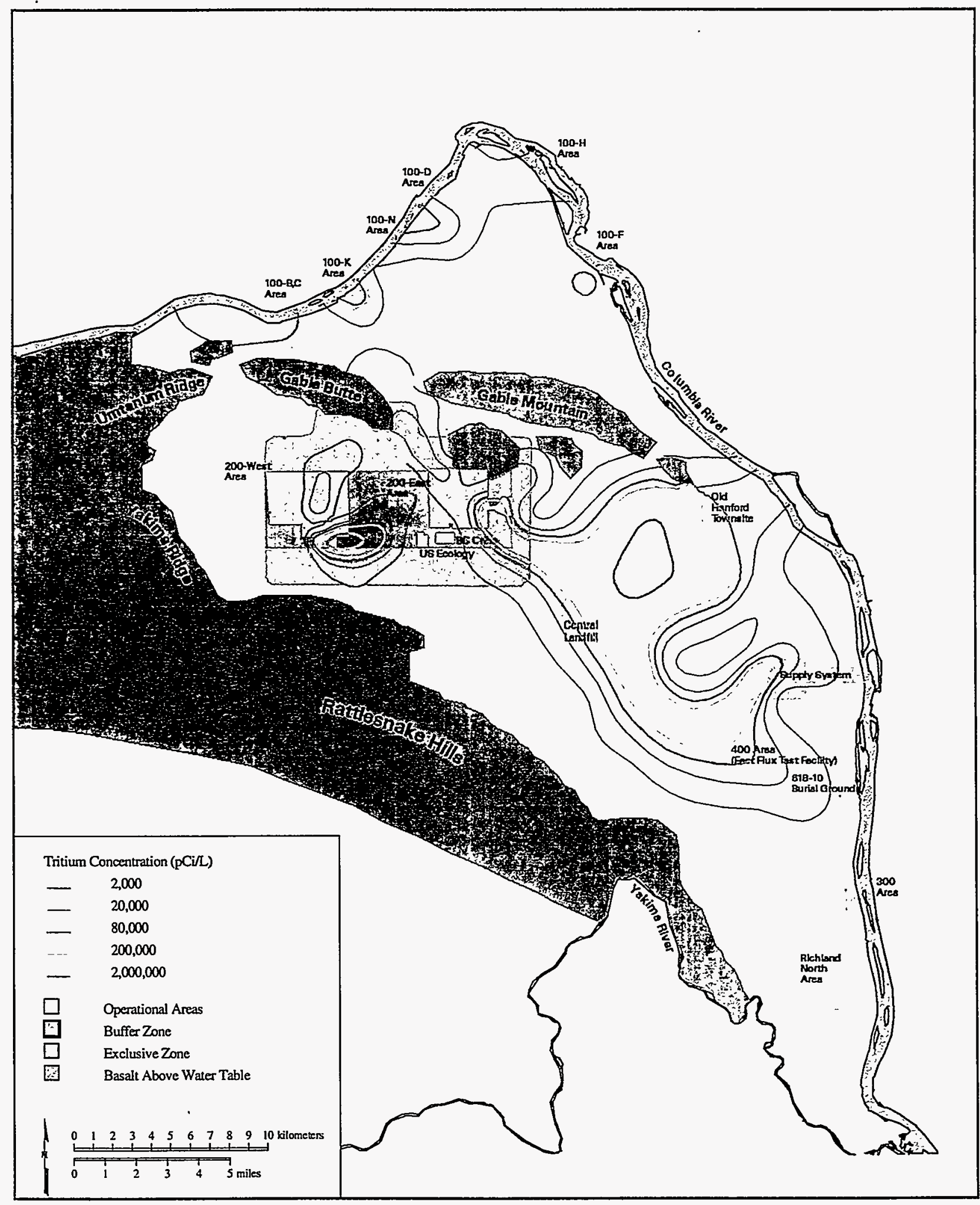

97skw027.eps December 30, 1997

Figure 5.2. Areal Distribution of Tritium Used as Initial Conditions for Transport Modeling 


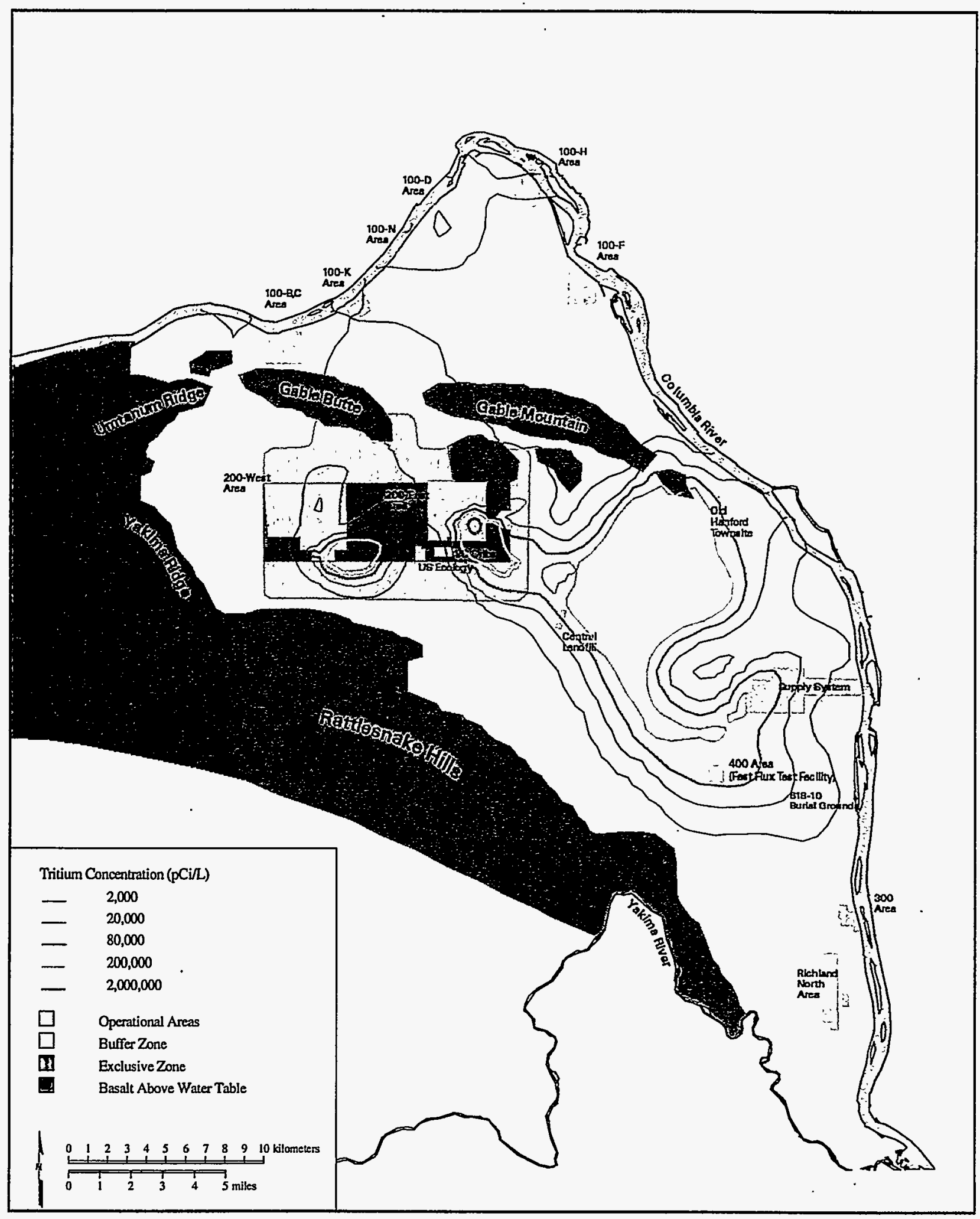

97skw031.eps December 30, 1997

Figure 5.3. Areal Distribution of Tritium in 1985 as Predicted with the Three-Dimensional Transport Model 


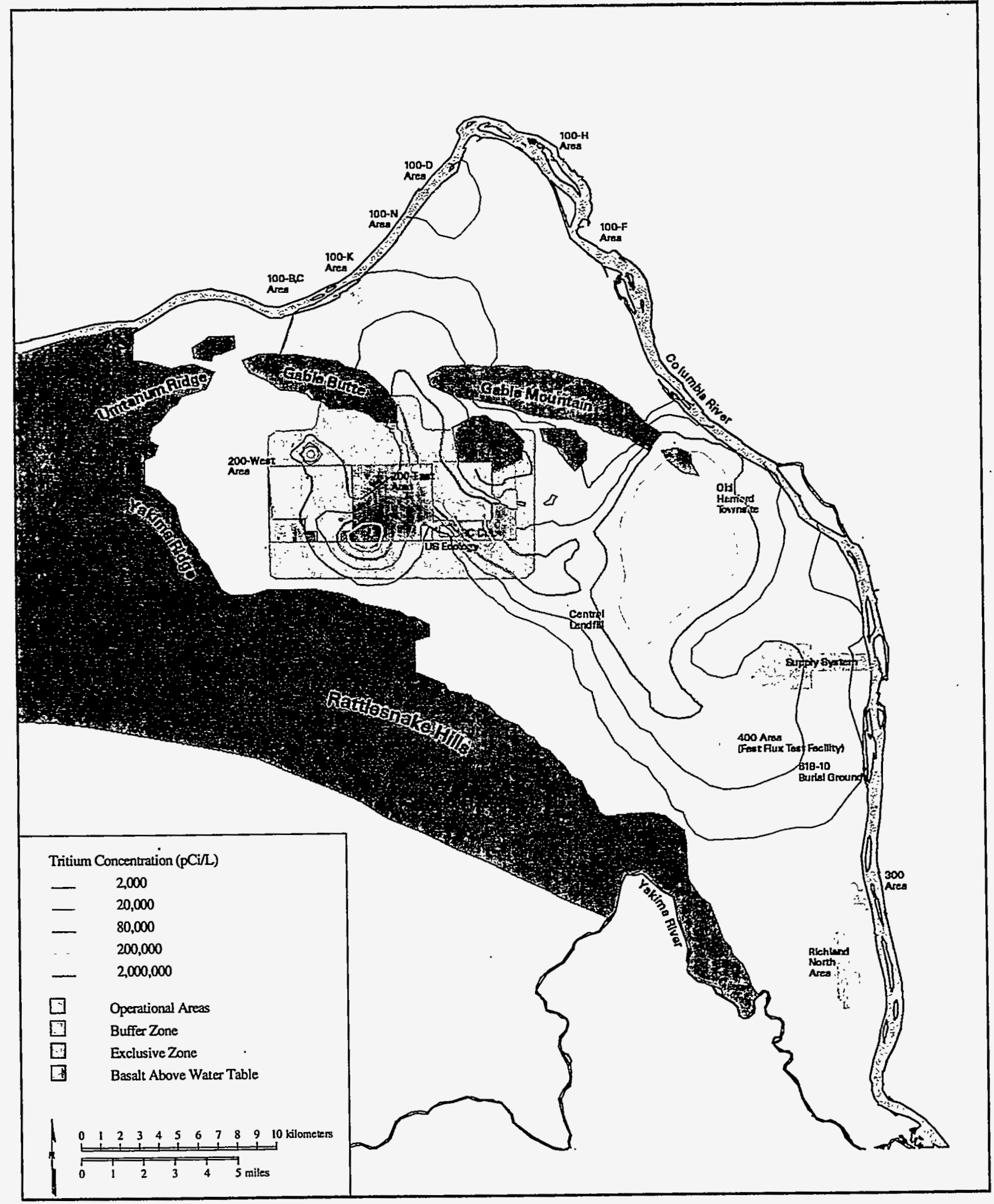

97skw032.cps December 30, 1997

Figure 5.4. Areal Distribution of Tritium in 1996 as Predicted with the Three-Dimensional Transport Model 


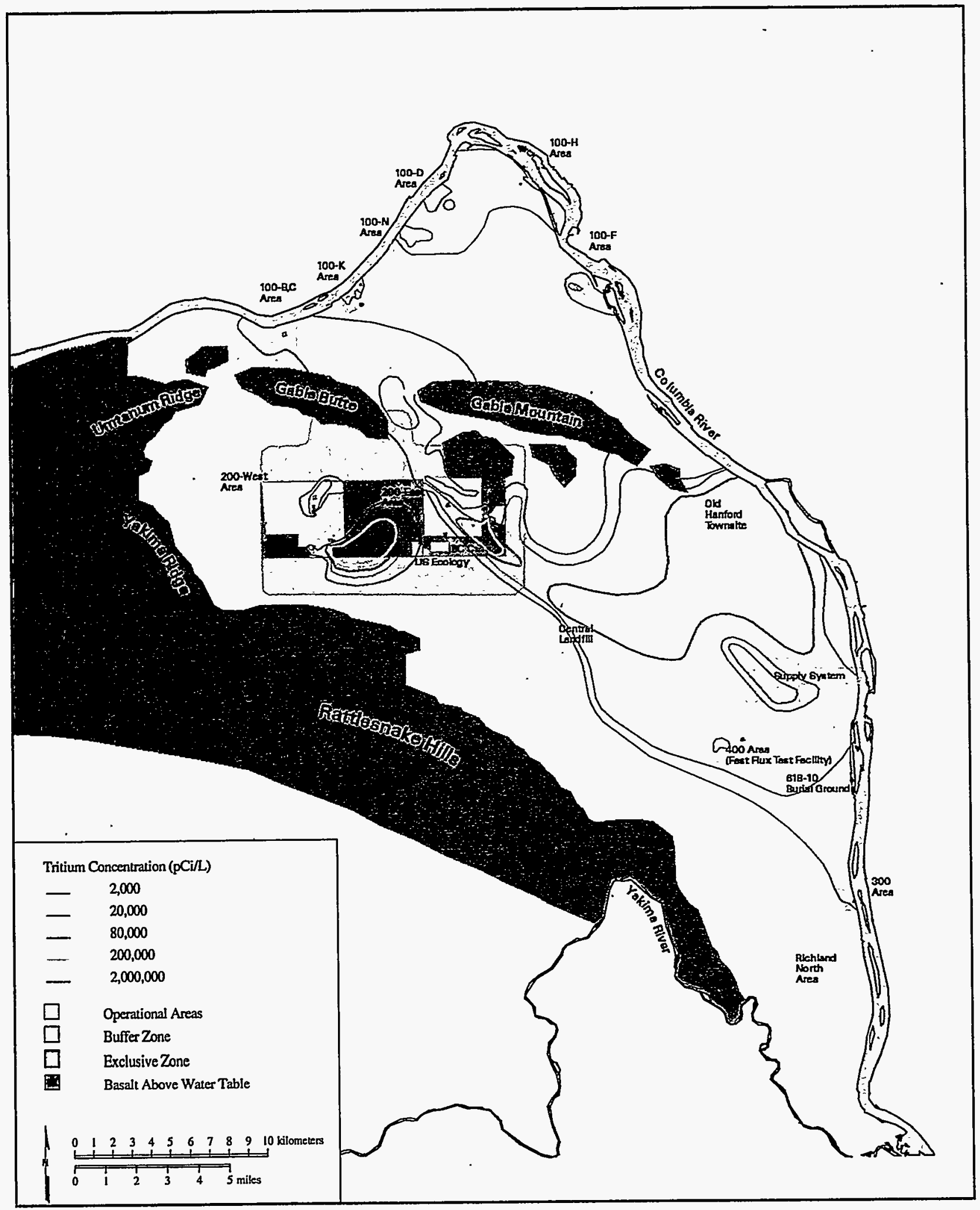

97skw030.eps December 30, 1997

Figure 5.5. Observed Tritium for 1996 Conditions 


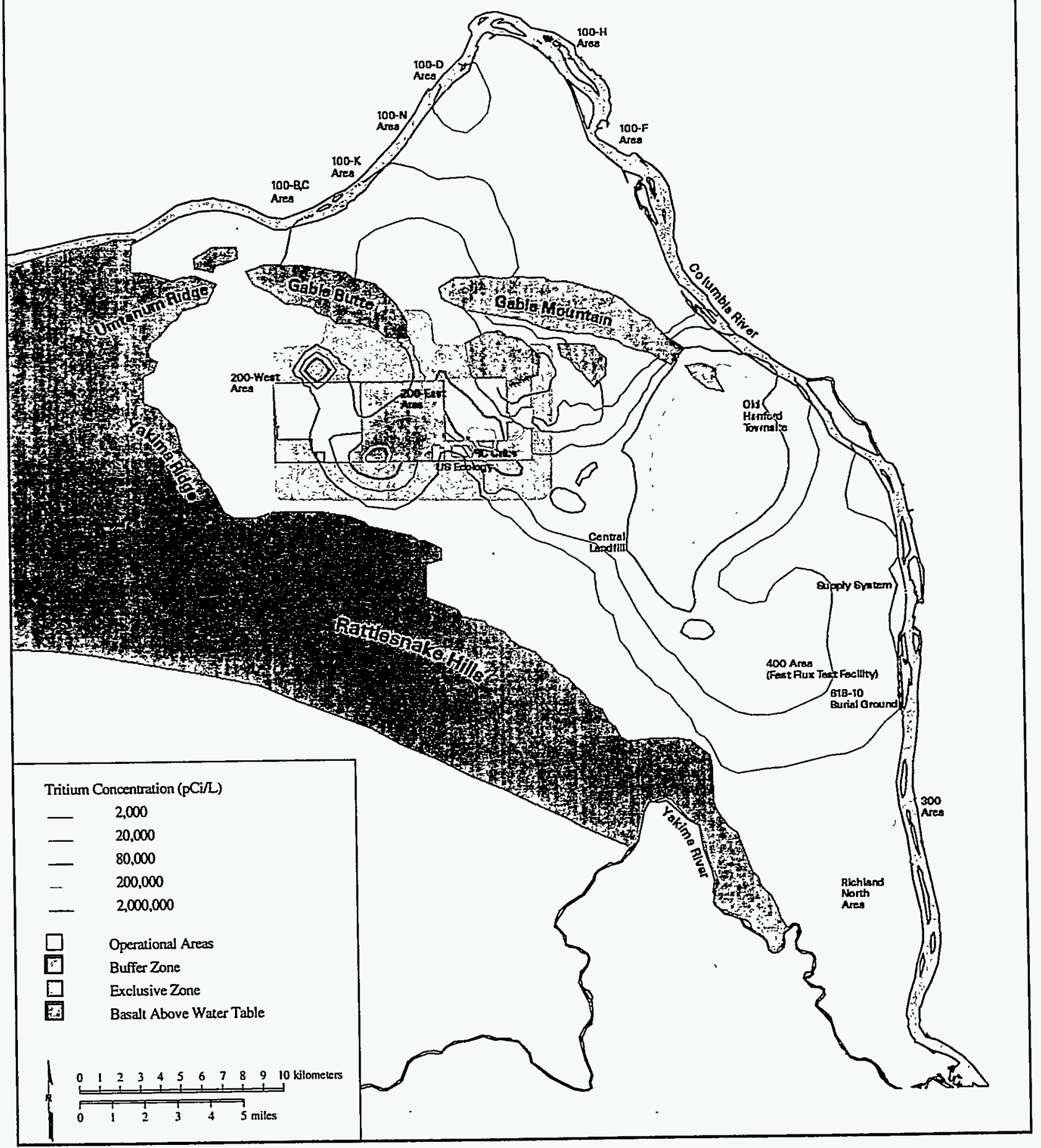

97skw033.eps December 31, 1997

Figure 5.6. Areal Distribution of Tritium in 2000 as Predicted with the Three-Dimensional Transport Model 


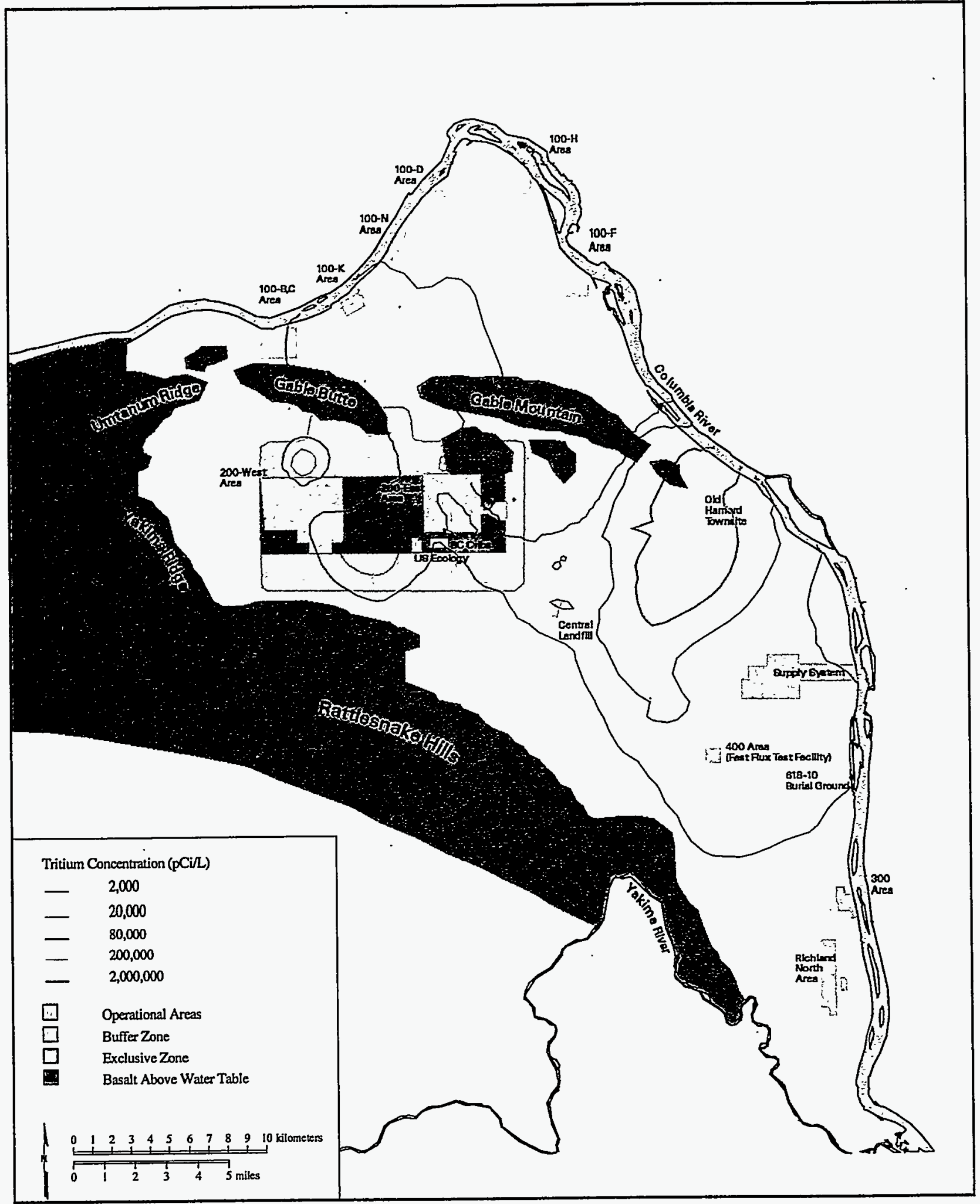

97skw034.cps December 30, 1997

Figure 5.7. Areal Distribution of Tritium in 2020 as Predicted with the Three-Dimensional Transport Model 


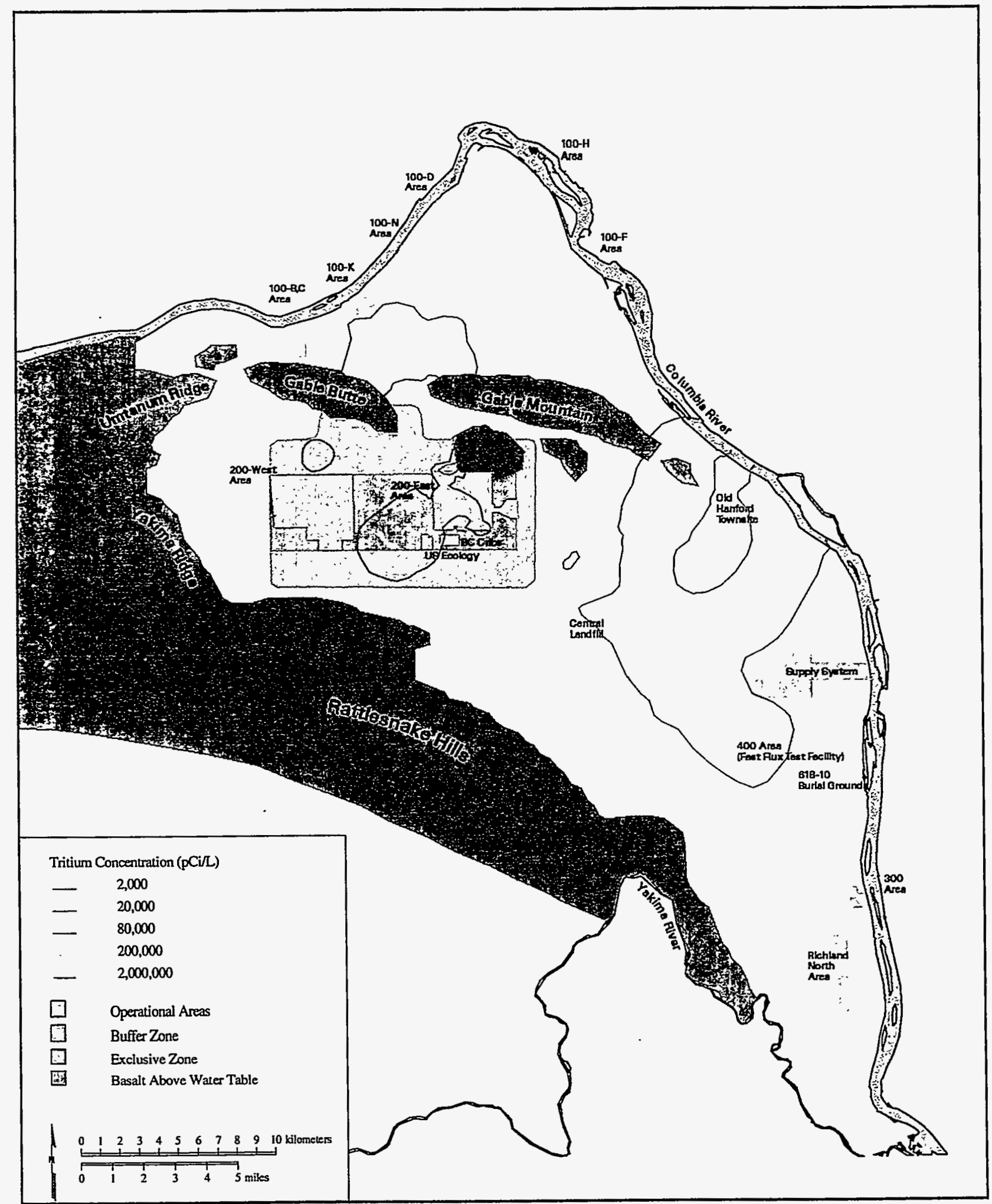

97skw035.cps December 30, 1997

Figure 5.8. Areal Distribution of Tritium in 2050 as Predicted with the Three-Dimensional Transport Model 


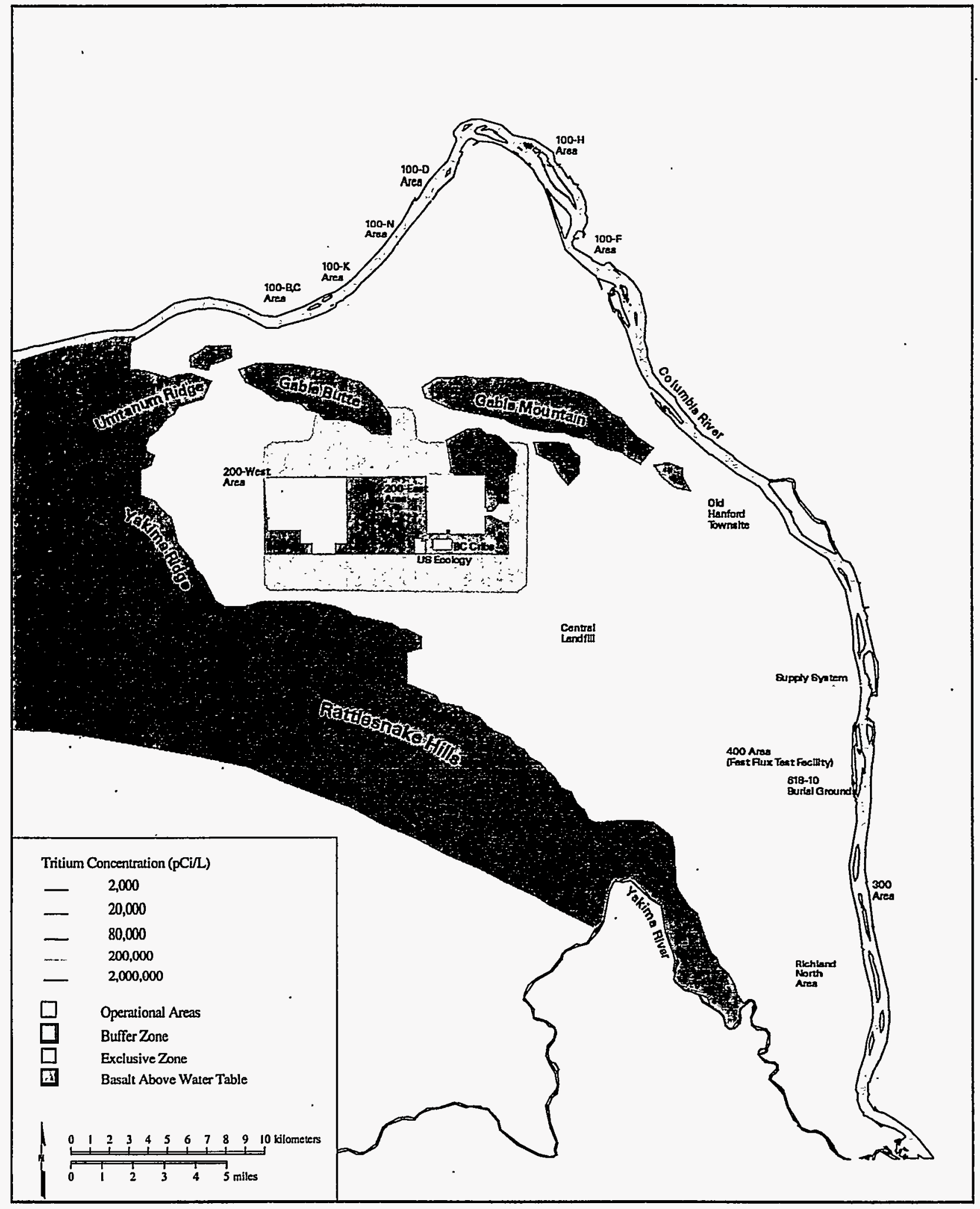

97skw036.eps December 31. 1997

Figure 5.9. Areal Distribution of Tritium in 2100 as Predicted with the Three-Dimensional Transport Model 


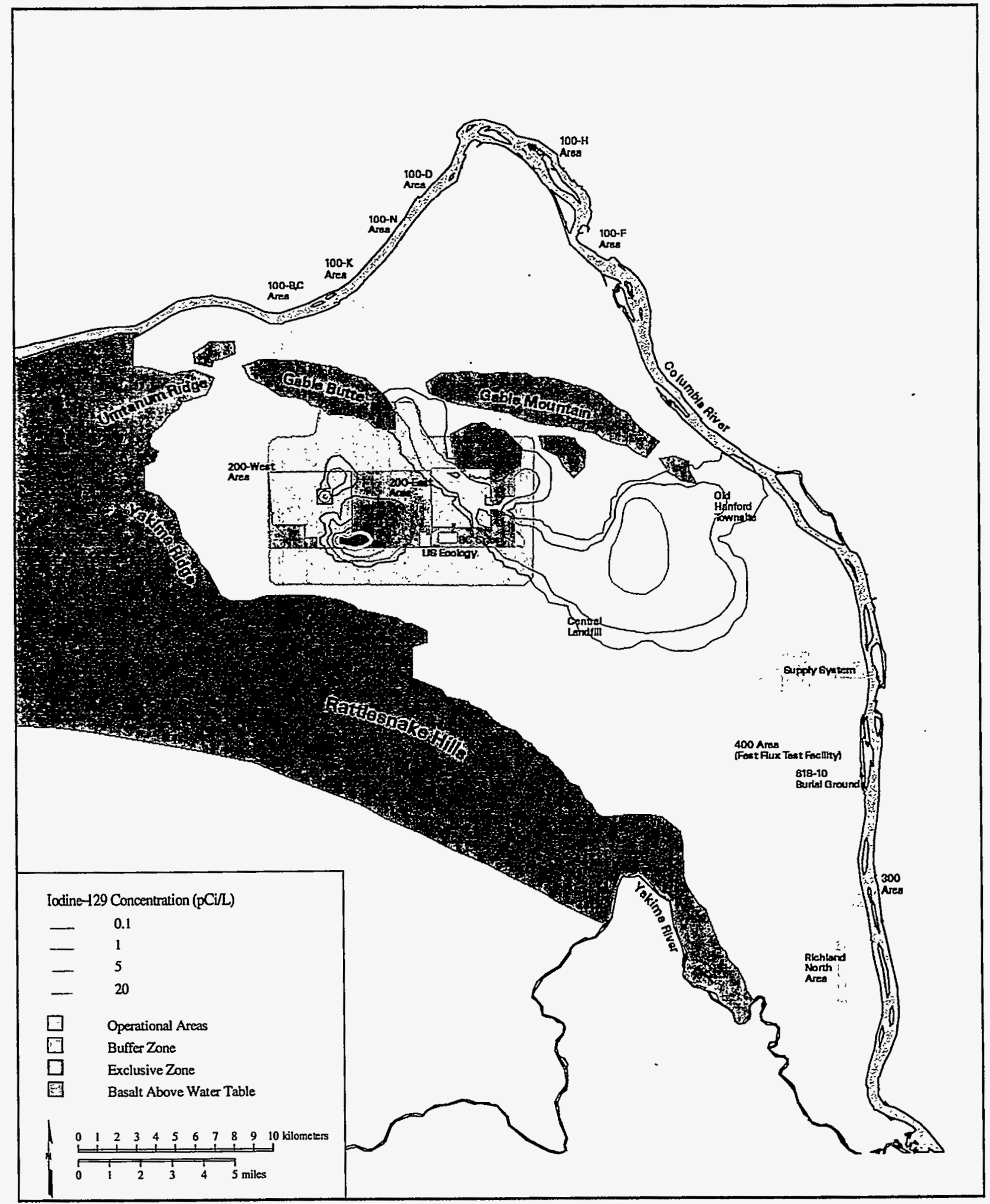

97skw037.eps Decomber 30, 1997

Figure 5.10. Areal Distribution of Iodine-129 Used as Initial Conditions for Transport Modeling 


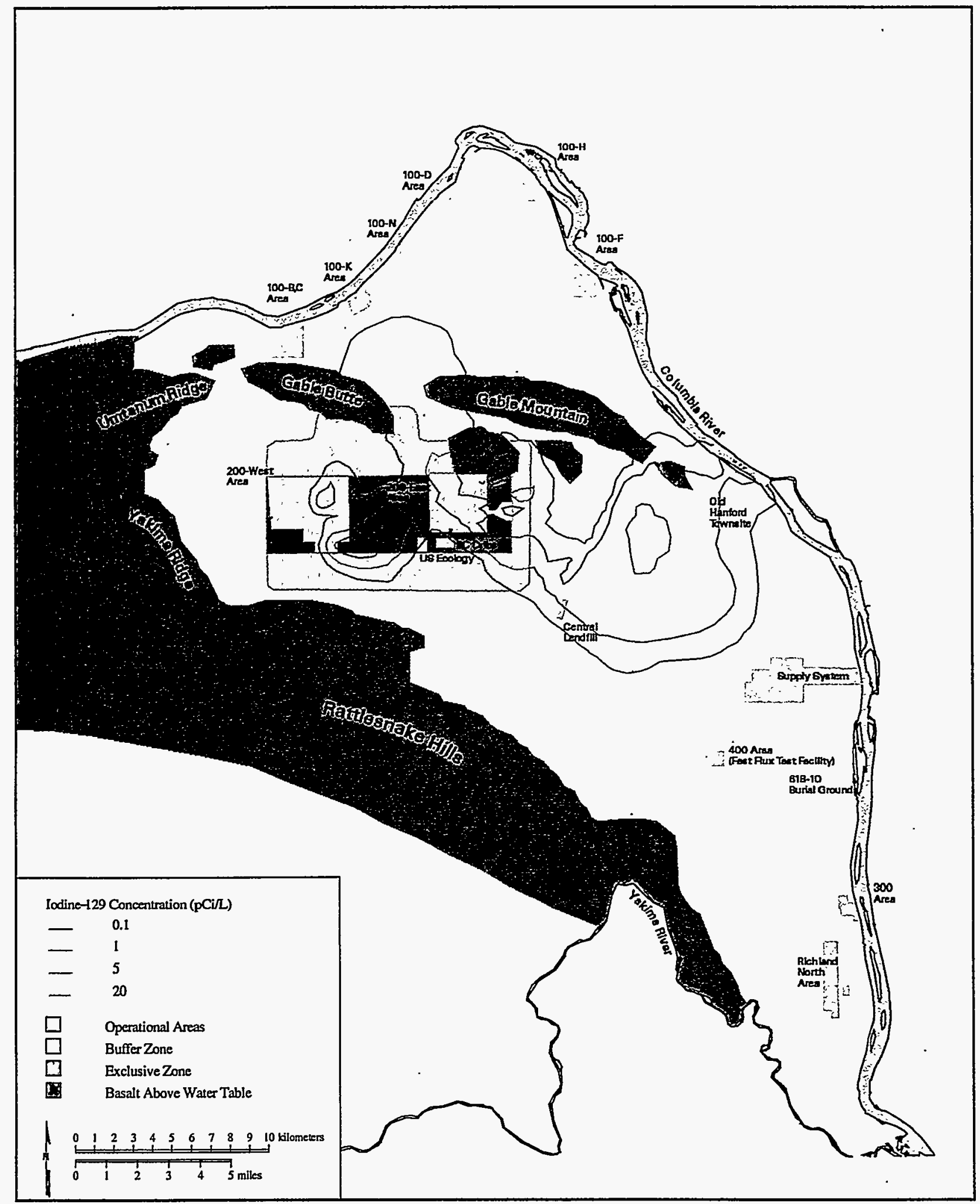

97skw038.eps Decomber 30, 1997

Figure 5.11. Areal Distribution of Iodine-129 in 2031 as Predicted with the Three-Dimensional Model 


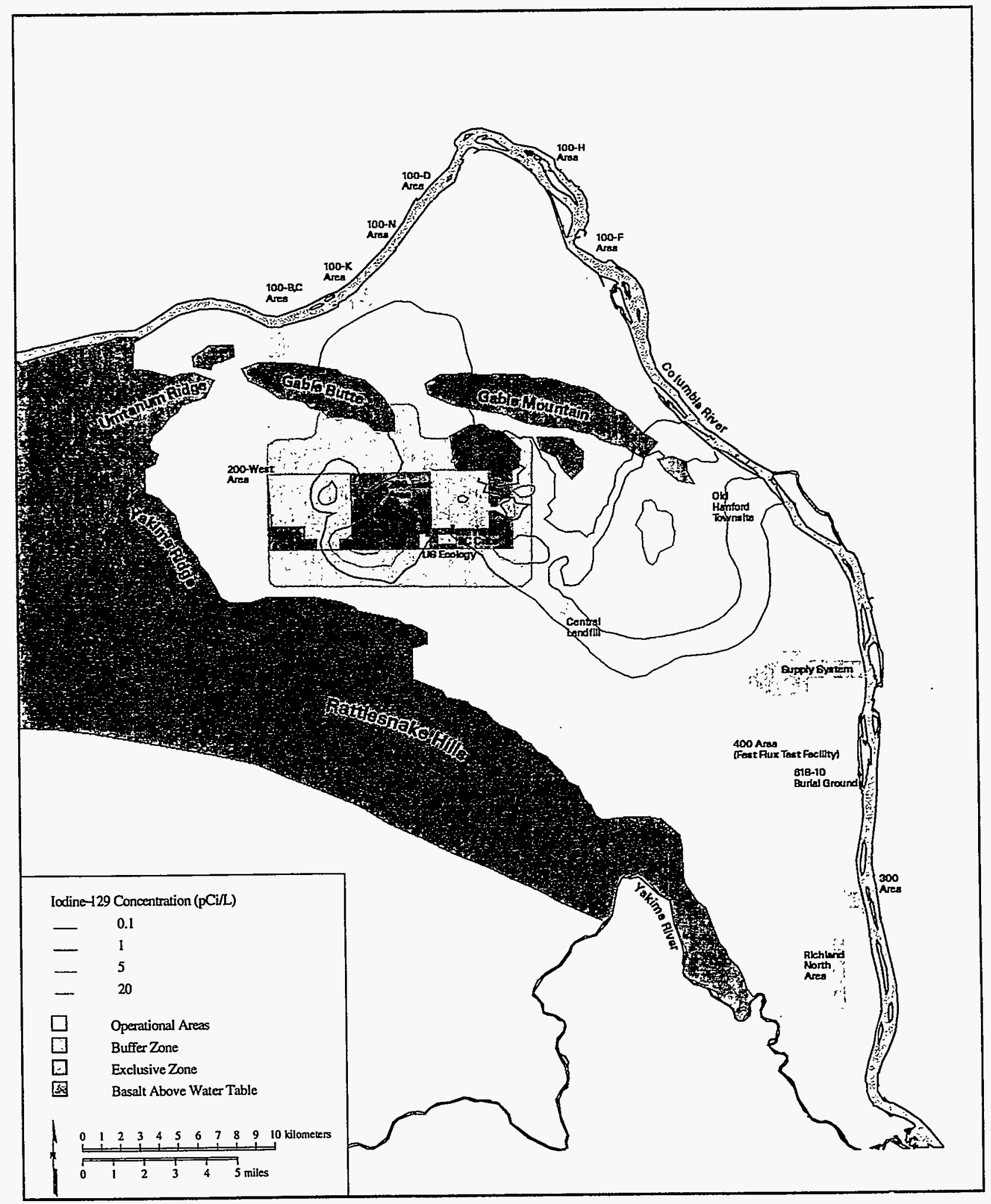

97skw039.eps December 30. 1997

Figure 5.12. Areal Distribution of Iodine-129 in 2049 as Predicted with the Three-Dimensional Model 


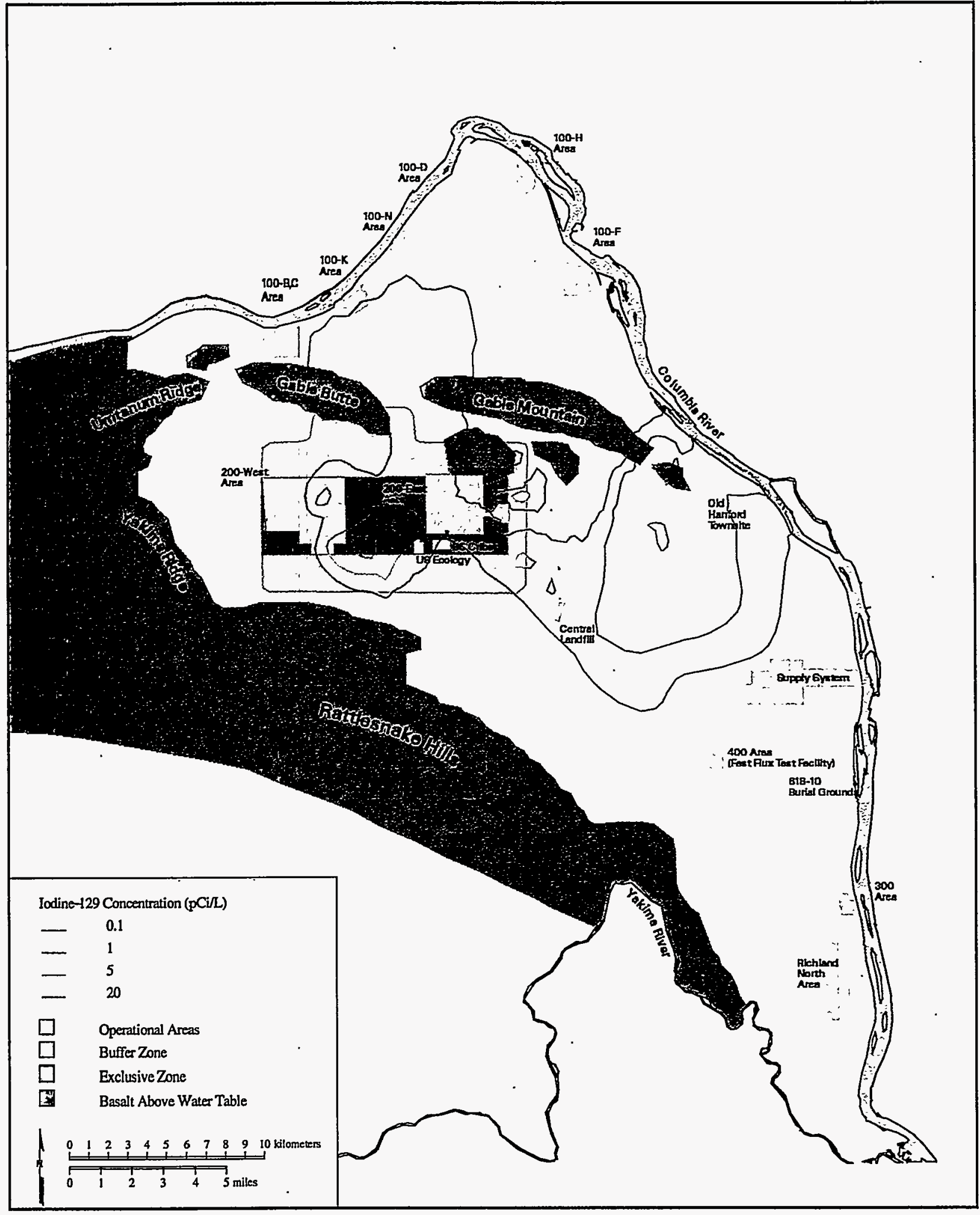

97skw040.eps December 30, 1997

Figure 5.13. Areal Distribution of Iodine-129 in 2099 as Predicted with the Three-Dimensional Model 


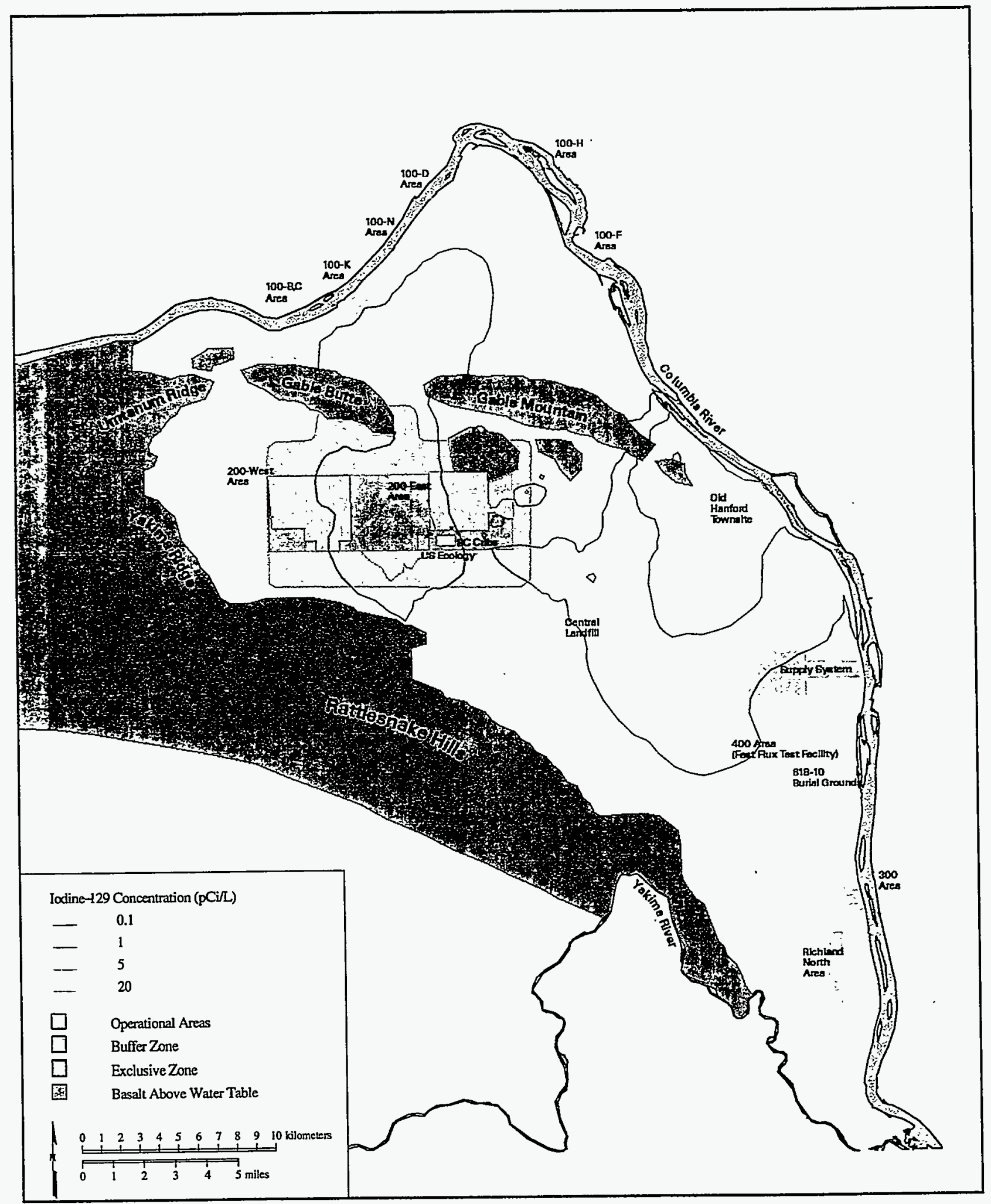

97skw041.cps December 30, 1997

Figure 5.14. Areal Distribution of Iodine-129 in 2299 as Predicted with the Three-Dimensional Model 


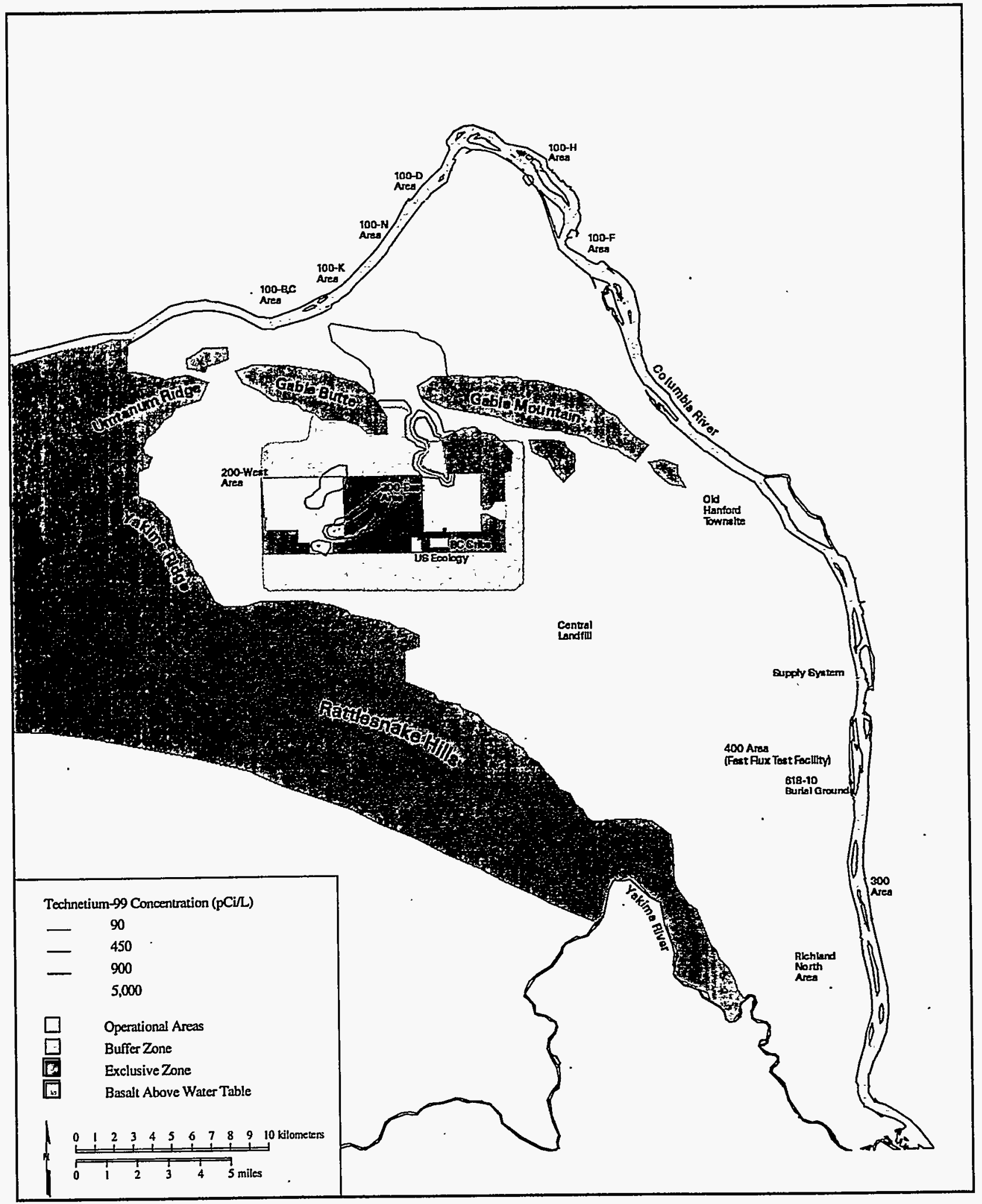

97skw042.eps December 31, 1997

Figure 5.15. Areal Distribution of Technetium-99 Used as Initial Conditions for Transport Modeling 


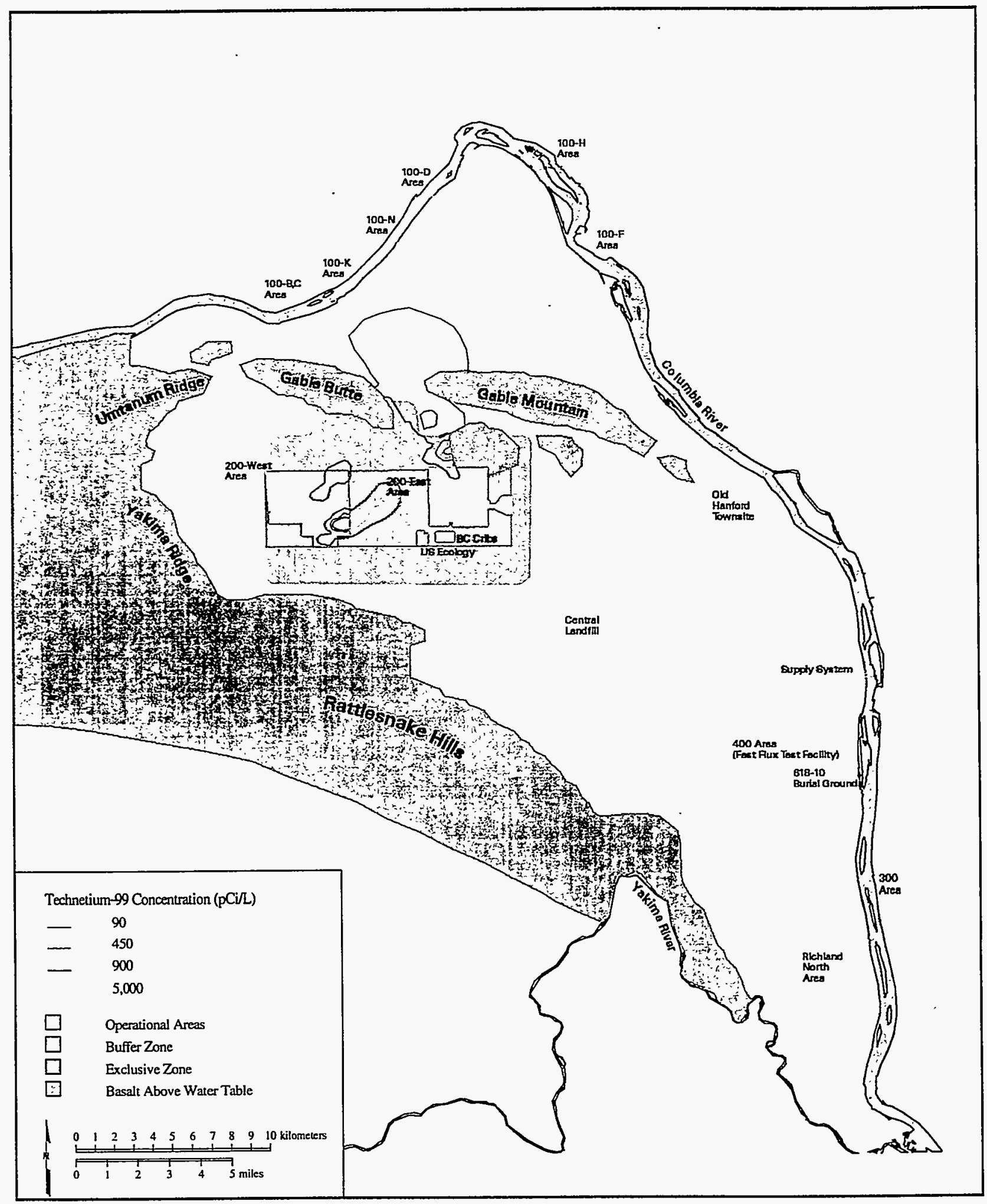

97skw043.eps December 31, 1997

Figure 5.16. Areal Distribution of Technetium-99 in 2000 as Predicted with the Three-Dimensional Model 


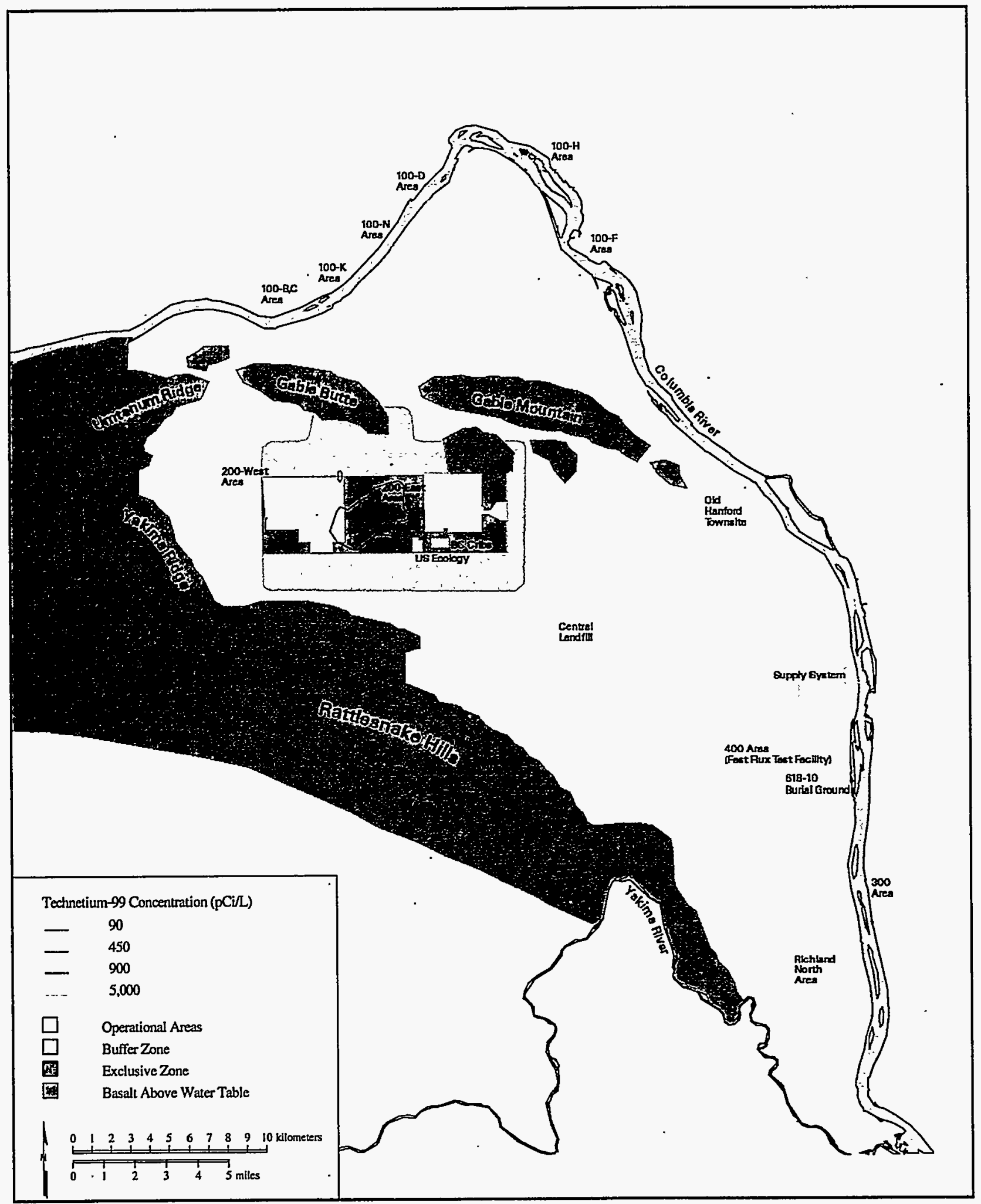

97skw044.eps December 31, 1997

Figure 5.17. Areal Distribution of Technetium-99 in 2031 as Predicted with the Three-Dimensional Model 


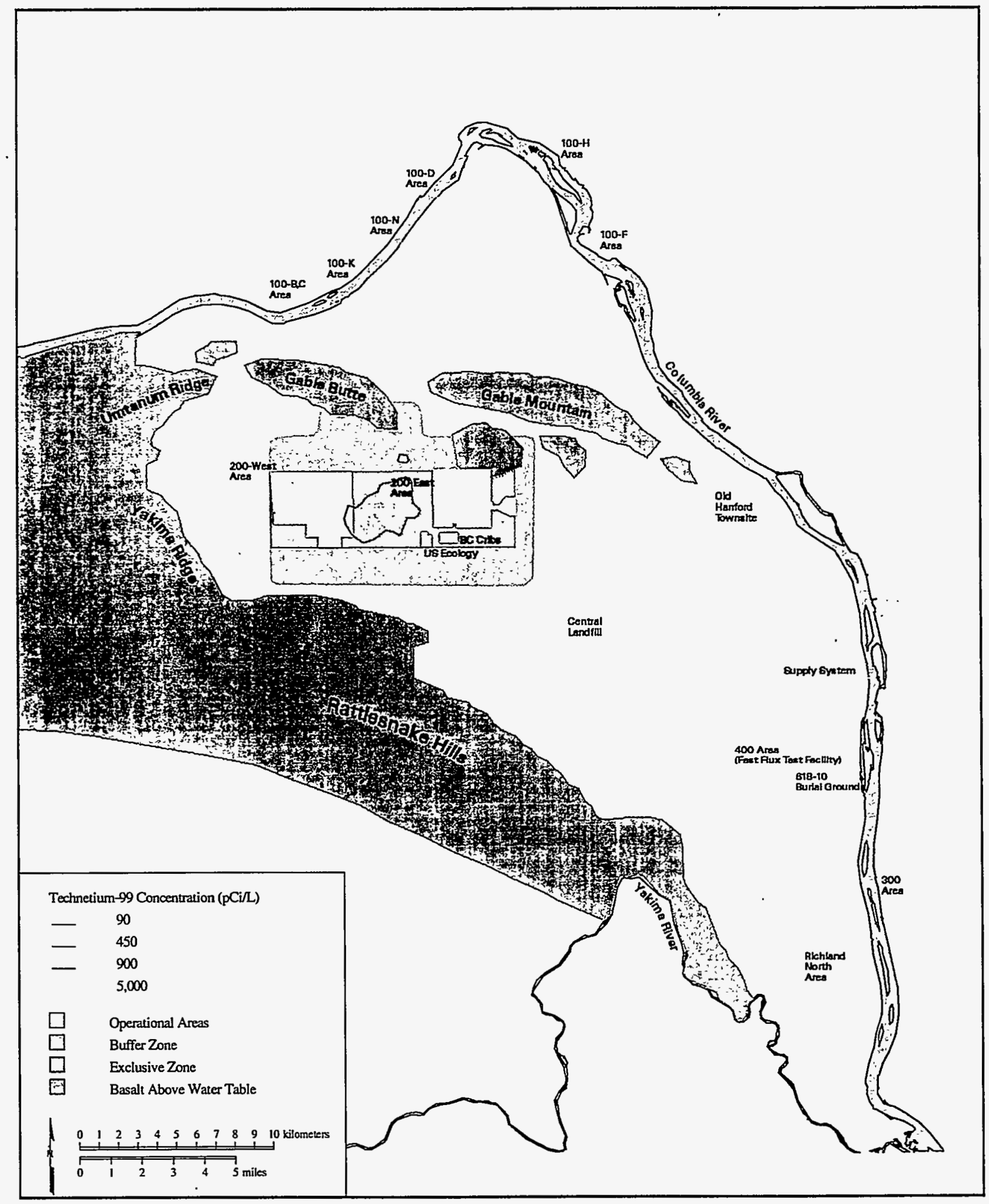

97skw045.eps December 31. 1997

Figure 5.18. Areal Distribution of Technetium- 99 in 2049 as Predicted with the Three-Dimensional Model 


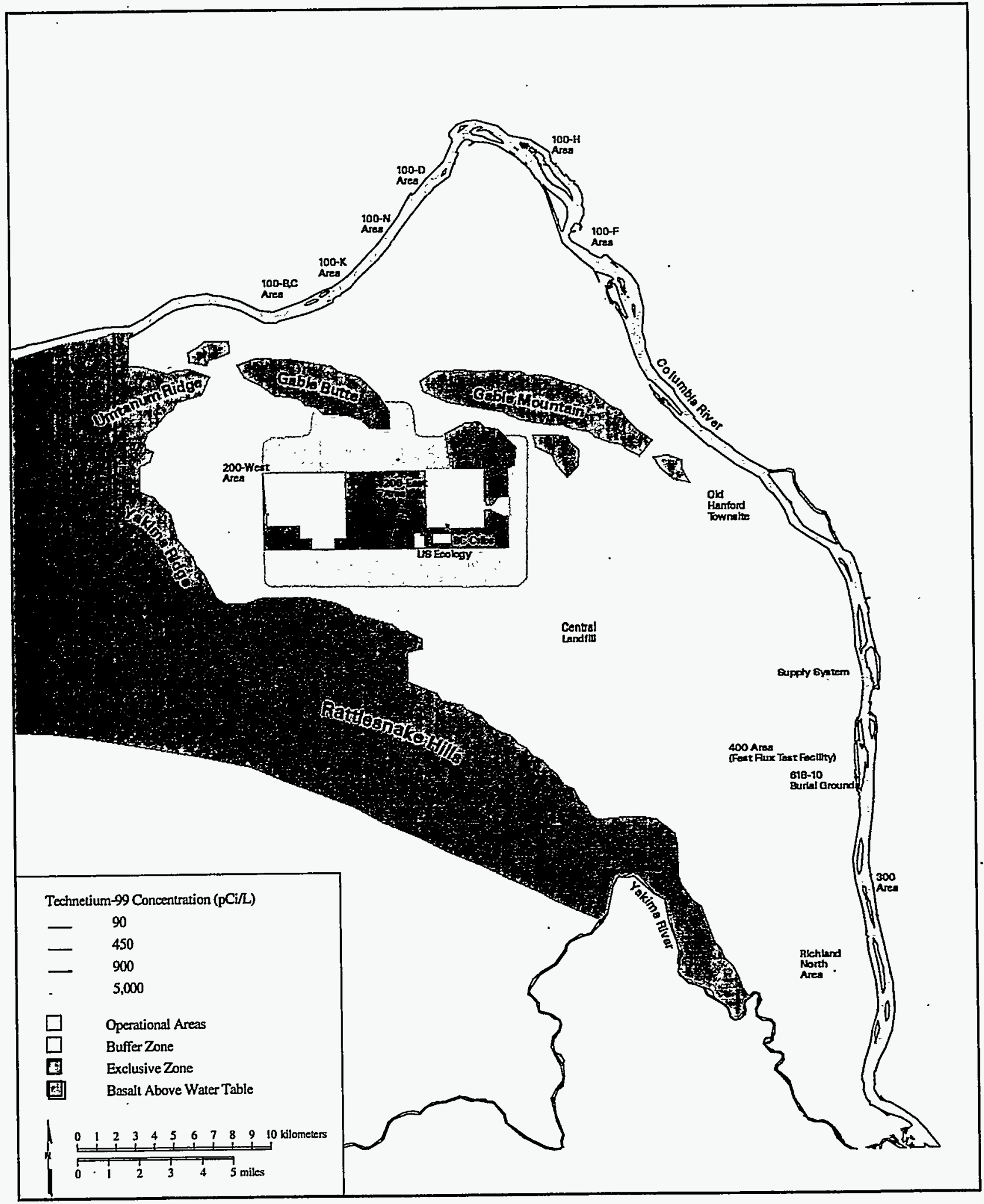

97skw046.eps December 31, 1997

Figure 5.19. Areal Distribution of Technetium-99 in 2099 as Predicted with the Three-Dimensional Model 


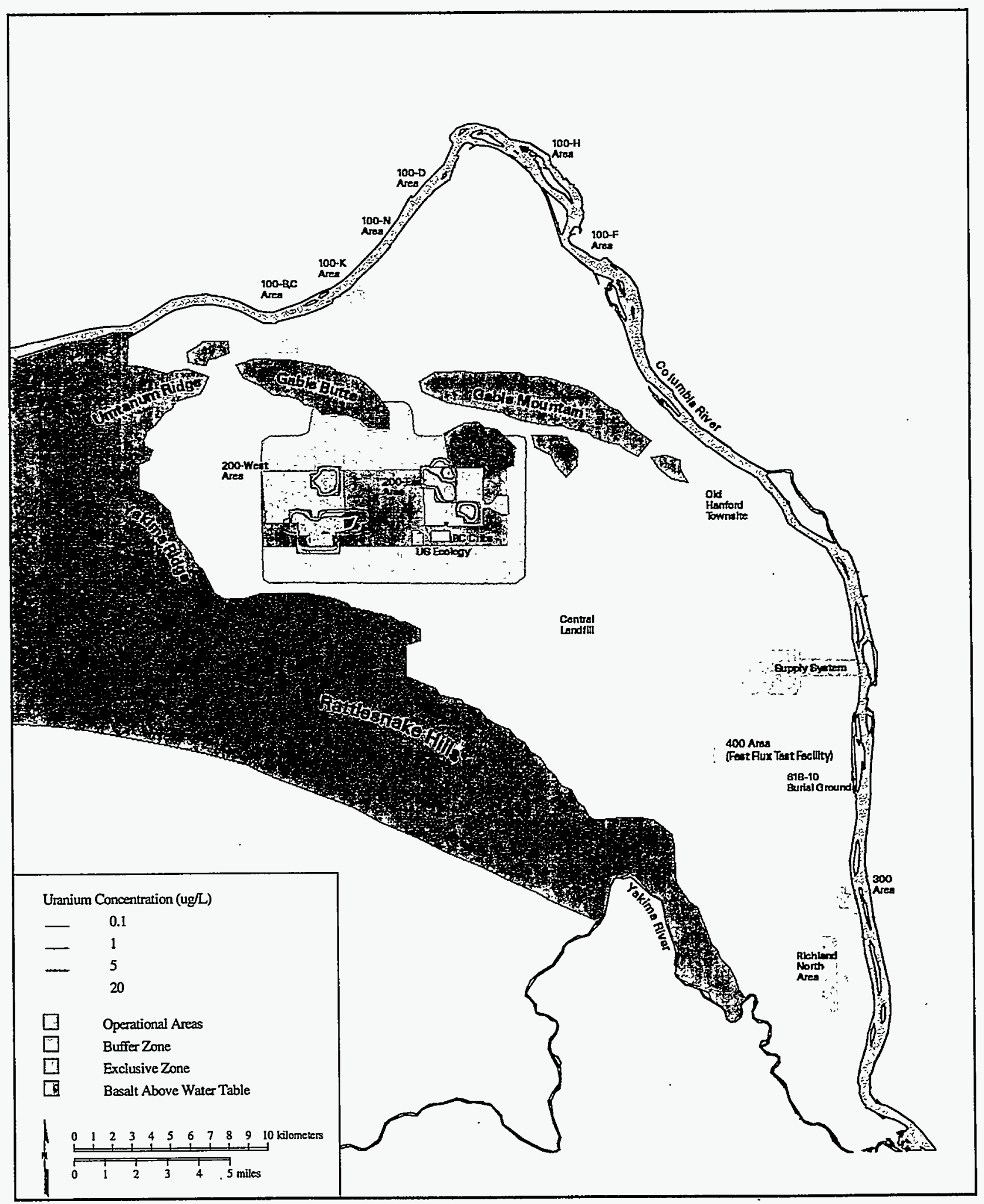

97skw048.eps December 30, 1997

Figure 5.20 Areal Distribution of Uranium Used as Initial Conditions for Transport Modeling 


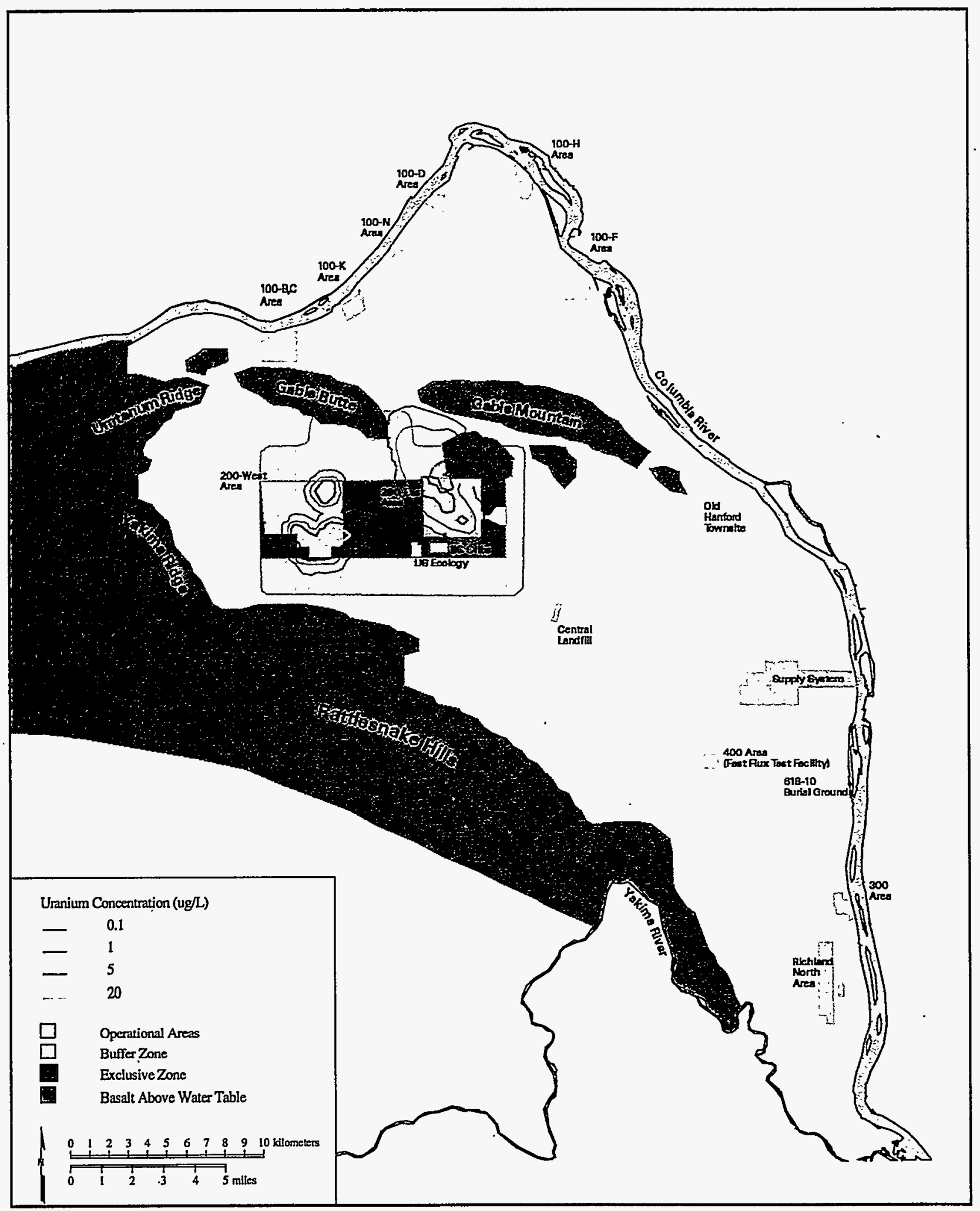

97skw049.eps Decernber 30, 1997

Figure 5.21. Areal Distribution of Uranium in 2031 as Predicted with the Three-Dimensional Model 


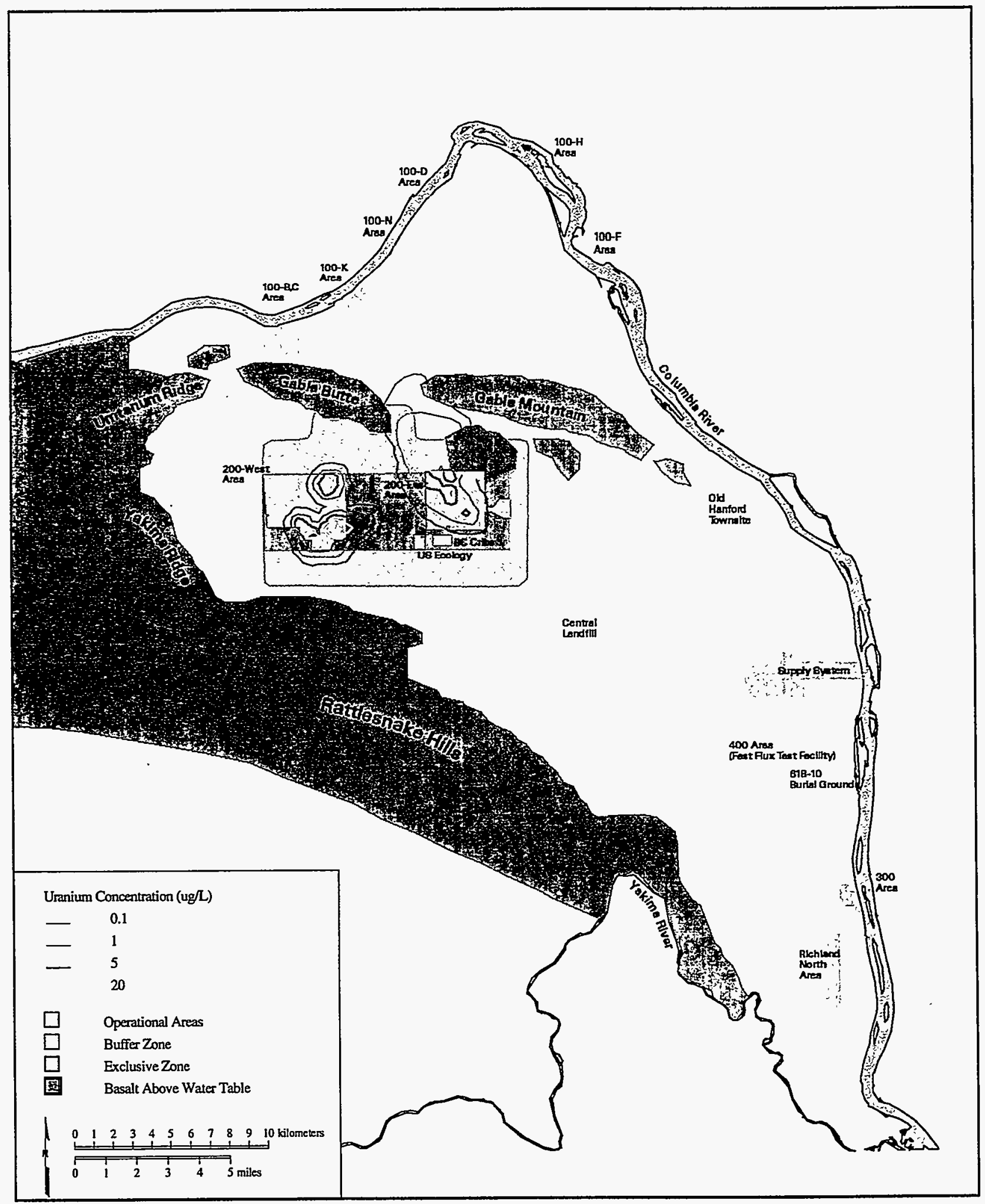

97skw050.eps December 30, 1997

Figure 5.22. Areal Distribution of Uranium in 2049 as Predicted with the Three-Dimensional Model 


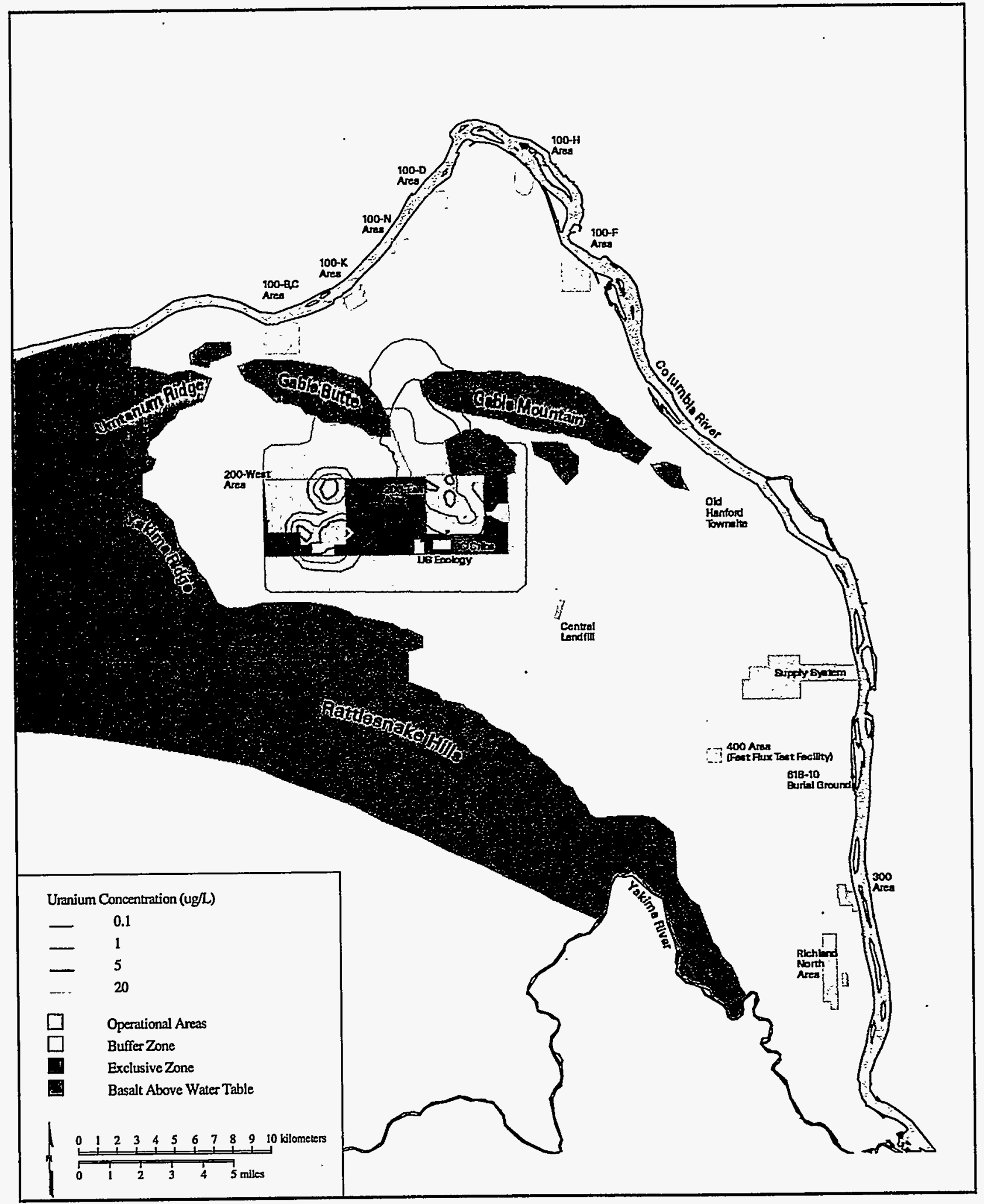

97skw051.cps December 30, 1997

Figure 5.23. Areal Distribution of Uranium in 2099 as Predicted with the Three-Dimensional Model 


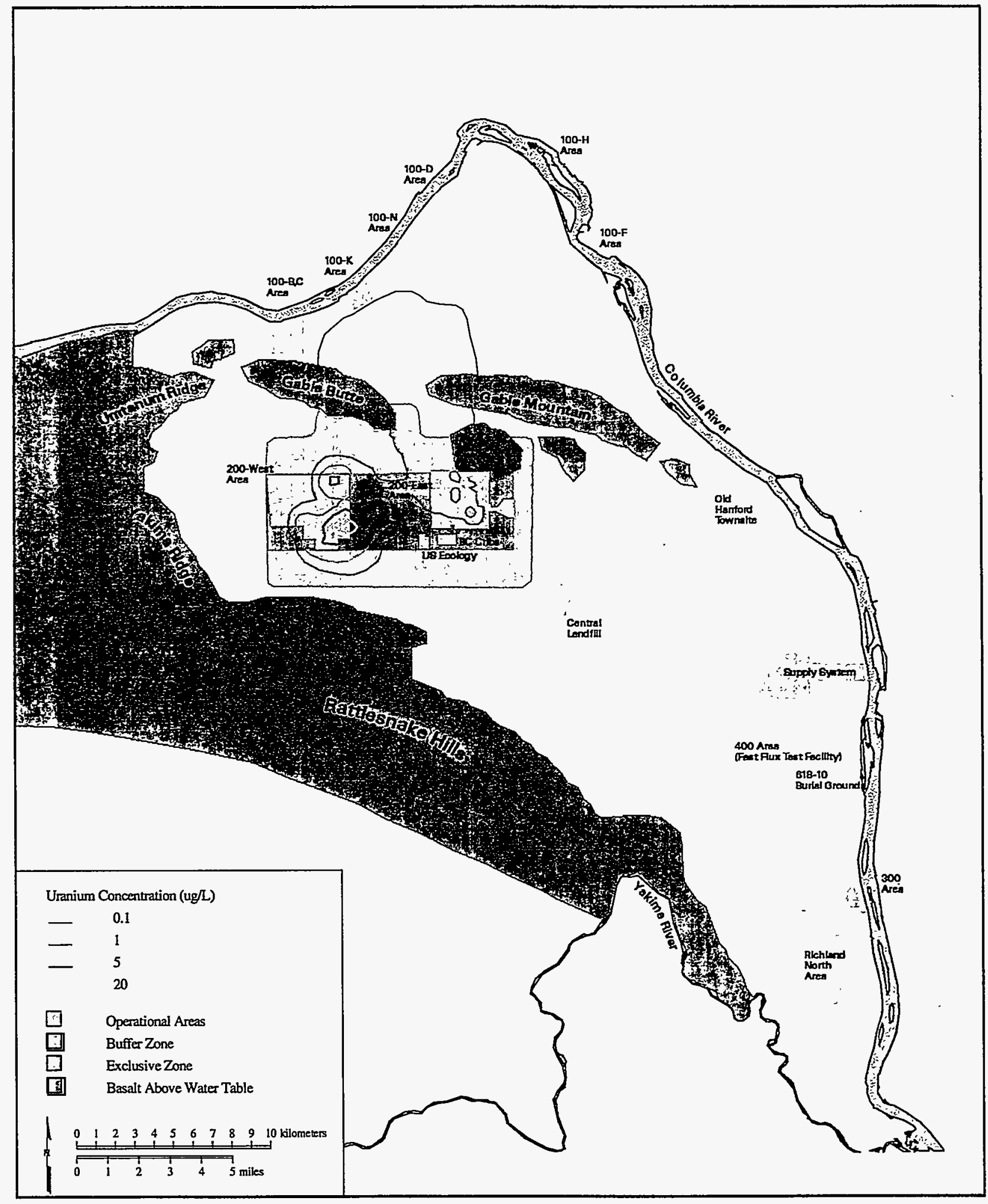

97skw052.eps December 30, 1997

Figure 5.24. Areal Distribution of Uranium in 2299 as Predicted with the Three-Dimensional Model 


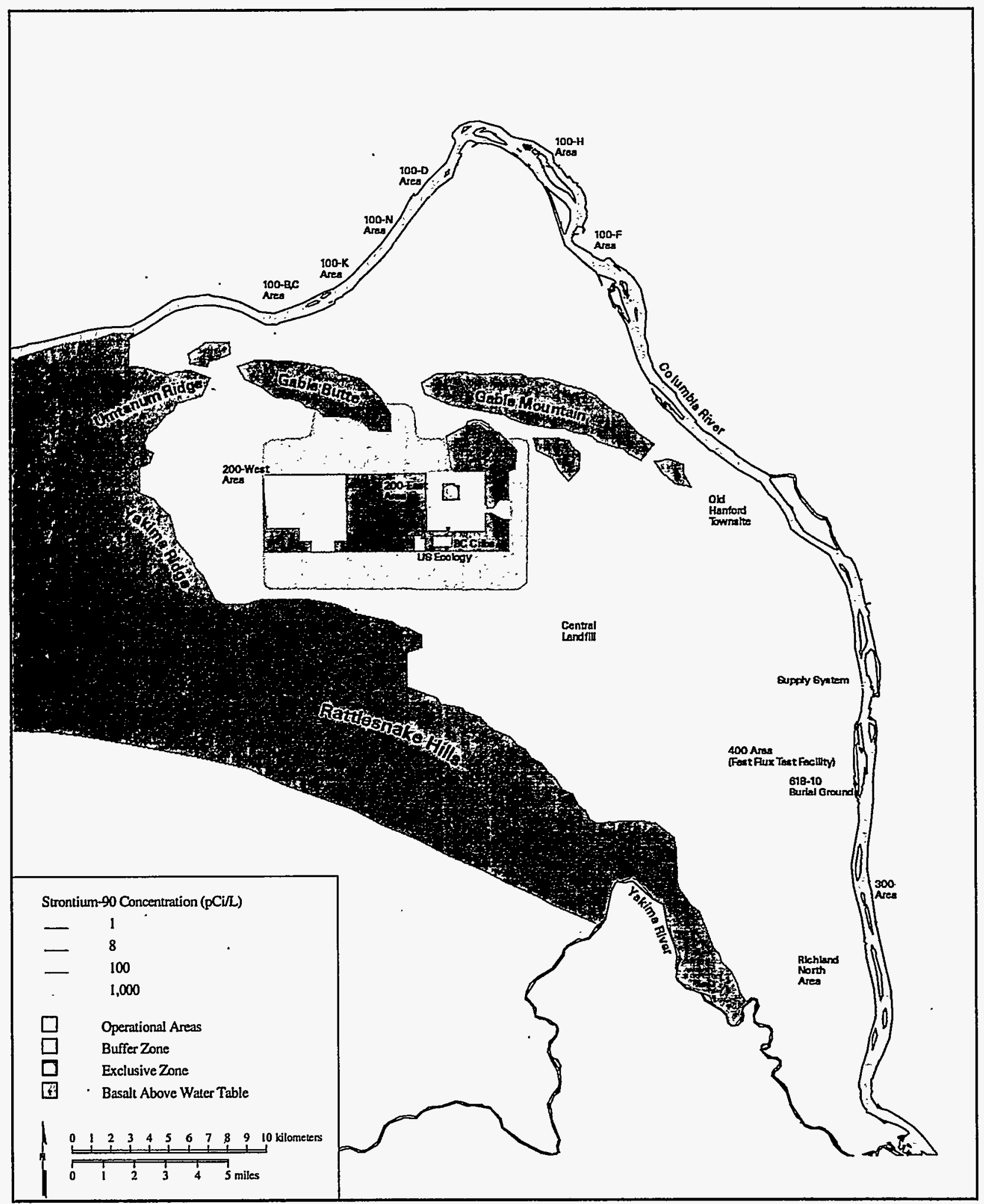

97skw053.eps December 31. 1997

Figure 5.25. Areal Distribution of Strontium-90 Used as Initial Conditions for Transport Modeling 


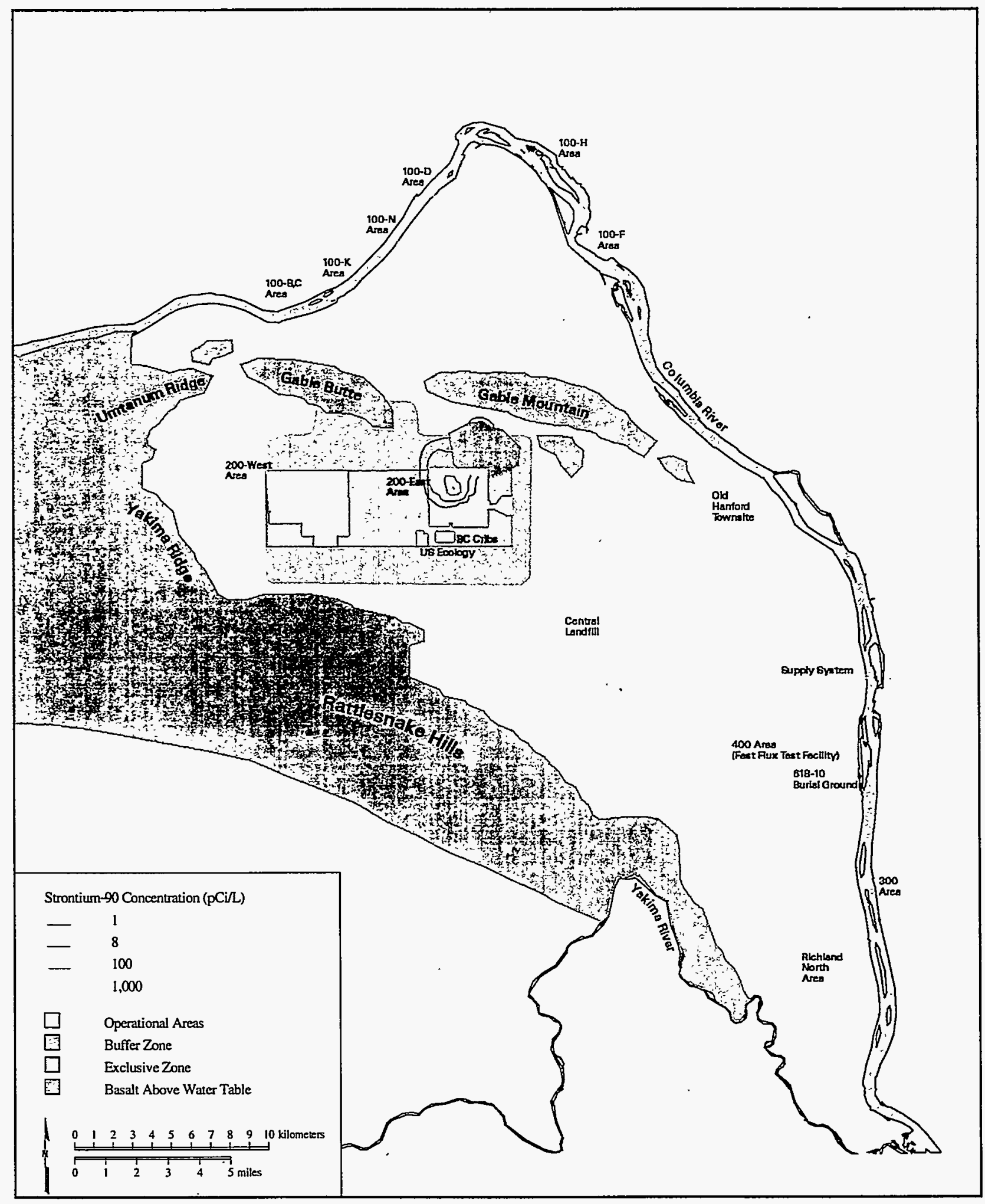

97skw054.eps December 31. 1997

Fgure 5.26. Areal Distribution of Strontium-90 in 2031 as Predicted with the Three-Dimensional Model 


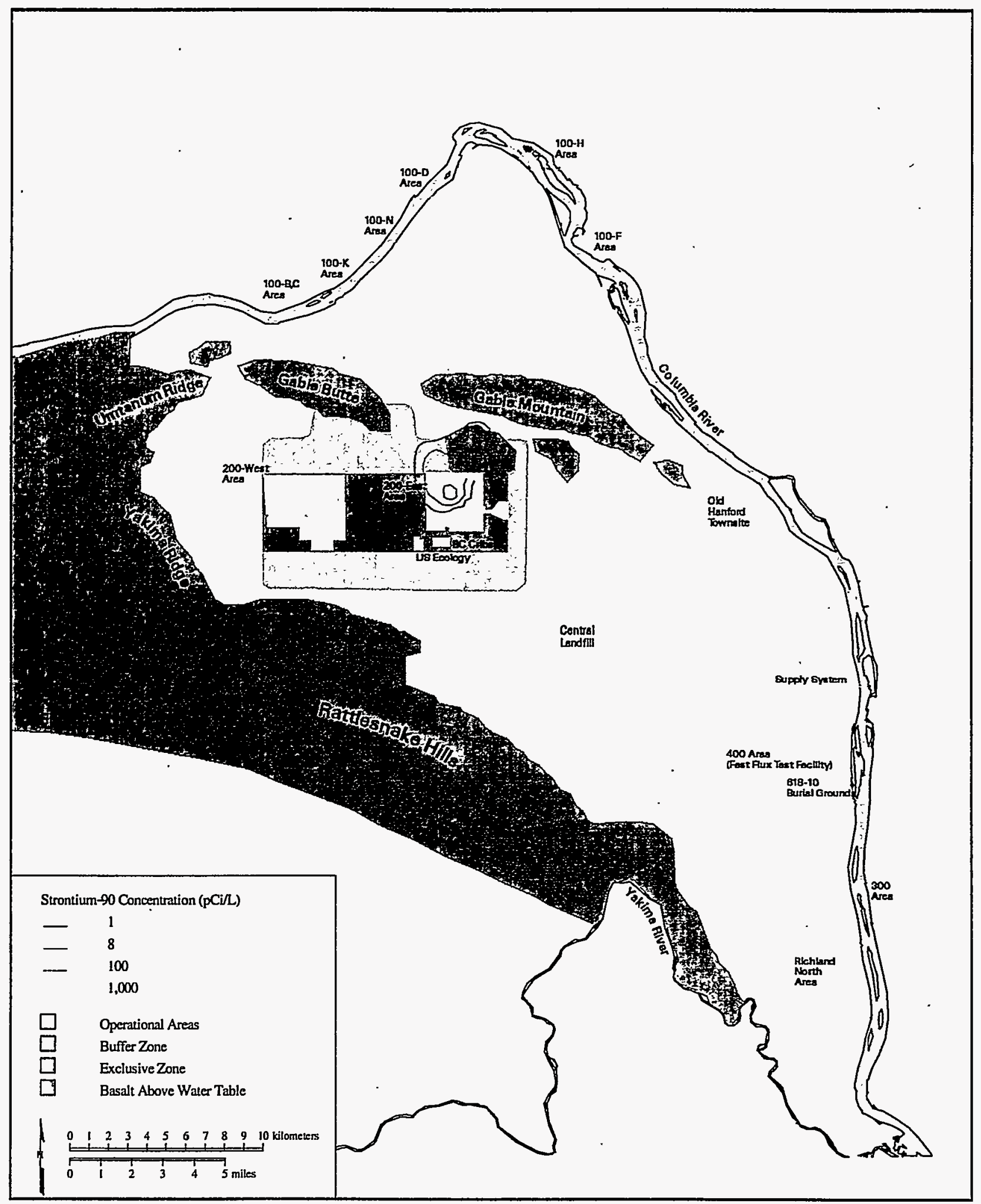

97skw055.eps December 31, 1997

Figure 5.27. Areal Distribution of Strontium-90 in 2049 as Predicted with the Three-Dimensional Model 


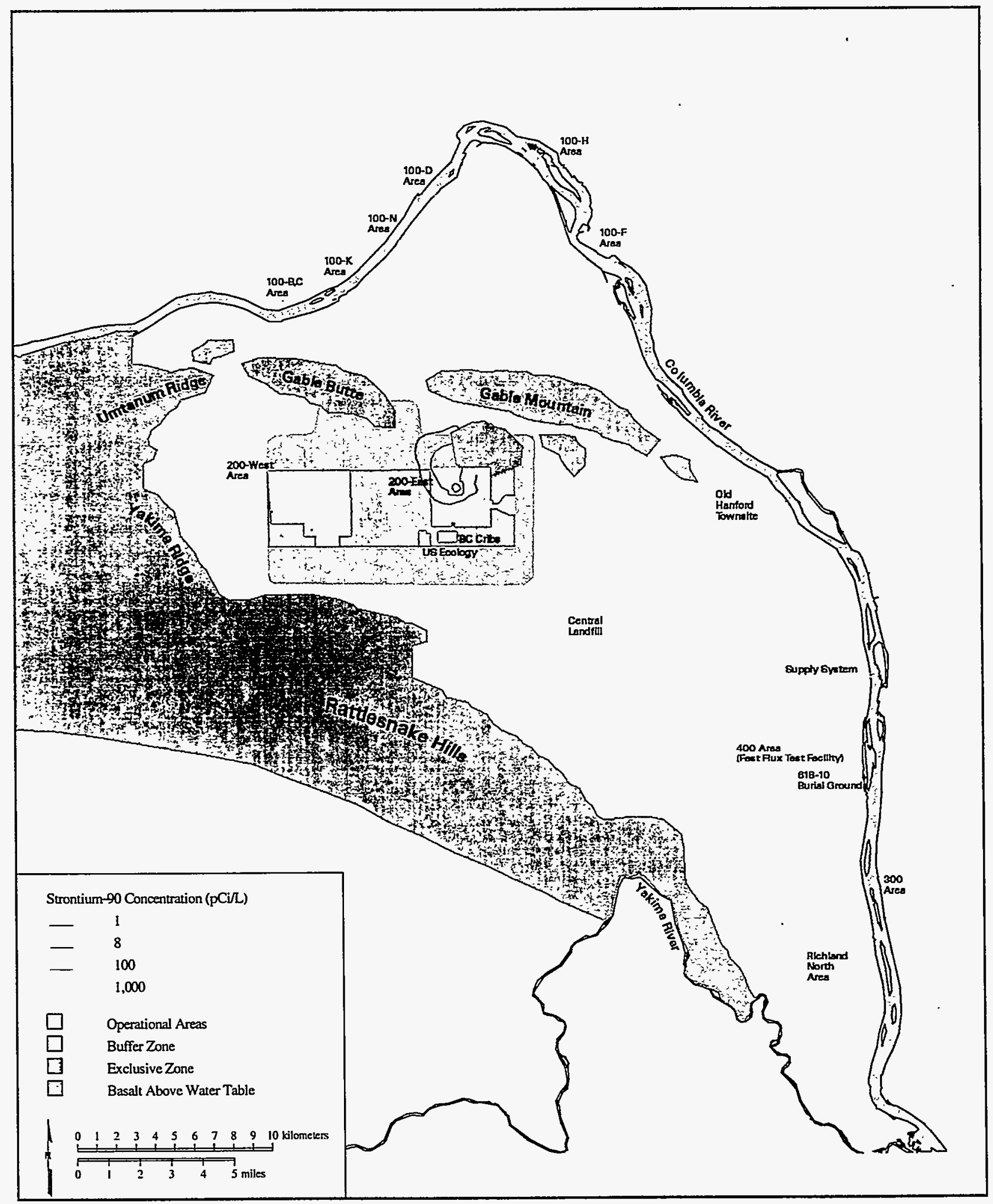

97skw056.eps December 31, 1997

Figure 5.28. Areal Distribution of Strontium-90 in 2099 as Predicted with the Three-Dimensional Model 


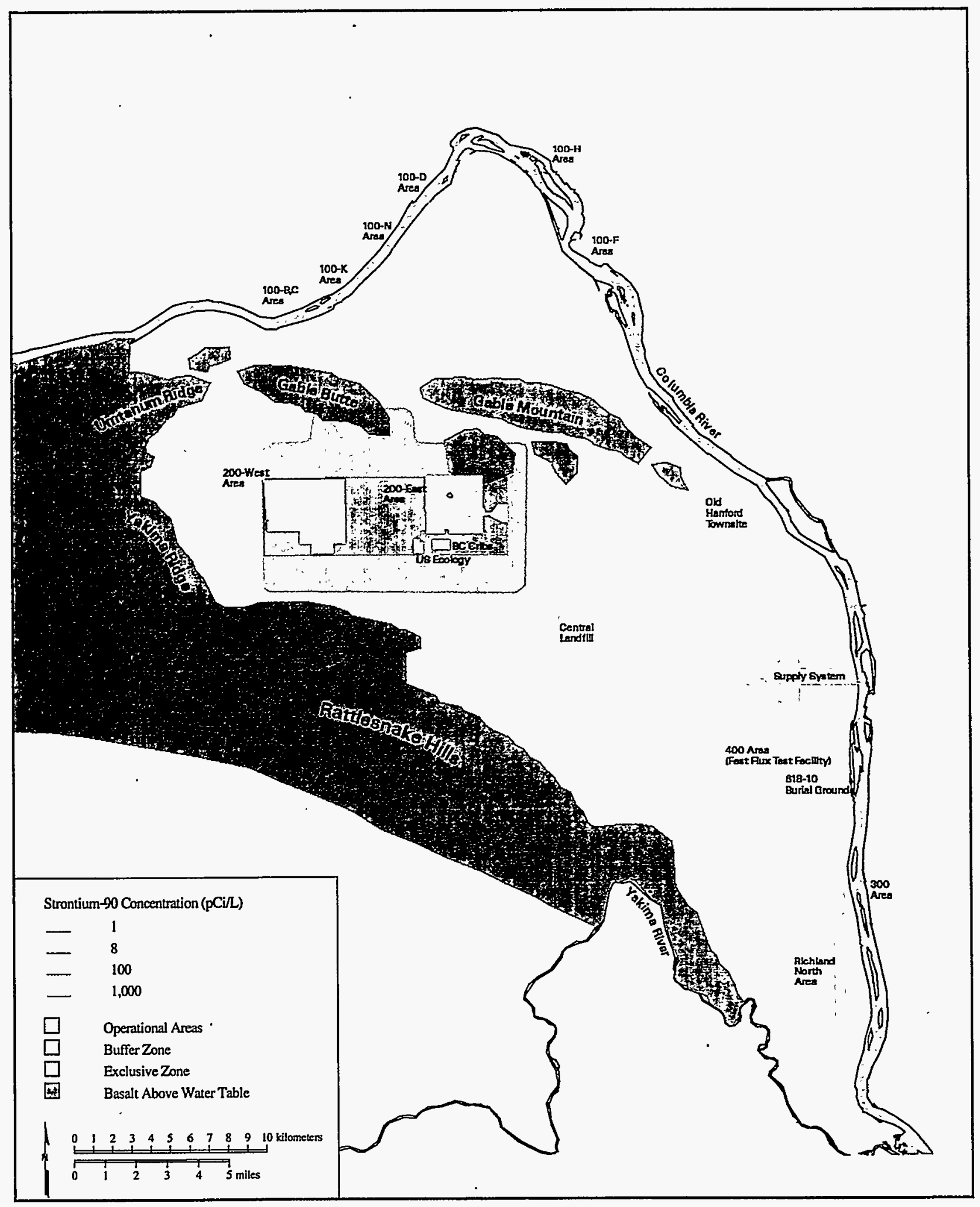

97skw057.eps December 31, 1997

Figure 5.29. Areal Distribution of Strontium- 90 in 2299 as Predicted with the Three-Dimensional Model 


\subsection{Summary and Conclusions}

The initial development, calibration, and initial application of a three-dimensional model of groundwater flow and contaminant transport are important first steps in developing a tool for evaluating the impacts of large-scale site plume transport. Such a tool can also be used to evaluate the effects of remediating Hanford Site groundwater and to design long-term monitoring strategies for the Site. The following summary and conclusions are based on the initial development and calibration of the threedimensional flow model for the Hanford Site and the examination of results of transport models for selected contaminant plumes.

\subsection{Current Modeling Results}

The three-dimensional flow and transport model is based on the CFEST code and is able to simulate the major aquifer features needed to assess large-scale plume migration and transport. The subregion modeling capability of CFEST allows flexibility for evaluating smaller-scale plumes and related phenomena.

Previous calibration efforts reported in Wurstner et al. (1995) were improved with recalibration of the two-dimensional model that considered constraints based on measured transmissivities. This twodimensional calibration, combined with knowledge of the three-dimensional hydrogeologic layers defined in the model, provides the technical basis for developing the three-dimensional model both by considering the previous two-dimensional calibration and the updated geologic and hydrologic conceptualization of the unconfined aquifer system.

The three-dimensional flow model provides good general agreement with 1979 conditions and reproduces the transient response of the aquifer reasonably well. Model simulations of projected reductions in artificial discharges at the Site showed that over about a 300-year period, the water table will decline significantly and return to near pre-Hanford water-table conditions estimated for 1944. Over this period, model results show that the water table will drop as much as about $11 \mathrm{~m}$ in the 200 -West Area and $10 \mathrm{~m}$ in the 200-East Area near B Pond. The model results compared favorably with overall water-table conditions estimated prior to Hanford operations in 1944, except in two areas: 1) the area west of the 200-Area plateau, where higher predicted hydraulic heads reflect boundary conditions that consider the effect of 
increased irrigation from areas upgradient of the modeled region; and 2) the area north of Richland, where the model considered the hydraulic effect of the North Richland well field.

Flow modeling results also suggest that as water levels drop in the vicinity of central areas in the model where the basalt crops out above the water table, the saturated thickness of the unconfined aquifer greatly decreases and the aquifer may actually dry out. This thinning/drying of the aquifer is predicted to occur in the area between Gable Butte and the outcrop south of Gable Mountain, resulting in the northern area of the unconfined aquifer becoming hydrologically separated from the area south of Gable Mountain and Gable Butte. Therefore, flow from the 200-West Area and the northern half of the 200-East Area, which currently migrates through the gap between Gable Butte and Gable Mountain, will be effectively cut off in the next 200 to 300 years. In time, the overall water table (including groundwater mounds near the 200-East and -West Areas) will decline, and groundwater movement from the 200-Area plateau will shift to a dominantly west-to-easterly pattern of flow toward points of discharge along the Columbia River between the Old Hanford townsite and the Washington Public Power Supply System facility.

Results of the three-dimensional transport modeling resulted in the following conclusions regarding specific contaminants:

- Model forecasts for the tritium plume originating from the 200 Area showed that the plume will migrate to points of discharge along the Columbia River between the Old Hanford townsite and an area north of the 300 Area over a period of about 90 to 100 years before it completely discharges into the river and/or decays below detection limits.

- Transport modeling of the iodine-129 plume indicated that the plume will migrate toward and discharge into the Columbia River after a period of about 600 years. Over the period of migration, iodine- 129 concentrations predicted to discharge into the river will decline slightly by the process of dispersion and sorption. However, initial concentrations will not fall significantly below current levels because of the radionuclide's long half-life. The iodine-129 plume from the 200-West Area is predicted to migrate toward the 200-East Area as it is reduced by dispersion and sorption.

- Transport modeling of the technetium-99 plume indicated that the current technetium-99 plumes will continue to slowly migrate laterally from source locations in the 200 Area to the Columbia River. The plumes in the 200-West Area decline to levels below regulatory concern as they 
migrate eastward toward the 200-East Area. The technetium-99 plume from the northern part of the 200-East.Area and migrating northward through the gap between Gable Butte and Gable Mountain will continue to migrate in this direction toward the Columbia River. However, concentration levels of the simulated plumes will decline to below DWS over a period of 100 years by the processes of plume dispersion and dilution related to infiltration.

- Transport modeling of the uranium plume indicated that because of the process of adsorption, the current uranium plumes in the 200-Area plateau will migrate very slowly from current source locations in the 200 Areas outside of the 200-Area exclusion and buffer zones.

- Transport modeling of the strontium-90 plume indicated that the current strontium-90 plume in the 200-East Area will likely migrate very little from its current location because strontium-90 tends to adsorb to Hanford sediments.

\subsection{Comparison of Past Site-Wide Modeling}

In general, the results of iodine-129, technetium-99, and uranium transport analyses with the threedimensional model are also in agreement with those of Chiaramonte et al. (1996). Both models predicted the same general movement and shape for each of the simulated plumes from source locations to points of discharge along the Columbia River.

For iodine-129 in particular, maximum concentrations in both models were found to discharge to the Columbia River in the vicinity of the Old Hanford townsite. However, as in the case of tritium, results of the three-dimensional model indicated

- higher estimates of peak concentrations for all contaminants at shallow depths and less vertical migration than reported in Chiaramonte et al. (1996), and

- higher concentration levels of iodine-129 in groundwater entering the Columbia River over a longer period of time.

For technetium-99, concentration levels in the technetium-99 plume declined below regulatory levels of concern before the plume moved out of the 200 -Area plateau. For uranium, transport results show the 
plume remains largely within the 200-Area plateau. The overall trends of technetium-99 and uranium transport resulting from this analysis were very consistent with technetium-99 and uranium simulation results done by Chiaramonte et al. (1996).

As in the case of tritium, these differences are attributable to differences in basic assumptions made about the hydrogeologic framework and the horizontal and vertical discretization used in each model. The differences in assumptions resulting from each modeling approach affect lateral and vertical distributions of predicted hydraulic heads and contaminant in the unconfined aquifer.

\subsection{Potential Impacts to Site Water Supplies}

Potential water-quality impacts were examined by evaluating predictions of tritium concentrations at drinking-water supply well locations on the Hanford Site (Figure 6.1). Two principal drinking water supplies are 1) main and auxiliary supply wells located at the Fast Flux Test Facility (FFTF) in the 400 Area (wells 499-S0-7, 499-S0-8, and 499-S1-8J), and 2) the City of Richland wells in the North Richland well field. Other drinking-water supplies of concern include one well at Yakima Barricade and two wells at the Washington Public Power Supply System (WPPSS) that are used as backup for a surfacewater supply (wells 699-13-1A and 699-13-1B). Other water-supply wells potentially impacted include 1) two wells at B Plant (299-E15 and 299-E28-11) and one well at the AY/AZ Tank farms (299-E26-6) currently being used for emergency cooling water in the 200-East Area, 2) one well at the Hanford Patrol

Training Center, and 3) one well being used for aquatic studies in the 300 Area (well 399-4-12). Following is a brief assessment of the impacts of tritium at all of these water-supply well systems at the Hanford Site.

400 Area Water Supply. The water supply for the 400 Area is provided by wells completed in the unconfined aquifer. Detection of tritium in the initial supply wells (499-S0-7 and 499-S0-8), which are completed near the top of the aquifer, led to the development of an additional well in the lower part of the aquifer in 1985 (well 499-S1-8J) to reduce tritium concentration levels to below the 4-mrem/yr effective dose equivalent standard. This deeper well is the primary supply well, and well 499-S0-7 is used as a backup supply. Well 499-S0-8 is maintained for emergency use.

Currently, the water supply wells at FFTF produce groundwater containing tritium concentrations ranging from 11,000 to $38,000 \mathrm{pCi} / \mathrm{L}$. Model results suggest that the shallow auxiliary wells at the FFTF will continue to be impacted by the tritium plume originating from the 200-East Area for the next 10 to 
20 years (Figures 6.2 and 6.3). Tritium levels at this location are expected to remain above the 20,000-pCi/L level until sometime before 2020 (Figure 6.4). After that time, tritium will continue to decline to below $500 \mathrm{pCi} / \mathrm{L}$ between the years 2070 and 2080 .

North Richland Well Field. Currently, tritium is detected in wells at the North Richland well field at levels essentially equivalent to those in the Columbia River at the Richland Pumphouse (Dirkes and Hanf 1996). Model results suggest that tritium concentrations now found in the 300 Area exceeding $2000 \mathrm{pCi} / \mathrm{L}$ will not reach the North Richland well field.

Water Supplies at WPPSS. Currently, backup water supply wells at WPPSS are sampled quarterly by the WPPSS personnel for selected radionuclides including tritium, and less frequently for nitrates and volatile organic compounds. Tritium is being detected at levels between 1000 and $2000 \mathrm{pCi} / \mathrm{L}$. Model results suggest that tritium levels at these well locations will potentially be above this level over the next 5 to 10 years as the tritium plume slowly migrates eastward. However, modeling results also suggest that tritium levels will decline to below $20,000 \mathrm{pCi} / \mathrm{L}$ sometime before 2020 (Figure 6.4) and will decline to well below $2000 \mathrm{pCi} / \mathrm{L}$ after about 60 to 70 years.

Water Supply at the Hanford Training Center. Currently, no tritium attributable to the plume originating from the 200-East Area has been measured in the water supply well at the Hanford Training Center. Model results suggest that tritium concentrations now found in the 300 Area exceeding $2000 \mathrm{pCi} / \mathrm{L}$ will not reach this supply well.

Water Supply in 300 Area. Currently, tritium attributable to the plume originating from the 200-East area has been measured in the water supply well in the 300 Area used for aquatic studies. Model results suggest that tritium concentrations now found in the 300 Area exceeding $3000 \mathrm{pCi} / \mathrm{L}$ will decline at this location over the next 10 to 20 years.

Water Supplies in the 200-East Area. Currently, the two wells at B Plant (299-E15 and 299-E28-11) and the one well at the AY/AZ Tank farms (299-E26-6) currently being used for emergency cooling water in the 200-East Area are being impacted by tritium. Tritium levels in the vicinity of B-Plant wells currently range from 12,000 to $20,000 \mathrm{pCi} / \mathrm{L}$. Model results suggest that tritium levels in B-Plant will likely remain at this level for the next several years but will decline below levels of concern within 10 to 20 years. Tritium levels in wells in the vicinity of the AY/AZ Tank farms currently range from about 3000 to 5000 
$\mathrm{pCi} / \mathrm{L}$. Model results suggest that tritium levels in the AY/AZ Tank farm area will likely remain at this level for the next 10 to 20 years.

Simulated levels of iodine-129 suggest that only water supplies in the 200-East Area could potentially be impacted. The two wells near B-Plant and the one well near the AX/AZ Tank farms currently contain iodine-129 levels below $1 \mathrm{pCi} / \mathrm{L}$, but wells near the $\mathrm{AX} / \mathrm{AZ}$ Tank farms could potentially produce higher levels of iodine as the current iodine-129 plume migrates eastward from the 200-East Area. Modelpredicted levels of iodine-129 shown in Figure 6.5 suggest that within 20 to 30 years, iodine levels in excess of $1 \mathrm{pCi} / \mathrm{L}$ currently in the 200-East Area would be found about halfway to the Columbia River by 2030. The iodine-129 plume in the 200 -West Area will be expected to migrate slowly toward the 200-East Area, but model results (Figure 6.5) suggest that levels exceeding $1 \mathrm{pCi} / \mathrm{L}$ would not reach the 200-East Area within 30 years.

Potential water-quality impacts projected by the three-dimensional model simulations of technetium-99, uranium, and strontium-99 were examined by evaluating predicted concentrations of these constituents at drinking-water supply well locations on the Hanford Site. None of the identified water supplies on the Site will be impacted by significant concentrations of any of these constituents. Levels of technetium-99, uranium, and strontium predicted for future conditions show no impact on identified water supplies in the 200-East Area near B plant and the AY/AZ Tank farm area. 


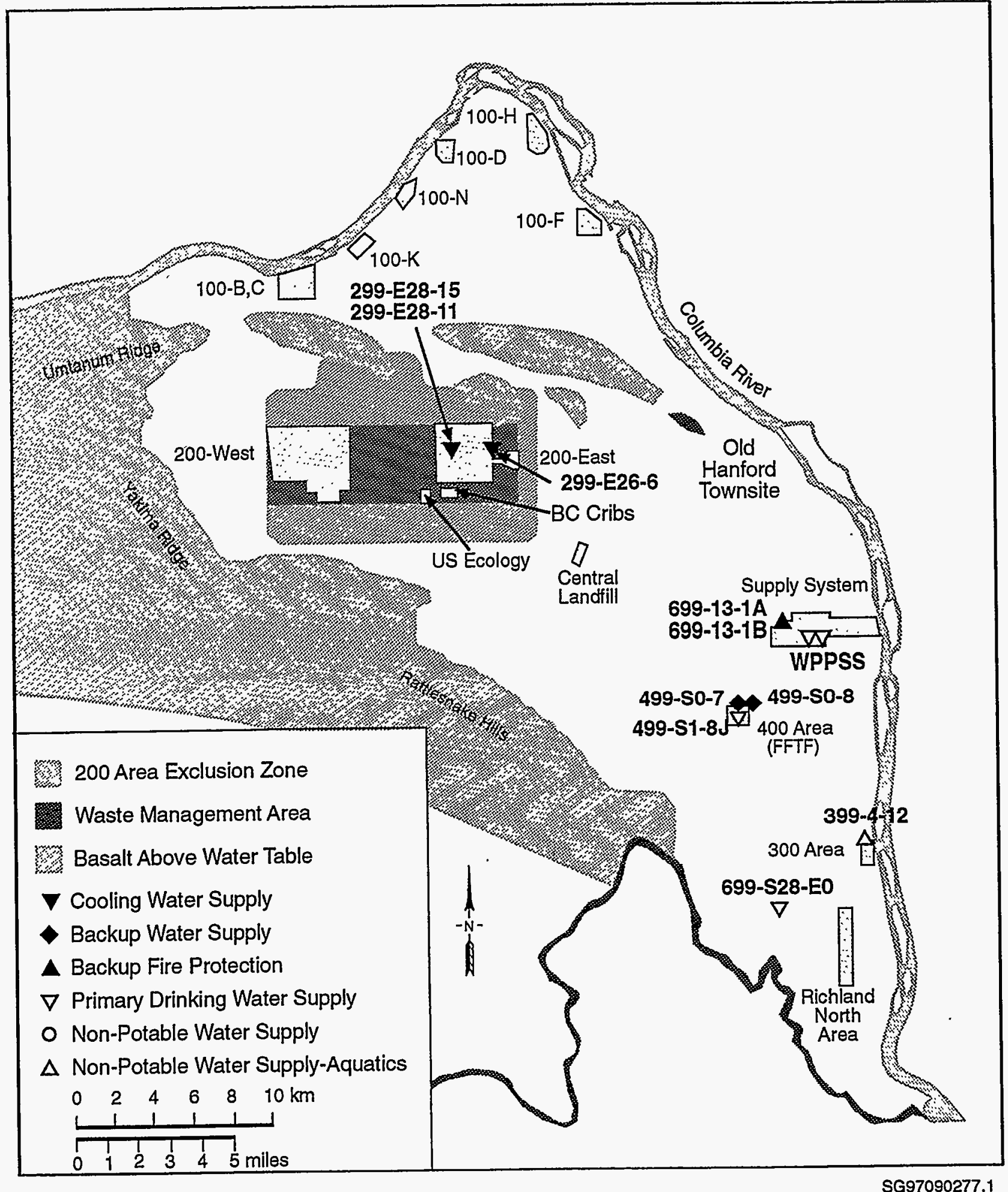

Figure 6.1. Hanford Site Water-Supply Wells 

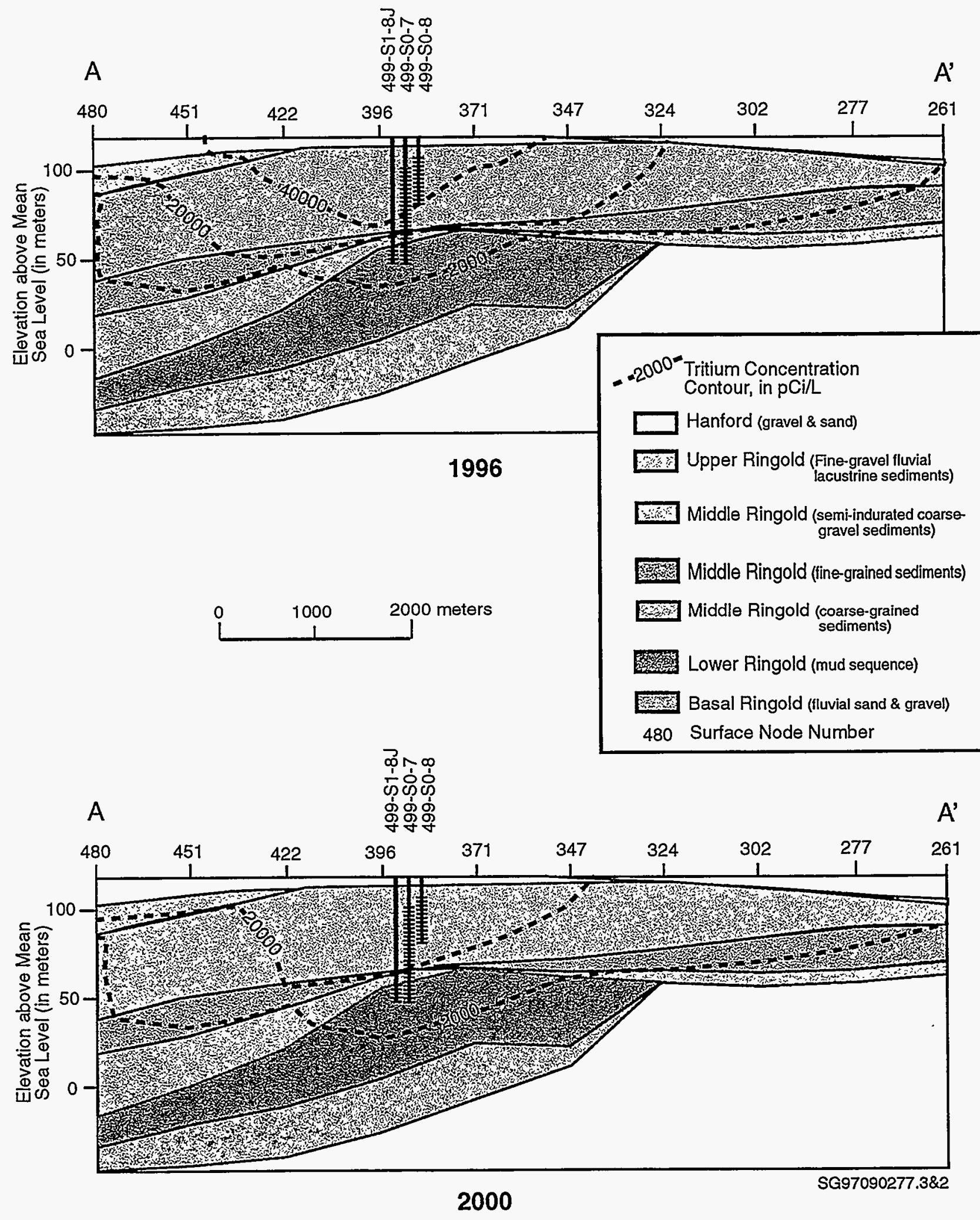

Figure 6.2. Northwest-to-Southeast Cross Section Through the 400 Area Showing Major Hydrogeologic Units, the Location of Drinking-Water Supply Wells, and Predicted Levels of Tritium for Conditions 1996 and 2000 


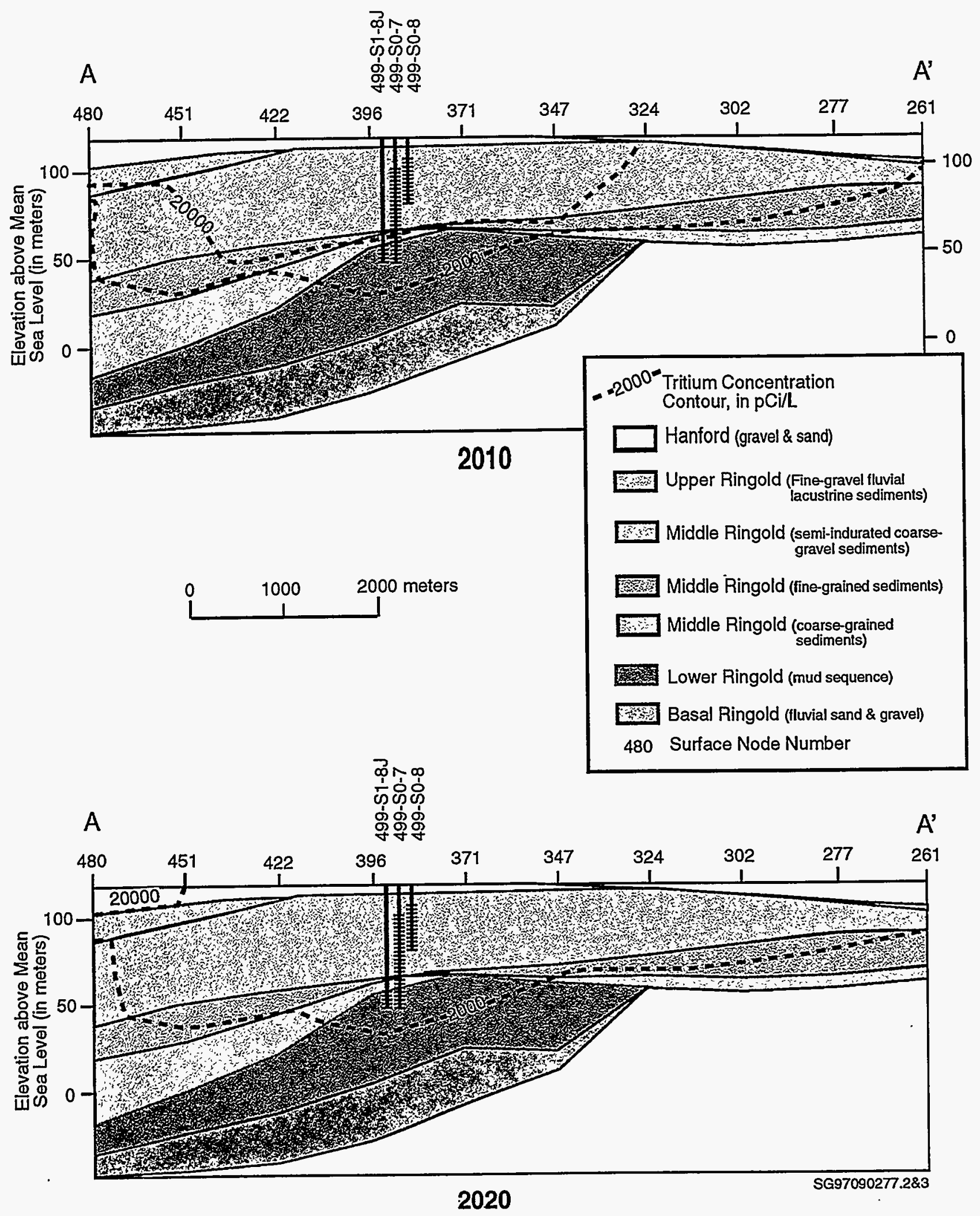

Figure 6.3. Northwest-to-Southeast Cross Section Through the 400 Area Showing Major Hydrogeologic Units, the Location of Drinking-Water Supply Wells, and Predicted Levels of Tritium for Conditions 2010 and 2020 


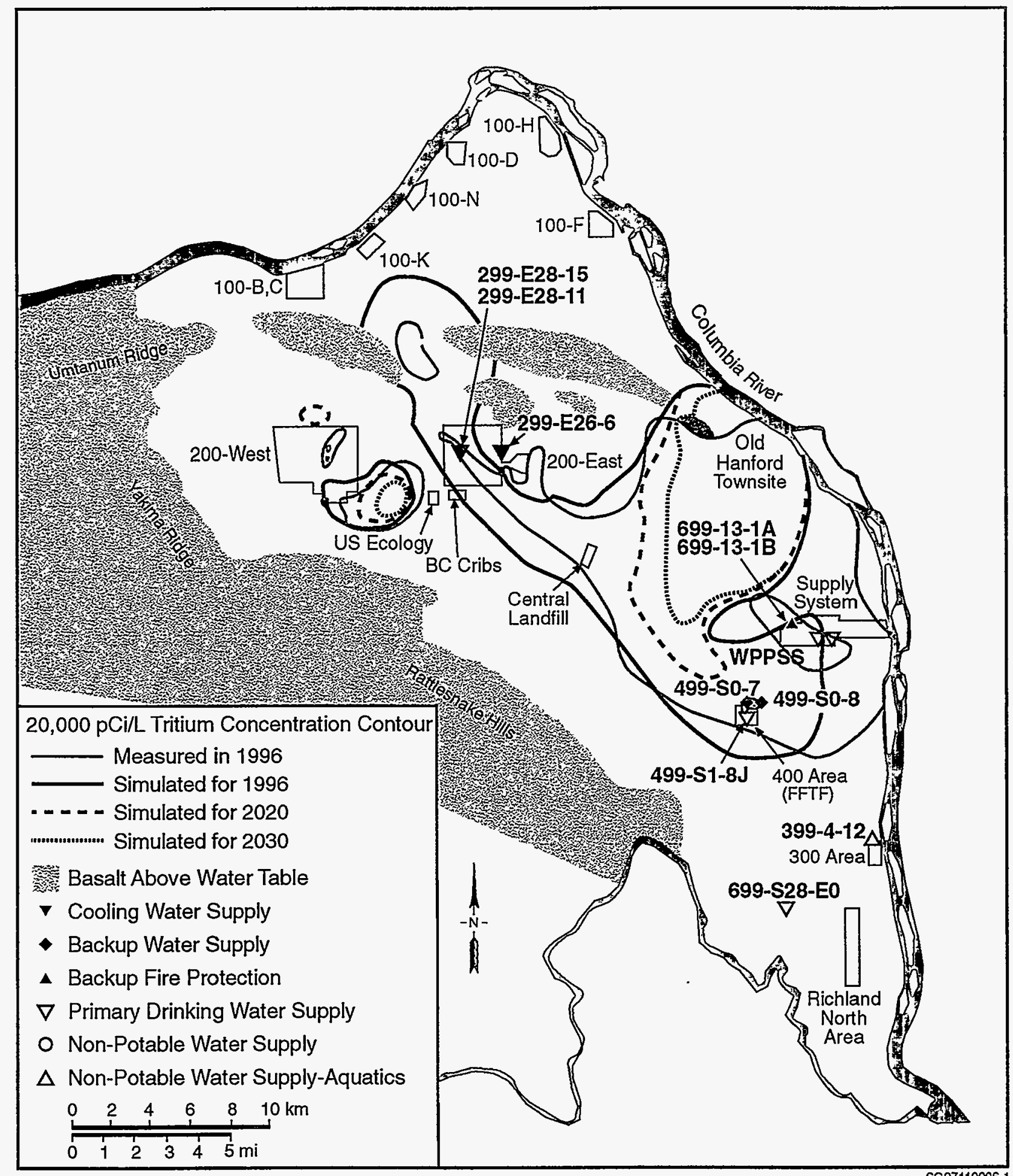

SG97110006.

Figure 6.4. Simulated Position of $20,000 \mathrm{pCi} / \mathrm{L}$ Tritium Contour for 1996, 2020, and 2030 


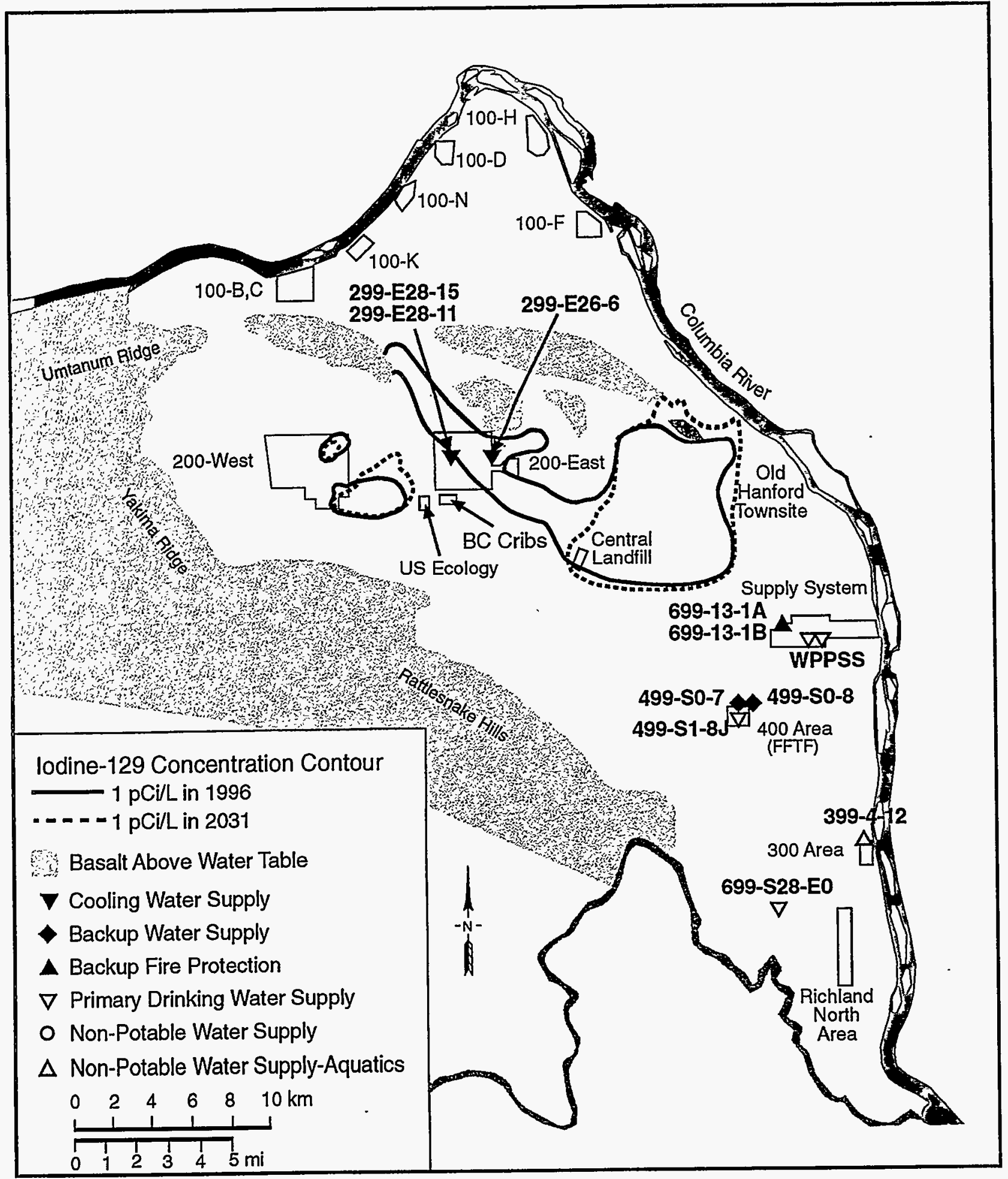

SG97090277.12

Figure 6.5. Simulated Position of $1 \mathrm{pCi} / \mathrm{L}$ Iodine-129 Contour for 1996 and 2031 


\subsection{References}

Barnett, D. B., M. D. Freshley, M. P. Bergeron, S. K. Wurstner, and C. R. Cole. 1997. Tritium Monitoring in Groundwater and Evaluation of Model Predictions for the Hanford Site 200 Area Effluent Treatment Facility. PNNL-11665, Pacific National Northwest Laboratory, Richland, Washington.

Biershenck, W. H. 1957. Fluctuations of Hanford Water Levels. HW-53599, Richland, Washington.

Cearlock, D. B., K. L. Kipp, and D. R. Friedrichs. 1975. The Transmissivity Iterative Calculation Routine - Theory and Numerical Implementation. BNWL-1706, Pacific Northwest Laboratory, Richland, Washington.

Chiaramonte, G. R. C. W. Denslow, A. J. Knepp, R. D. Landon, and S. Panday. 1996. Hanford Site-Wide Groundwater Remediation Strategy - Groundwater Contaminant Predictions. BHI-00469, Bechtel Hanford, Inc., Richland, Washington.

Cole, C. R, S. B. Yabusaki, and C. T. Kincaid. 1988. CFEST-SC: Coupled Fluid, Energy, and Solute Transport Code, Super Computer Version, Documentation, and User's Manual. Battelle Pacific Northwest Laboratories, Richland, Washington.

Connelly, M. P., B. H. Ford, and J. W. Lindberg. 1992a. Hydrogeologic Model for the 200 East Groundwater Aggregate Area. WHC-SD-EN-TI-019, Westinghouse Hanford Company, Richland, Washington.

Connelly, M. P., B. H. Ford, and J. V. Borghese. 1992b. Hydrageologic Model for the 200 West Groundwater Aggregate Area. WHC-SD-EN-TI-014, Westinghouse Hanford Company, Richland, Washington.

Dirkes, R. L., and R. W. Hanf, editors. 1996. Hanford Site Environmental Report for Calendar Year 1995. PNNL-11139, Pacific Northwest Laboratory, Richland, Washington.

Eddy, P. A., and J. S. Wilbur. 1980. Environmental Monitoring Report on Radiological Status of the Groundwater Beneath the Hanford Site, January - December 1979. PNL-3346, Pacific Northwest Laboratory, Richland, Washington.

Eddy, P. A., D. A. Myers, and J. R. Raymond. 1978. Vertical Contamination in the Unconfined Groundwater at the Hanford Site, Washington. PNL-2724, Pacific Northwest Laboratory, Richland, Washington.

Fayer, M. J., and T. B. Walters. 1995. Estimated Recharge Rates at the Hanford Site. PNL-10285, Pacific Northwest Laboratory, Richland, Washington.

Foley, M. G., D. J. Bradley, C. R. Cole, J. P. Hanson; K. A. Hoover, W. A. Perkins, and M. D. Williams. 1995. Hydrogeology of the West Siberian Basin and Tomsk Region. PNL-10585, Pacific Northwest Laboratory, Richland, Washington.

Gupta, S. K. 1997. Draft User's Manual, CFEST96 Flow and Solute Transport, Constant/Variable Density, Computationally Efficient, and Low Disk PC/Unix Version. Consultant for Environmental System Technologies, Irvine, California. 
Gupta, S. K., C. R. Cole, C. T. Kincaid, and A. M. Monti. 1987. Coupled Fluid, Energy, and Solute Transport (CFEST) Model: Formulation and User's Manual. BMI/ONWI-660, Battelle Memorial Institute, Columbus, Ohio.

Hartman, M. J., and P. E. Dresel, editors. 1997. Hanford Site Groundwater Monitoring for Fiscal Year 1996. PNNL-11470, Pacific Northwest National Laboratory, Richland, Washington.

Jacobson, E. A., and M. D. Freshley. 1990. An Initial Inverse Calibration of the Groundwater Flow Model for the Hanford Unconfined Aquifer. PNL-7144, Pacific Northwest Laboratory, Richland, Washington.

Kaplan, D. J. and R. J. Serne. 1995. Distribution Coefficient Values Describing Iodine, Neptunium, Selenium, Technetium, and Uranium Sorption to Hanford Sediments. PNL-10379, SUP. 1, Pacific Northwest Laboratory, Richland, Washington

Kaplan, D. I., R. J. Serne, A. T. Owen, J. Conca, T. W. Wietsma, and T. L. Gervais. 1996. Radionuclide Adsorption Distribution Coefficients Measured in Hanford Sediments for the Low-Level Waste Performance Assessment Project. PNNL-11385, Pacific Northwest National Laboratory, Richland, Washington.

Khaleel, R, and E. J. Freeman. 1995. Vanability and Scaling of Hydraulic Properties for 200 Area Soils, Hanford Site. WHC-EP-0883, Westinghouse Hanford Company, Richland, Washington.

Kipp, K. L. and R. D. Mudd. 1974. Selected Water-Table Contour Maps and Well Hydrographs for the Hanford Reservation, 1944-1973. BNWL-B-360, Battelle Pacific Northwest Laboratories, Richland, Washington.

Kipp, K. L., A. E. Reisenauer, C. R. Cole, and L. A. Bryan. 1972. Variable Thickness Transient Groundwater Flow Model: Theory and Numerical Implementation. BNWL-1709, Pacific Northwest Laboratory, Richland, Washington.

Law, A., S. Panday, C. Denslow, K. Fecht, and A. Knepp. 1996. Hanford Site-wide Groundwater Flow and Transport Model Calibration Report. BHI-00608, Bechtel Hanford, Inc., Richland, Washington.

Nelson, J. L. 1959. Soil Column Studies with Radiostrontium. Effects of Temperature and of Species of Accompanying Ion. HW-62035, General Electric Company, Richland, Washington.

Newcomb, R. C, J. R. Strand, and F. J. Frank. 1972. Geology and Groundwater Characteristics of the Hanford Reservation of the U.S. Atomic Energy Commission. U.S. Geological Survey Professional Paper 717, U.S. Geological Survey, Washington, D.C.

Rhodes, D. W. 1956. Adsorption by Soil of Strontium from 216-S Crib Waste. HW-42699, General Electric Company, Richland, Washington.

Routson, R. C., G. S. Barney, and R. O. Seil. 1978. "Measurement of Fission Product Sorption Parameters for Hanford 200 Area Sediment Types. Progress Report." RHO-LD-73. Rockwell Hanford Operations, Richland Washington. 
Serne, R. J., J. L. Conca, V. L. LeGore, K. J. Cantrell, C. W. Lindenmeier, J. A. Campbell, J. E. Amonette, and M. I. Wood. 1993. Solid-Waste Leach Characteristics and Contaminant-Sediment Interactions. Volume 1: Batch Leach and Adsorption Tests and Sediment Characterization. PNL-8889, Vol 1, Pacific Northwest Laboratory, Richland, Washington.

Thorne, P. D., and M. A. Chamness. 1992. Status Report on the Development of a Three-Dimensional Conceptual Model for the Hanford Site Unconfined Aquifer System. PNL-8332, Pacific Northwest Laboratory, Richland, Washington.

Thorne, P. D., and D. R. Newcomer. 1992. Summary and Evaluation of Available Hydraulic Property - Data for the Hanford Site Unconfined Aquifer System. PNL-8337, Pacific Northwest Laboratory, Richland, Washington.

Thorne, P. D., M. A. Chamness, F. A. Spane Jr., V. R. Vermeul, and W. D. Webber. 1993. ThreeDimensional Conceptual Model for the Hanford Site Unconfined Aquifer System, FY 93 Status Report. PNL-8971, Pacific Northwest Laboratory, Richland, Washington.

Thome, P. D., M. A. Chamness, V. R. Vermeul, Q. C. MacDonald, and S. E. Schubert. 1994. ThreeDimensional Conceptual Model for the Hanford Site Unconfined Aquifer System, FY 1994 Status Report. PNL-10195, Pacific Northwest Laboratory, Richland, Washington.

U.S. Department of Energy (DOE). 1988. Consultation Draft, Site Characterization Plan, Reference Repository Location, Hanford Site, Washington. DOE/RW-0164, 2 Vol., Richland, Washington.

Walters, W. H., M. C. Richmond, and B. G. Gilmore. 1994. Reconstruction of Radionuclide Concentrations in the Columbia River from Hanford, Washington to Portland, Oregon, January 1950 : January 1971. BNWD-2225 HEDR, Battelle Pacific Northwest Division, Richland, Washington.

Wurstner, S. K., and J. L. Devary. 1993. Hanford Site Groundwater Model: Geographic Information System Linkages and Model Enhancements, FY 1993. PNL-8991, Pacific Northwest Laboratory, Richland, Washington.

Wurstner, S. K., P. D. Thorne, M. A. Chamness, M. D. Freshley, and M. D. Williams. 1995. Development of a Three-Dimensional Groundwater Model of the Hanford Site Unconfined Aquifer System: FY 1995 Status Report. PNL-10886, Pacific Northwest Laboratory, Richland, Washington. 


\section{Appendix}

Artificial Recharge Volumes and Source Concentrations for Transient-Flow and Transport Models 


\section{Appendix}

\section{Artificial Recharge Volumes and Source Concentrations for Transient-Flow and Transport Models}

This appendix lists the artificial recharge volumes and spring discharges used as input for the transient-flow models (both two- and three-dimensional). The volumes are summarized in Table A.1 and the concentration inputs are summarized in Table A.2. The volumes and concentrations for the transient models are assigned as annual averages. 
Table A.1.Annual Average Discharge Volumes $\left(\mathrm{m}^{3 /} \mathrm{d}\right)$ Input to the Two- and Three-Dimensional Transient-flow Models

\begin{tabular}{|c|c|c|c|c|c|c|c|c|c|c|c|c|c|c|c|c|c|c|c|c|c|c|}
\hline & & 1980 & 1981 & 1982 & 1083] & 1984] & 1985 & 1986 & DD87 & 1988 & 1980 & 1990 & 1991 & 1992 & (993) & [994] & 1995: & 1996 & 1997] & 1998] & 2016 & 2026] \\
\hline DESCRIPTION or Disposal/DATE Ocar & Nod & 1980 & 1981 & 1982 & 1983 & 1984 & 1983 & 1986 & 1987 & 1988 & 1989 & 1990 & क्शा & 1992 & 1993 & 1994 & 1925: & 1996 & 1997 & 1098 & 2016 & 2026 \\
\hline $100 B$ Seplic Tank & 90 & & 1.00 & & & 2.00 & 1.00 & & & & & & & & & & & & & & & \\
\hline $100 \mathrm{D}$ Seplic Tank, 120.D-1 & 806 & 38.00 & 40.00 & 36.00 & 39.00 & 39.00 & 40.00 & 40.00 & 4000 & 33.00 & 33.00 & 33.00 & 33.00 & 33.00 & 36.00 & 15.00 & & & & & & \\
\hline 100 Seplic Tanik & 33 & & & & 2.00 & 2.00 & 3.00 & 2.00 & 1.00 & & & & & & & & & & & & & \\
\hline 10011 Scppic Tanks & 801 & & & & & & & & & & 1,00 & 1.00 & 1.00 & & & & & & & & & \\
\hline $1301 \cdot \mathrm{N}$ and $1325 \cdot \mathrm{N}$ & 16 & 12417.00 & 10083.00 & 10083.00 & 9183.00 & 10450.00 & 9983.00 & 7223.00 & 2767.00 & 1650.00 & 1742.00 & 1108.00 & & & & & & & & & & \\
\hline 1324-NA and 130-N-1 & 20 & 43.00 & 43.00 & 43.00 & 43.00 & 43.00 & 43.00 & 43.00 & 43.00 & 43.00 & 43.00 & 11,00 & & & & & & & & & & \\
\hline $2101 \cdot \mathrm{M}$ & 334 & 14,000 & 15.00 & 10.00 & 13,00 & 23.00 & 17.00 & 13.00 & 9.00 & 13.00 & 15.00 & 15.00 & 15,00 & 14.00 & 15.00 & 15.00 & & & & & & \\
\hline $216-\Lambda-10$ and $216-\Lambda \cdot 45$ & 34 & & & 41.00 & III.00 & 414.00 & 483.00 & 357.00 & 216.00 & 136.00 & 25.00 & & & & & & & & & & & \\
\hline $216 \cdot A-23$ & 793 & 27158.00 & 16897.00 & 18875.00 & 40533.00 & 64067.00 & 31917.00 & & & & & & & & & & & & & & & \\
\hline $216 \cdot A \cdot 3$ & 323] & & & & & & & & & & & & & & & & & & & & & \\
\hline $216-A-30$ and $216-A-37-2$ & 3337 & 312.00 & 444.00 & 317.00 & 651.00 & 1333.00 & 2086.00 & 2234.00 & 1691.00 & 1150.00 & 1453.00 & 924.00 & 737.00 & & & & & & & & & \\
\hline $216 \cdot A \cdot 8$ & 310 & & & & & 3.00 & 1.00 & & & & & & & & & & & & & & & \\
\hline $216 \cdot \mathrm{B} \cdot 3$ & 316 & 12047.00 & 16725.00 & 14158.00 & 19292.00 & 14550.00 & 14542.00 & 62433.00 & 53867.00 & 72973.00 & 40375.00 & 27958.00 & 25133,00 & 21333.00 & 17917.00 & 19167.00 & 18164.00 & 19167.00 & & & & \\
\hline 216.B.55 and 224.B Steam Condensor & 302 & 154,00 & 161.00 & 90.00 & 170.00 & 112.00 & 33.00 & 22.00 & & 7.00 & 2.00 & & & & & & & & & & & \\
\hline $216 \cdot \mathbf{B} \cdot 63$ & 290 & 889.00 & 977.00 & 860.00 & 851.00 & 826.00 & 852.00 & 1415.00 & 960.00 & 790.00 & 1046.00 & 640.00 & 754.00 & 140.00 & & & & & & & & \\
\hline $216 . C-7$ and $200 \mathrm{E}$ Pollierhouse & 315 & & & & & & & & & & & & & & & & & & & & & \\
\hline 216.5 .25 and 216.0 .10 & 381 & 9829.00 & 3187.00 & 1363.00 & 965.00 & 3237.00 & 86.00 & & & & & & & & & & & & & & & \\
\hline 216.5 .26 and 291.5 Steam Condensor & 382 & & & & & 32.00 & 123.00 & 113,00 & 94.00 & 52.00 & 36.00 & 38.00 & 24.00 & 45.00 & 18.00 & 17.00 & 6.00 & & & & & \\
\hline $216 \cdot T-1$ & 278 & 33.00 & 33.00 & 33.00 & 33.00 & 33.00 & 33.00 & 33.00 & 33.00 & 33.00 & 33.00 & 32.00 & 29.00 & 29.00 & 28.00 & 28.00 & 10.00 & & & & & \\
\hline $216 \cdot T-4 \cdot 2$ & 294 & 53.00 & 53.00 & 53.00 & 53.00 & 53.00 & 33.00 & 33.00 & 53.00 & 53.00 & 53.00 & 53.00 & 33.00 & 33.00 & 52.00 & 32.00 & 19.00 & & & & & \\
\hline $216 \cdot U \cdot 12$ and $216 \cdot$ U. 17 & 352 & & & 1.00 & 3.00 & 15.00 & 13.00 & 11.00 & 2.00 & 2.00 & 4.00 & & & 3.00 & 6.00 & 1.00 & & & & & & \\
\hline $216 . \mathrm{U} \cdot 14 \mathrm{and} 216 \cdot \mathrm{U} \cdot 16$ & 363 & & & & & 780.00 & 1500.00 & 1486.00 & 982.00 & 785.00 & 1050.00 & 629.00 & 882.00 & 764.00 & 747.00 & 317.00 & & & & & & \\
\hline $216-\mathrm{W}-\mathrm{L}$ C and $2724-\mathrm{WB}$ Heater & 319 & & 123.00 & 490.00 & 1074.00 & 236.00 & 198.00 & 122.00 & 166.00 & 38.00 & 65.00 & 81.00 & 108.00 & 75.00 & 73.00 & & & & & & & \\
\hline $216-2-20$ & 346 & & 300.00 & 1038.00 & 1445.00 & 1897.00 & 1061.00 & 814,00 & 961.00 & 601.00 & 688.00 & 828.00 & 743.00 & 246.00 & 274.00 & 79.00 & 19.00 & & & & & \\
\hline 284-WB and 200W Powerhouse & 313 & & & & & 143.00 & 431.00 & 431.00 & 431.00 & 430.00 & 431.00 & 431.00 & 431,00 & 430,00 & 423.00 & 423.00 & 169.00 & & & & & \\
\hline $4608 \mathrm{~B} / \mathrm{C}$ and 400 Area Sanaitany Sencr & 570 & -325.00 & -327.00 & -327.00 & .327 .00 & -359.00 & -360.00 & .360 .00 & .360 .00 & -359.00 & -360.00 & .360 .00 & -360.00 & .359 .00 & -339.00 & $-339,00$ & -361.00 & & & & & \\
\hline W049.H(TEDF) & 321 & & & & & & & & & & & & & & & & 2045.00 & 2045.00 & 3409.00 & 3409900 & 3409.00 & \\
\hline WPPSS Sanliary Wassie Treatment F & 356 & & & & & & & & & & & & & & & & & & & & & \\
\hline $100 K$ Septic Tanks & 42 & 4.00 & 2.00 & 3.00 & 13.00 & 13.00 & 11.00 & 13.00 & 13.00 & 14.00 & 15.00 & 8.00 & 7.00 & 11.00 & 12.00 & 12.00 & 30,00 & & & & & \\
\hline 300 Area Ash Disposal and 300 Area Sani & \begin{tabular}{|c|}
762 \\
762 \\
\end{tabular} & 366.00 & 368.00 & 368.00 & 368.00 & 366.00 & 368.00 & 368.00 & 314.00 & 366.00 & 367.00 & 367.00 & 367.00 & 366.00 & 366.00 & 366.00 & 360.00 & & & & & \\
\hline 300 Areas Process Trenches & 763 & 8650.00 & 8783.00 & 8783.00 & 9458.00 & 9642.00 & 9817.00 & 9083.00 & 8942.00 & 4458.00 & 5083.00 & 5417.00 & 3347.00 & 1526.00 & 1153.00 & 800.00 & 800.00 & & & & & \\
\hline North Richliand Well Ficld & 735 & 16898.00 & 17772.00 & 11007.00 & 13140.00 & 22943.00 & 20157.00 & 19374.00 & 14813.00 & 10009.00 & 18242.00 & 12989,00 & 14056.00 & 7070,00 & 29465.00 & 29465.00 & 29465.00 & 29465.00 & 29465.00 & 29465.00 & 29465.00 & 29465.00 \\
\hline $124 \cdot \mathrm{N} \cdot 10$ & 25 & 71.00 & 88.00 & 100.00 & 121.00 & 124.00 & 155.00 & 153.00 & 155.00 & 98,00 & 60.00 & 49.00 & 39.00 & 33.00 & 72.00 & 72.00 & 33.00 & & & & & \\
\hline $216.5=10$ & 392 & 503.00 & 544.00 & 544,00 & 546.00 & 546.00 & 353.00 & 345.00 & 545.00 & 575.00 & 399.00 & 546.00 & 320.00 & & & & & & & & & \\
\hline $216 \cdot$ S. 19 & 406 & 141.00 & 235.00 & 125.00 & 177.00 & 97.00 & & & & & & & & & & & & & & & & \\
\hline $216 \cdot 2 \cdot 21$ & 333 & & & & & & & & & & & & & & & & & & & & & \\
\hline $\mathrm{CO} 018.1 \mathrm{H}$ & 256 & & & & & & & & & & & & & & & & & 93.00 & 321.00 & 31.00 & & \\
\hline $1199.33 .18 \mathrm{~B}$ & 756 & -299.00 & -300.00 & .300 .00 & -239.00 & & & $-1031,00$ & .617 .00 & -194.00 & .48 .00 & -29.00 & -149.00 & -191.00 & -738.00 & & & & & & & \\
\hline $1199-34-15 \mathrm{~A}$ & 698 & & & & & & & & & & & & & & & & & & & & & \\
\hline $699.0 \mathrm{RV}-1$ & 676 & .164 .00 & -164.00 & .164 .00 & .165 .00 & .279 .00 & -178.00 & .222 .00 & .73 .00 & -111.00 & -94.00 & .127 .00 & -999.00 & .233 .00 & -123.00 & & & & & & & \\
\hline $1199.16 \cdot 13 \mathrm{D}$ & 733 & -3284.00 & .3291 .00 & .3291 .00 & -3110.00 & -4182.00 & .4298.00 & -3053.00 & .2752 .00 & 66618.00 & -2101.00 & .2623 .00 & .4372 .00 & .2876 .00 & & & & & & & & \\
\hline Retllesnake Men Springs & 635 & 45.00 & 45.00 & 45.00 & 45.00 & 45.00 & 45.00 & 45,00 & 45.00 & 45.00 & 45.00 & 45.00 & 45.00 & 45.00 & 45.00 & 45.00 & 45,00 & 45.00 & 45.00 & 45.00 & 45.00 & 45.00 \\
\hline Ralllesnsko Min Springs & 631 & 91.00 & 91.00 & 91.00 & 91.00 & 91.00 & 91.00 & 91.00 & 91.00 & 91.00 & 91.00 & 91.00 & 91.00 & 91.00 & 91,00 & 91.00 & 91.00 & 91.0 & 91.00 & 91. & 91.00 & 91.00 \\
\hline Ratllesnate Men Springs & 621 & 91.00 & 91,00 & 91.00 & 91.00 & 91.0 & 91.00 & 91.00 & 91.00 & 91.00 & 92.00 & 91.00 & 91 & 91.00 & 91.00 & 91.00 & 91,6 & 91. & 91. & 91. & 91 & Tा \\
\hline Ratllesnake Mtn Springs & 607 & 182 & 182.00 & 182.00 & 18 & 182 & 182. & 182.00 & 182. & 182.00 & 182 & 182 & 182 & 182.00 & 182.00 & 182.00 & 182.1 & 182. & 182 & 182,00 & 182.00 & 182. \\
\hline Rallicsnato Mtn Springs & 600 & 182.00 & & 182.00 & & & 182.00 & 182.00 & 182.00 & 182.00 & & 182.00 & 182 & 182. & 182.000 & $182.00 \mathrm{O}$ & 182.00 & 182.00 & 182.00 & 182.00 & 182.00 & 182.00 \\
\hline Rallessnake Min Springs & 592 & 182.00 & 182.00 & 182.00 & 182.00 & 182.00 & 182.00 & 182.00 & 182.00 & 182.00 & 182.00 & 182.00 & 182.00 & 182.00 & 182.00 & 182.00 & 182.00 & 182.00 & 182.00 & 182.00 & 182.00 & 182.00 \\
\hline Retllesnato Mon Springs & 585 & 140.00 & 140.00 & 140.00 & 140.00 & 140.00 & 140.00 & 140.00 & 140.00 & 140.00 & 140.00 & 140.00 & 440.00 & 140.00 & 140.00 & 140.00 & 140.00 & 140.00 & 140.00 & 140.00 & 140.00 & 140.00 \\
\hline Rantlesnahe Men Springs & $\mid 579$ & 140.00t & 140.00 & 140,00 & 140.00 & 140.00 & $140.00 \mid$ & 140.001 & 140,00 & 140.00 & 140.00 & 140.00 & 140.00 & 140.00 & 140.00 & 140.00 & 140.00 & 140.00 & 140.00 & 140.00 & 140.000 & 140.00 \\
\hline Rontlesnako Men Springs & 566 & 1600 & 16000 & 140 & 140,000 & 160 & 140.00 & 140 & & 140 & 140 & 140, & 140.0 & 140 & & 140 & 140 & 140 & 140 & 140 & 140.00 & 110 \\
\hline Ratlessashe Min Springs & 5sil & 140.00 & 110.00 & 140.00 & 140.00 & 140.00 & 140.00 & $140,00[$ & 140.00 & 140.000 & 140.00 & 140.00 & 140.00 & 140.00 & 140.00 & 140.00 & 140.00 & 140.00 & 140.00 & 140.00 & 140.00 & 140,00 \\
\hline Yes:ly; Total & & 86881.00 & 73525.00 & 65872.00 & 93778.00 & 12853600 & III061.00 & 103052.00 & 84229.00 & 88362.00 & 70191.00 & 30352.00 & 43332,00 & 29845.00 & 50770.00 & 5180300 & 32092.00 & 32103.00 & 34528.00 & 34238.00 & 34207.00 & 30798.00 \\
\hline
\end{tabular}


Table A.2.Annual Average Tritium Concentrations ( $\mathrm{pCi} / \mathrm{L}$ ) Input to the Two- and Three-Dimensional Transport Models

\begin{tabular}{|c|c|c|c|c|c|c|c|c|c|c|c|c|c|c|c|c|c|c|}
\hline Site & Year & 1979 & 1980 & 1981 & 1982 & 1983 & 1984 & 1985 & 1986 & 1987 & 1988 & 1989 & 1990 & 1991 & 1992 & 1993 & 1994 & 1995 \\
\hline & Year Totals (curies) & 99.58 & 37.447 & 1.81 & 34.85 & 54.07 & 8486.991 & 10918.1 & 7043.53 & 1998.47 & 3388.57 & 183.9 & 5.17 & 24.31 & 2.42 & 14.92 & 5.665 & 0.15 \\
\hline $216-A-8$ & Concentration (pCi/l) & & & & & & 4566 & & & - & & & & & & & & \\
\hline 216-A-8 & Tritium (curies) & 0.78 & & & & & 0.01 & & & & & $\cdot$ & & & & & & \\
\hline $216-A-10$ & Concentration (pCi/l) & & & & & 326546 & 53669512 & 58078788 & 47404167 & 19784500 & 54794521 & 536986 & & 2 & & & & \\
\hline$A-45 \& A-36 B$ & Additional Tritium & & & & & 5.63 & 230.00 & 239.00 & 137.00 & 1559.50 & 2720.00 & 4.90 & & & & & & \\
\hline $216-A-10$ & Tritium (curies) & & & & & 7.60 & 7880.00 & 10000.00 & 6040.00 & 0.31 & & & & & & & & \\
\hline $216-A-25$ & Concentration (pCi/l) & & 100 & & 4035 & 2440 & 4533 & 4433 & & & & & & & & & & \\
\hline 216-A-25 & Tritium (curies) & & 0.99 & & 27.80 & 36.10 & 106.00 & .84 .00 & & & & & & & & & & \\
\hline $216-\Lambda-30$ & Concentration ( $\mathrm{pCi} / \mathrm{l})$ & & & & & 19948 & 271260 & 739962 & 693553 & 250577 & 708922 & 220611 & 2580 & 3011 & & & & \\
\hline A-37-1 \& A-37- & Additional Tritium & & & 0.55 & 6.53 & 4.74 & 129.00 & 550.50 & 561.61 & 154.22 & 297.19 & 117.00 & 0.30 & 0.30 & & & & \\
\hline $216-A-30$ & Tritium (curies) & & & & & & 2.98 & 12.90 & 3.92 & 0.44 & 0.38 & & 0.57 & 0.51 & & & & \\
\hline (Included with & Concentration ( $\mathrm{pC \textrm {i } / \mathrm { l } )}$ & & & & & & & & & & & & & & & & & \\
\hline $216-A-36 B$ & Tritium (curies) & & & & & 5.63 & 230.00 & 239.00 & 137.00 & 39.50 & & & & & & & & \\
\hline (Included with & Concentration (pCi/l) & & & & & & & & & & & & & & & & & \\
\hline $216-A-37-1$ & Tritium (curies) & 42.4 & & 0.55 & 6.53 & 4.74 & 129.00 & 546.00 & 560.00 & 154.00 & 297.00 & 117.00 & & & & & & \\
\hline (Included with & Concentration ( $\mathrm{pC \textrm {i } /} / \mathrm{l})$ & & & & & & & & & & & & & & & & & \\
\hline $216-A-37-2$ & Tritium (curies) & & & & & & & 4.50 & 1.61 & 0.22 & 0.19 & & 0.30 & 0.30 & & & & \\
\hline (Included with & Concentration (pCi/l) & & & & & & & & & & & & & & & & & \\
\hline $216-A-45$ & Tritium (curies) & & & & & & & & & 1520.00 & 2720.00 & 4.90 & & & & & & \\
\hline $216-B-3$ & Concentration (pCi/l) & & & & & & 26173 & 5972 & 13209 & 14445 & 6007 & & 402 & 2333 & 167 & 581 & 786 & 23 \\
\hline 216-B-3 & Tritium (curies) & & & & & & 139.00 & 31.70 & 301.00 & 284.00 & 160.00 & & 4.10 & 21.40 & 1.30 & 3.80 & 5.50 & 0.15 \\
\hline 216-B-55 & Concentration (pCil/) & & 4750 & 21441 & & & 147 & & . & & & & & & & & & \\
\hline 216-B-63 & Additional Tritium & & 0.01 & 1.26 & & & 0.01 & & & & & & & & & & & \\
\hline 216-B-55 & Tritium (curies) & 3.6 & 0.26 & & & & & & & & & & & 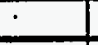 & & & & \\
\hline (Included with & Concentration ( $\mathrm{pCi} / \mathrm{l})$ & & & & & & & & & & & & & & & & & \\
\hline $216-B-62$ & Tritium (curies) & 2.6 & 0.01 & 1.26 & & & 0.01 & & & & & & & & & & & \\
\hline $216-\mathrm{B}-63$ & Concentration ( $\mathrm{pCi} / \mathrm{l})$ & & 1818 & & & & & & & & & & & & & & & \\
\hline $216-B-63$ & Tritium (curies) & 1.8 & 0.59 & & & & & & & & & & & & & & & \\
\hline $216-S-25$ & Concentration (pCi $/ 1)$ & & 9923 & & & & & & & & & & & & & & & \\
\hline $216-S-25$ & Tritium (curies) & 48.4 & 35.60 & & & & & & & & & & & & & & & \\
\hline $216-U-14$ & Concentration (pCi/l) & & & & & & & & & & 698019 & & 871 & 6523 & 2152 & 440 & 864 & \\
\hline $216-U-14$ & Tritium (curies) & & & & & & & & 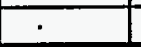 & & 200.00 & & 0.20 & .2 .10 & 0.60 & 0.12 & 0.10 & \\
\hline $216-U-17$ & Concentration (pCi/l) & & $\cdot$ & & & & & & & & 15068493 & 42465753 & & & 474886 & 5022831 & 178082 & \\
\hline $216-U-17$ & Tritium (curies) & & & & & & & & & & 11.00 & 62.00 & & & 0.52 & 11.00 & 0.07 & \\
\hline 216-W-LC & Concentration (pCi/l) & & & & 2907 & & & & & & & & & & & & & \\
\hline $216-W-L C$ & Tritium (curics) & & & & 0.52 & & & & & & & & & & & & & \\
\hline
\end{tabular}




\section{Distribution}

No. of

Copies

\section{OFFSITE}

J. S. Bachmaier

Office of Environmental Policy

and Assistance

U.S. Department of Energy

1000 Independence Ave. SW

Washington. D. C. 20585

N. Buschman

U. S. Department of Energy

EM-20, 1

Clov Room 1105

19901 Germantown Rd.

Germantown, MD 20874

R. A. Danielson

Washington State Departmẹnt of

Health

2 South 45th Ave.

Yakima, WA 98908

B. Drost

U. S. Geological Survey

1201 Pacific Ave., Suite 600

Tacoma, WA 98402

Phil Rogers

Jacobs Engineering, Inc.

2 T. Gilmore

Environmental Planning/

Rights Protection

Confederated Tribes of the

Umatilla Indian Reservation

Hanford Projects

P. O. Box 638

Pendleton, OR 97801
No. of

Copies .

M. Harmon

U.S. Department of Energy

656 Quin Orchard Road

Building QO

Gaithersburg, MD 20585

2 S. Harris

Environmental Restoration/

Waste Management

Nez Perce Tribe

P. O. Box 365

Lapwai, ID 83540-0365

2 R. Jim

Yakama Indian Nation

Environmental Restoration/

Waste Management

P. O. Box 151

Toppenish, Wa 98948

R. Patt

Oregon State Department of

Water Resources

3850 Portland Road

Salem, OR 97310 
No. of

Copies

\section{ONSITE}

\section{DOE Richland Operations Office}

L. K. Bauer

T. W. Ferns

B. L. Foley

M. J. Furman

R. D. Hildebrand (10)

R. A. Holten

P. E. Lamont

R. W. Lober

D. E. Olsen

J. E. Rasmussen

R. M. Rosselli

D. S. Shafer

R. K. Stewart

A. E. Teimouri

K. M. Thompson

A. C. Tortoso

D. M. Wanek

A. K. Wright

8 Bechtel Hanford, Inc.

M. P. Connelly

G. R. Chiaramonte

K. R. Fecht

A. J. Knepp (3)

G. B. Mitchem .

L. C. Swanson

H6-07

H6-01

H4-80

H4-80

H0-17

H6-03

4 U. S: Environmental Protection Agency

L. E. Gadbois

B5-01

D. R. Sherwood (3)

B5-01

3 Washington State Department of Ecology

D. N. Goswami (3)

N1-05

No. of

Copies

56 Pacific Northwest National Laboratory

D. B. Barnett

K6-81

M. P. Bergeron (5) K9-33

R. W. Bryce

K6-96

C. R. Cole (10)

K9-36

J. L. Devary

K9-56

P. E. Dresel

K6-96

M. J. Fayer

K9-33

M. D. Freshley (5)

K9-36

V. G. Johnson

K6-96

S. P. Luttrell (5)

K6-96

J. T. Rieger

K6-96

R. M. Smith

K6-96

P. D. Thorne (5)

K6-96

W. D. Webber (5)

K6-96

M. D. Williams

K9-36

S. K. Wurstner (5)

K9-36

Information Release Office (7) K1-06 